University of Nebraska - Lincoln

DigitalCommons@University of Nebraska - Lincoln

Agronomy \& Horticulture -- Faculty Publications

Agronomy and Horticulture Department

2013

Evaluation of Public Sweet Sorghum A-Lines for Use in Hybrid Production

Jeffrey F. Pedersen

USDA-ARS, jpedersen1@unl.edu

Scott E. Sattler

USDA-ARS, Scott.Sattler@ars.usda.gov

William F. Anderson

USDA-ARS

Follow this and additional works at: https://digitalcommons.unl.edu/agronomyfacpub

Part of the Agricultural Science Commons, Agriculture Commons, Agronomy and Crop Sciences Commons, Botany Commons, Horticulture Commons, Other Plant Sciences Commons, and the Plant Biology Commons

Pedersen, Jeffrey F.; Sattler, Scott E.; and Anderson, William F., "Evaluation of Public Sweet Sorghum ALines for Use in Hybrid Production" (2013). Agronomy \& Horticulture -- Faculty Publications. 685.

https://digitalcommons.unl.edu/agronomyfacpub/685

This Article is brought to you for free and open access by the Agronomy and Horticulture Department at DigitalCommons@University of Nebraska - Lincoln. It has been accepted for inclusion in Agronomy \& Horticulture -Faculty Publications by an authorized administrator of DigitalCommons@University of Nebraska - Lincoln. 


\title{
Evaluation of Public Sweet Sorghum A-Lines for Use in Hybrid Production
}

\author{
Jeffrey F. Pedersen • Scott E. Sattler • William F. \\ Anderson
}

Published online: 8 July 2012

(C) Springer Science+Business Media, LLC (outside the USA) 2012

This article is a U.S. government work, and is not subject to copyright in the United States.

Abstract A fundamental need for commercialization of sweet sorghum [Sorghum bicolor (L.) Moench] as a bioenergy crop is an adequate seed supply, which will require development of hybrid varieties using dwarf seed-parent lines. A set of six public sweet sorghum A-lines (Dwarf

The US Department of Agriculture (USDA) prohibits discrimination in all its programs and activities on the basis of race, color, national origin, age, disability, and where applicable, sex, marital status, familial status, parental status, religion, sexual orientation, genetic information, political beliefs, reprisal, or because all or part of an individual's income is derived from any public assistance program. (Not all prohibited bases apply to all programs.) Persons with disabilities who require alternative means for communication of program information (Braille, large print, audiotape, etc.) should contact USDA's TARGET Center at (202) 720-2600 (voice and TDD). To file a complaint of discrimination, write to USDA, Director, Office of Civil Rights, 1400 Independence Avenue, S.W., Washington, DC 20250-9410, or call (800) 795-3272 (voice) or (202) 720-6382 (TDD). USDA is an equal opportunity provider and employer. Mention of trade names or commercial products in this publication is solely for the purpose of providing specific information and does not imply recommendation or endorsement by the US Department of Agriculture.

Electronic supplementary material The online version of this article (doi:10.1007/s12155-012-9231-1) contains supplementary material, which is available to authorized users.

J. F. Pedersen • S. E. Sattler $(\bowtie)$

USDA-ARS Grain, Forage, and Bioenergy Research Unit,

Lincoln, NE

68583-90937, USA

e-mail: Scott.Sattler@ars.usda.gov

W. F. Anderson

USDA-ARS Crop Genetics and Breeding Research Unit,

115 Coastal Way,

Tifton, GA 31793, USA

J. F. Pedersen · S. E. Sattler

Department of Agronomy and Horticulture,

University of Nebraska,

137 Keim Hall,

Lincoln, NE 68583-90937, USA
Kansas Sourless, KS9, N36, N38, N39, and N4692) were crossed with a set of six public sweet sorghum cultivars (Brawley, Kansas Collier, Dale, Sugar Drip, Waconia, and Wray). Grain, fiber, and sugar yields were determined, and conversion formulas were applied to estimate ethanol yields. Hybrids were grown in fields at Ithaca, NE, USA, in 19831984 fertilized with $112 \mathrm{~kg} \mathrm{ha}^{-1} \mathrm{~N}$. In terms of yield components and overall ethanol yields, one A-line, N38, was inferior. Average total ethanol yields from hybrids made on the other A-lines were not significantly different, suggesting that any of those five A-lines could be useful seed-parents. With the exception of grain yield, cultivars used as pollen parents were among the highest-performing entries for all traits. For all traits directly contributing to total ethanol yield (grain yield, juice yield, \% soluble solids, sugar yield, fiber yield), hybrids were also among the highest-performing entries. Results of this study demonstrate that hybrid sweet sorghum with performance criteria equivalent to existing sweet sorghum cultivars can be produced on the sweet sorghum seed-parent lines A-Dwarf Kansas Sourless, AKS9, A-N36, A-N39, and A-N4692. Identification of specific seed-parent $\times$ pollen parent lines with characteristics best suited for particular growing regions and end-user needs will be critical for commercial hybrid development.

Keywords Sweet sorghum · Hybrid · A-Line · Dwarf · Brix

\section{Introduction}

Sweet sorghum [Sorghum bicolor (L.) Moench] is receiving substantial attention as a bioenergy crop throughout the world [1]. This is primarily due to its potential to produce large quantities of directly harvestable sugars in its juice, which can be readily converted into ethanol through fermentation. In the future, these sugars will potentially be 
converted to "drop-in" biofuels to directly replace specific types of transportation fuels such as diesel or jet fuel. Sweet sorghum is typically tall in stature, with juicy stems containing high levels of sugar. Use of sweet sorghum in bioenergy systems appears particularly attractive in regions already producing sugarcane (Saccharum spp.) because of existing infrastructure for harvest, transport, and processing. In such areas, sweet sorghum can be used to complement sugarcane production by augmenting seasonal voids in harvestable cane and by use in rotations requiring production fields to otherwise be fallowed and non-productive [2]. In more temperate regions, sweet sorghum is being evaluated as a stand-alone crop/bioenergy production system [3].

A fundamental requirement for commercialization of sweet sorghum for bioenergy is an adequate seed supply. To date, most research supporting the potential commercialization of sweet sorghum has utilized open-pollinated varieties such as 'Dale,' 'Della,' 'M81-E,' 'Rio,' 'Theis,' and 'Topper' [4, 5]. Obtaining adequate seed to support relatively small-scale research efforts has at times proven difficult because these tall varieties are prone to lodging and not amenable to mechanical harvest. Large-scale commercialization of sweet sorghum for bioenergy will require substantially larger quantities of seed than is currently produced.

A vibrant commercial sorghum seed industry exists worldwide that has solved large-scale seed production problems through the production of hybrid varieties using dwarf seed-parent lines (A-lines). Height in sorghum is controlled by four major height genes [6] and management of those genes through selection of parents allows production of tall hybrids on dwarf A-lines. Such tall hybrids for use as forage have been produced on dwarf A-lines for decades [7].

Grain sorghums preferentially store carbohydrates in the grain as starch, while sweet sorghums accumulate the carbohydrates in the stem as sugars. There have been recent studies examining the genetic relationships and diversity within the sweet sorghum collections $[8,9]$. However, it will be important to use grain sorghum lines as male sterile A-lines for sufficient production of hybrid seed, and if additive genetic effects control sugar content the A-lines should have genes for free sugars. Ritter et al. [10] reported from their RIL populations that stem sugars are not strongly correlated with grain yield. They also suggest from QTL analysis that sugar-related traits were present from the grain parent as well as the sweet sorghum parent. Murray et al. [11] also found low negative correlation coefficients between grain yield and sugar content and at least one QTL for sugar on the grain parent. This will aid in developing high sugar hybrids. However, Murray et al. [11] point out that the majority of total sugar yield will come from breeding for increased stem fresh weight.

While genetic control of height is relatively well understood, the genetics for free sugar content requires more research. Studies at ICRISAT in India indicated that the likelihood of producing hybrids with high sugar content is influenced by a high-sugar male parent [1]. Sugar content has been reported to be controlled by a single dominant gene $X[6]$, but in practice the sugar content of hybrids is not as predictable as is height. Multiple QTL locations for Brix and sugar content have been observed in other populations [11]. Pfeiffer et al. [12] reported high-parent heterosis for Brix in only one of 12 hybrids, but due to positive heterosis for biomass and juice yield, six had high-parent heterosis for total sugar yield. Additive and dominant gene effects have been determined for increased Brix and sucrose [13]. However, epistasis was also indicated and they concluded that sugar content was controlled by multiple genes. More importantly, heterosis was observed for biomass and total juice yield. These studies along with preliminary results from hybrid trials in Georgia indicate that useful hybrids can be produced from crosses with high Brix tall male lines but that heterosis varies greatly among cross combinations.

Sorghum hybrid seed production relies on the cytoplasmic male sterile line (A-lines), fertility maintainer (B-lines), and fertility restorer (R-lines). A B-line is the pollen source enabling the A-line to produce seed, whose progeny are male sterile, thereby maintaining this trait within the inbred line. Crossing an A-line to an R-line (pollen source) restores fertility in progeny, allowing for the production of fully fertile F1 hybrids. Screening of germplasm and development of new sweet sorghum A-lines are objectives for breeding programs. However, such efforts require, at minimum, multiple generations of backcrossing to convert tall sweet lines into dwarf sweet photo-period insensitive lines and then additional generations of backcrossing to convert fully fertile fertility maintainer (B-lines) into cytoplasmic male sterile lines (A-lines) for use in commercial hybrid production [14].

There is need for developing the capacity to deliver feedstocks to new bioenergy plants. Bioenergy companies are "racing" to construct next-generation plants [15]. The US Twenty in Ten initiative requires 35 billion gallons of renewable and alternative fuels by 2017 [16] —only 5 years away. Delivery of feedstock to refinery gates within a 5-year time-frame essentially precludes development of new sweet sorghum A-lines for first-generation sweet sorghum hybrids and requires utilization of existing A-lines such as ATx623 [17]. While acknowledging that some industries and universities may be developing new sweet sorghum A-lines, previously publicly released sweet sorghum A-lines will likely be utilized in direct production of first-generation sweet sorghum hybrids.

To support that effort, we have compiled data from a previously unpublished 1983-1984 study describing the grain, fiber, and sugar yields of hybrids produced on a set of six public sweet sorghum A-lines and applied current 
ethanol conversion formulas to estimate ethanol yields. Resulting data were analyzed to identify A-lines producing the highest mean and individual hybrid yields when crossed with a set of six public sweet sorghum cultivars.

\section{Materials and Methods}

Five tall but purported 3-dwarf $\left(d w_{1} D w_{2} d w_{3} d w_{4}\right)$ sorghum parental lines male sterilized in $\mathrm{A}_{1}$ male sterile cytoplasm (A-Dwarf Kansas Sourless, A-KS9, A-N36, A-N38, A-N39) $[18,19]$ and the short-statured 2-dwarf $\left(d w_{1} D w_{2} D w_{3} d w_{4}\right)$ A-N4692 (HA 4692; PI 552849) [20, 21] (also male sterilized in $\mathrm{A}_{1}$ male sterile cytoplasm) were each crossed to six sweet sorghum cultivars (Brawley [22], PI 533998, $D w_{1} D w_{2} d w_{3} d w_{4}$; Kansas Collier [23], PI 586540; Dale, PI 651495 [24]; Sugar Drip [23], PI 655983; Waconia [23], PI 641849; and Wray, PI 653616 [25]) to generate $36 \mathrm{~F}_{1}$ hybrids. PI numbers are the identifier from the National Plant Germplasm System (http://www.ars-grin.gov/npgs/ searchgrin.html). The 36 hybrids and six sweet sorghum cultivars used as pollen parents were grown in field trials conducted at Ithaca, NE, USA, on a non-irrigated site in 1983 and 1984. Plots were single rows of $7.6 \mathrm{~m}$ in length and spaced $76 \mathrm{~cm}$ apart. The site was fertilized with $112 \mathrm{~kg} \mathrm{ha}^{-1} \mathrm{~N}$ prior to planting and was treated with $4.2 \mathrm{~kg} \mathrm{ha}^{-1}$ propachlor [2-chloro- $N$-phenylacetamide] and $1.4 \mathrm{~kg} \mathrm{ha}^{-1}$ atrazine [6-chloro- $n$-ethyl- $N$ '-(1-methylethyl)1,3,5-triazine-2,4,dimine] after planting. Plots were planted on 27 May 1983 and 16 May 1984 with excess seed and hand-thinned to a spacing of approximately $15 \mathrm{~cm}$. Flowering date was recorded at $50 \%$ anthesis. Height was measured from the ground to the top of the visually average panicle at maturity. To determine fertility restoration in the F1 hybrids, three panicles were covered with pollinating bags prior to anthesis for each plot and estimated percent fertility was scored visually at maturity. Because there was a large sorghum breeding program (grain, forage, sweet) at the location with a range of maturities during the field trials, there was ample pollen available from other test plots to open-pollinate the Waconia hybrids, which were determined to be male sterile under the pollinating bags. Lodging was visually scored immediately prior to harvest with a score of $1=$ no lodging and a score of $10=$ complete lodging. On 4 October 1983 and 12 September 1984, five random plants were harvested from each plot, juice was squeezed from the fifth internode using a pliers, and \% Brix was recorded using hand-held refractometer. The first killing frost occurred on 23 September 1983 and 26 September 1984.

A $4.57-\mathrm{m}$ section was harvested from each plot from 30 September to 4 October 1983 and from 24 September to 26 September 1984. The heads were removed, dried, and threshed, and grain yield was determined on a dry matter basis. Residual biomass was weighed, and a subsample was dried to determine moisture content. A subsample of approximately $10 \%$ of the stalks with attached leaves was pressed with a roller press to extract juice. The weight of the juice was used to calculate total juice yield. Brix was recorded on a sample of the juice using a hand-held refractometer. To determine sugars gravimetrically ( $\%$ soluble solids), $10 \mathrm{ml}$ of juice was weighed and dried, and the dry residue was weighed to determine \% soluble solids in the juice fraction and soluble solids yield (gravitometric). The remaining fiber was weighed following pressing, and a subsample was dried to determine moisture content for calculation of fiber dry matter yield.

Estimated ethanol yields for each fraction (grain, juice, and fiber) were calculated by multiplying grain, soluble solids in the juice, and bagasse by conversion factors: ethanol yield from grain $=$ grain yield/2.40 [26], ethanol yield from juice $=$ soluble solids (assumed to be hexose sugars) $/$ 1.70 [5], ethanol yield from fiber $=$ fiber yield/2.65 [5]. All estimated ethanol yields were based on the theoretical conversion to ethanol, including an $80 \%$ estimated conversion efficiency [27].

The experimental design was a randomized complete block with three replications in each year. The data were analyzed using the PROC MIXED procedure of SAS/STAT software ${ }^{\circledR}{ }^{1}$ (SAS, 2002-2008). Years and replications were considered as random variables. Data were first analyzed as a $6 \times 6$ factorial with A-lines, sweet sorghum cultivars were used as pollinators, and their interaction was included in the model to generate and compare least square means for Alines for most reported traits and to generate and compare least square means for sweet sorghum cultivars used as pollinators for fertility of their progeny. Data were then analyzed considering all 36 hybrids and the six cultivars used as pollinators as a single treatment to generate and compare least square means for hybrids and sweet sorghum cultivars. For all analyses, the ADJUST = SIMULATE option was used in the LSMEANS/DIFF statement to control type I error and to permit multiple comparisons without the requirement for F-test significance [28]. The rejection level for tests of significance among means was set at $P \leq 0.20$ as recommended by FAO [29] to control and achieve a better balance between type I and type II error rates for experiments such as large variety trials. Entries with means not significantly different from the highest or lowest entry were identified.

Simple correlations were calculated for \% Brix of juice squeezed from the fifth internode of five random plants, \% Brix of juice from the whole plot sample, and \% soluble

\footnotetext{
${ }^{1}$ SAS and all other SAS Institute Inc. product or service names are registered trademarks or trademarks of SAS Institute Inc. in the USA and other countries. ${ }^{\circledR}$ indicates USA registration.
} 
solids determined gravimetrically from juice from the whole plot sample. Lastly, regressions were run using the MAXR Model in the PROC REG procedure of SAS/STAT software to determine the "best" single-trait model, two-trait model, three-trait model, etc., for prediction of total ethanol from juice yield, $\%$ solids from 20-plant samples, grain yield, fiber yield, days to $50 \%$ anthesis, and plant height. Maximum $R^{2}$ and Mallow's Cp statistic output were used to determine "best" models.

In general, the cultivation practices have not significantly changed terms in of planting depths, row spacing, herbicide applications, and fertilizer amendments from 1983-1984 to the present. Plots are no longer hand-thinned, and often plots are three rows where the middle row is harvested for studies. Climatically, the environment has not changed dramatically since 1983-1984 to present. Sorghum is still planted around the third week of May in Nebraska and typical frost dates range from end of September to mid-October. We have enclosed the month weather date data taken on the field site and provided by NOAA from 1983 to 2011 (File 1 of "Electronic supplementary material"). The summer of 1983 appeared warmer than average and 1984 was nearly average.

\section{Results}

\section{Average A-Line Performance in Hybrid Combination}

Statistically significant differences in height, days to $50 \%$ anthesis, and lodging were attributable to A-lines (Table 1). Average heights of resulting hybrids ranged from $207 \mathrm{~cm}$ for N38 hybrids to $227 \mathrm{~cm}$ for Dwarf Kansas Sourless hybrids. Days to heading ranged from 73 for N38 to 77 for Dwarf Kansas Sourless. Using a visual score of $1=$ no lodging to $10=$ complete lodging, lodging ranged from 3.4 for N38 to 4.5 for N39.
Average grain yield was highest on hybrids made on N36, N38, N39, and N4692 and ranging from 5,055 kg/ha for Dwarf Kansas Sourless to $5,893 \mathrm{~kg} / \mathrm{ha}$ for N38. Sugar yield, influenced by both juice yield and \% soluble solids, was highest for hybrids made on Dwarf Kansas Sourless, KS9, N36, and N4692 and ranged from 1,978 kg/ha for N38 to $2,655 \mathrm{~kg} / \mathrm{ha}$ for Dwarf Kansas Sourless. Fiber yield was statistically similar for hybrids made on most A-lines with the exception of N38 hybrids having a significantly different (lower) fiber yield than all hybrids from other A-lines. Fiber yields ranged from $13,561 \mathrm{~kg} /$ ha for $\mathrm{N} 38$ to $17,175 \mathrm{~kg} / \mathrm{ha}$ for Dwarf Kansas Sourless (Table 1).

Ethanol yield from grain, juice, and fiber followed the same trends as dry matter yield from grain, sugar, and fiber. Total ethanol yields were similar for hybrids averaged across A-lines with only N38 being significantly different (lower) in terms of total ethanol yields than hybrids from other A-lines. Total ethanol yields ranged from 8,736 L/ha for N38 to $10,206 \mathrm{~L} /$ ha for N4692 (Table 1).

\section{Fertility Restoration in the $\mathrm{F}_{1}$ Hybrids}

Hybrids made using the six sweet sorghum varieties included in this study exhibited wide divergence in self-fertility and separated into four different $(P \leq 0.20)$ groupings: Dale and Wray hybrids averaged $98.2 \%$ seed set under pollinating bags. Brawley hybrids averaged $71 \%$ seed set under pollinating bags. Kansas Collier and Sugar Drip averaged 29.1\% seed set under pollinating bags. Waconia averaged $1.2 \%$ seed set under pollinating bags. Although the A-line $\times$ pollinator-line interaction was significant for self-fertility, individual hybrid (A-line $\times$ Pollinator-line) self-fertility values offered no additional biological insights and are therefore not reported.

Table 1 Average agronomic performance, component yield, and calculated ethanol yields from hybrids produced on six sweet sorghum seedparent lines

\begin{tabular}{|c|c|c|c|c|c|c|c|c|c|c|c|c|}
\hline \multirow[t]{2}{*}{ A-line } & \multirow{2}{*}{$\begin{array}{l}\text { Height } \\
\overline{\mathrm{cm}}\end{array}$} & \multirow{2}{*}{$\begin{array}{l}\text { Days to } 50 \% \\
\text { anthesis } \\
\text { days }\end{array}$} & \multirow[t]{2}{*}{ Lodging $^{\mathrm{a}}$} & \multirow{2}{*}{$\begin{array}{l}\text { Grain } \\
\text { yield }\end{array}$} & \multirow[t]{2}{*}{$\begin{array}{l}\text { Juice } \\
\text { yield }\end{array}$} & \multirow{2}{*}{$\begin{array}{l}\begin{array}{l}\text { Soluble } \\
\text { solids }\end{array} \\
\%\end{array}$} & \multirow{2}{*}{$\begin{array}{l}\begin{array}{l}\text { Sugar } \\
\text { yield }\end{array} \\
\mathrm{kg} / \mathrm{ha}\end{array}$} & \multirow[t]{2}{*}{$\begin{array}{l}\text { Fiber } \\
\text { yield }\end{array}$} & \multirow{2}{*}{$\begin{array}{l}\text { Ethanol } \\
\text { from grain } \\
\mathrm{L} / \mathrm{ha}\end{array}$} & \multirow[t]{2}{*}{$\begin{array}{l}\text { Ethanol } \\
\text { from juice }\end{array}$} & \multirow[t]{2}{*}{$\begin{array}{l}\text { Ethanol } \\
\text { from fiber }\end{array}$} & \multirow[t]{2}{*}{$\begin{array}{l}\text { Ethanol } \\
\text { total }\end{array}$} \\
\hline & & & & & & & & & & & & \\
\hline DKS & $227 \mathrm{a}$ & $77 \mathrm{a}$ & $4.3 \mathrm{ab}$ & $5,055 \mathrm{~b}$ & 16,909 a & $15.9 \mathrm{abc}$ & $2,655 \mathrm{a}$ & $17,175 \mathrm{a}$ & $2,106 \mathrm{~b}$ & $1,562 \mathrm{a}$ & $6,481 \mathrm{a}$ & $10,146 \mathrm{a}$ \\
\hline KS9 & $213 \mathrm{c}$ & $74 \mathrm{c}$ & $3.6 \mathrm{bc}$ & $5,282 \mathrm{~b}$ & $16,179 \mathrm{a}$ & $16.3 \mathrm{ab}$ & $2,603 \mathrm{a}$ & $16,798 \mathrm{ab}$ & $2,201 \mathrm{~b}$ & $1,531 \mathrm{a}$ & $6,339 \mathrm{ab}$ & $10,071 \mathrm{a}$ \\
\hline N36 & $212 \mathrm{c}$ & $76 a b$ & $3.9 \mathrm{abc}$ & $5,691 \mathrm{a}$ & $15,565 \mathrm{a}$ & $16.5 \mathrm{a}$ & $2,516 \mathrm{a}$ & $15,847 \mathrm{~b}$ & $2,371 \mathrm{a}$ & $1,480 \mathrm{a}$ & $5,980 \mathrm{~b}$ & $9,831 \mathrm{a}$ \\
\hline N38 & $207 \mathrm{~d}$ & $73 \mathrm{c}$ & $3.4 \mathrm{c}$ & $5,893 \mathrm{a}$ & $13,214 \mathrm{~b}$ & $15.2 \mathrm{bc}$ & $1,978 \mathrm{c}$ & $13,561 \mathrm{c}$ & $2,455 \mathrm{a}$ & $1,164 \mathrm{c}$ & $5,117 \mathrm{c}$ & $8,736 \mathrm{~b}$ \\
\hline N39 & $215 \mathrm{bc}$ & $75 \mathrm{~b}$ & $4.5 \mathrm{a}$ & $5,703 \mathrm{a}$ & $15,726 \mathrm{a}$ & $14.8 \mathrm{c}$ & $2,263 \mathrm{~b}$ & $15,705 \mathrm{~b}$ & $2,376 \mathrm{a}$ & $1,331 \mathrm{~b}$ & $5,926 \mathrm{~b}$ & 9,631 \\
\hline N4692 & $220 \mathrm{~b}$ & $74 \mathrm{c}$ & $4.4 \mathrm{a}$ & 5,806 a & $16,836 \mathrm{a}$ & $15.4 \mathrm{abc}$ & $2,518 \mathrm{a}$ & $16,710 \mathrm{ab}$ & $2,419 \mathrm{a}$ & $1,481 \mathrm{a}$ & $6,305 \mathrm{ab}$ & 10,206 \\
\hline
\end{tabular}

Means in the same column followed by the same letter are not significantly different at $P=0.20$ (see explanation in "Materials and Methods" for further details)

DKS Dwarf Kansas Sourless

${ }^{\text {a }}$ Visual score with $1=$ no lodging and $10=$ complete lodging 
Performance of Individual Hybrids and Sweet Sorghum Varieties

Hybrids and sweet sorghum varieties ranged from 178 to $257 \mathrm{~cm}$ in height (Table 2). Considering all possible paired comparisons for hybrids and sweet sorghum varieties, Dale, Brawley, Sugar Drip, and the Dwarf Kansas Sourless $\times$ Dale hybrid were not different from each other in height and were taller than all other varieties or hybrids $(P \leq 0.20)$. Four hybrids involving Waconia, KS9 $\times$ Waconia, N36 $\times$ Waconia, N38 $\times$ Waconia, and N39 $\times$ Waconia, were not different from each other and were shorter than all other varieties or hybrids.

Time from planting to $50 \%$ anthesis ranged from 65 to 93 days (Table 2). The latest maturing entries were the sweet sorghum varieties Dale and Wray. Lodging scores $(1=$ no lodging and $10=$ complete lodging) ranged from 1.5 to 6.7 (Table 2). Hybrids and sweet sorghum varieties were both among the group of entries with lowest lodging scores and the group of entries with highest lodging scores.

Grain yield ranged from 1,086 to $6,647 \mathrm{~kg} / \mathrm{ha}$ (Table 2), with clear statistical discrimination between the lowest- and highest-yielding entries. All entries in the group with highest grain yields were hybrids. All entries in the group with lowest grain yields were varieties. Results for ethanol yield from grain separated into the same statistically discriminate groupings and ranged from 452 to $2,770 \mathrm{~L} /$ ha (Table 2).

Juice yields ranged from 11,040 to $20,841 \mathrm{~kg} / \mathrm{ha}$ (Table 3 ). Some high and low values were statistically different from each other. Intermediate juice yields were not different from the highest or lowest yields. Percent soluble solids ranged from 13.1 to $19.2 \%$ (Table 3 ), but few entry means differed from each other at $P \leq 0.20$. The only entries with percent soluble solids means not among the group of means with the lowest values were Wray (19.2\%), Kansas Collier (18.8\%), Waconia (18.7\%), and hybrid N36 × Sugar Drip (18.3\%). The only entries with percent soluble solids means not among the highest values were the hybrids N39 × Dale (13.1\%), N39 $\times$ Brawley, and N38 $\times$ Waconia $(14.0 \%)$. Sugar yield is a function of both juice yield and \% soluble solids and ranged from 1,558 to $3,881 \mathrm{~kg} /$ ha (Table 3 ). Sugar yield showed a higher level of statistical discrimination among means than either juice yields or percent soluble solids alone. Entries with highest sugar yields included the varieties Kansas Collier (3,315 kg/ha), Sugar Drip (3,611 kg/ha), and Wray $(3,881 \mathrm{~kg} / \mathrm{ha})$ and the hybrids Dwarf Kansas Sourless $\times$ Wray $(3,246 \mathrm{~kg} / \mathrm{ha}), \mathrm{KS} 9 \times$ Dale $(3,035 \mathrm{~kg} / \mathrm{ha})$, and N36 $\times$ Wray $(3,064 \mathrm{~kg} / \mathrm{ha})$. No sweet sorghum varieties were among the group with lowest sugar yields. Ethanol yields from juice separated into the same statistically discriminate groupings as sugar yield and ranged from 916 to $2,283 \mathrm{~L} / \mathrm{ha}$ (Table 3).

Fiber yields ranged from 10,872 to $24,101 \mathrm{~kg} /$ ha (Table 4). The varieties Dale, Sugar Drip, and Wray (18,987, 24,101, and
$22,242 \mathrm{~kg} / \mathrm{ha}$, respectively) and five hybrids (ranging from 18,963 to $20,892 \mathrm{~kg} / \mathrm{ha}$ ) had fiber yields significantly different from the lowest-yielding entries. Ethanol yields from fiber ranged from 4,103 to 9,095 L/ha (Table 4) and separated into the same statistically discriminate groupings as fiber yield.

Total ethanol yields ranged from 7,232 to $12,394 \mathrm{~L} / \mathrm{ha}$ (Table 4). Entries means statistically different from the lowest-yielding means included the cultivars Kansas Collier, Sugar Drip, and Wray $(9,842,12,394$, and 11,136 L/ha, respectively) and 17 hybrids (ranging from 9,867 to $12,071 \mathrm{~L} / \mathrm{ha}$ ).

Correlation of Estimates of \% Solids

Percent Brix of juice squeezed from the fifth internode of a five-plant subsample of the plot in the field was a less reliable predictor of $\%$ solids in juice squeezed from $10 \%$ of the plot ( $\sim 20$ plants) sample utilizing a roller press and total stalks and leaves. Pearson's correlation coefficient for these two traits was only 0.67 (Table 5). Pearson's correlation coefficient for $\%$ Brix of juice from the 20-plant sample and $\%$ solids was 0.90 .

\section{Traits Contributing Most Strongly to Ethanol Yield}

Total ethanol yield was predicted very well using only fiber yield in a single variable model $\left(R^{2}=0.9139\right)$ (Table 6). Adding grain yield to generate a two-factor model increased the $R^{2}$ to 0.9697 and reduced Mallow's Cp from 14,692 to 5,011. Adding \% solids to generate a three-factor model increased $R^{2}$ to 0.9859 and reduced Mallow's Cp to 2,205. Adding percent juice yield to generate a four-factor model increased $R^{2}$ to 0.9986 and reduced Mallow's $\mathrm{Cp}$ to 7. Adding height and days to heading had no further effect on $R^{2}$ and little effect on Mallow's Cp.

\section{Discussion}

Average A-Line Performance in Hybrid Combination

The clear discrimination among average performance values for height and days to $50 \%$ anthesis has practical implications for potential use of the A-lines evaluated in this study as potential parents for hybrid production. Dwarf Kansas Sourless would be expected to produce longer-season and taller hybrids that the other A-lines. N38 would be expected to produce shorter-stature and shorter-season hybrids. Although there was statistical discrimination, all A-lines produced hybrids with intermediate potential for lodging. None of the crosses showed heterosis for height or $50 \%$ anthesis. Other crossing populations have consistently found high parent heterosis for plant height in hybrids [12, 13] and over-dominance in RILs $[10,30]$. The difference in results 
Table 2 Height, days to $50 \%$ anthesis, lodging scores, grain yield, and calculated ethanol yields from grain for six sweet sorghum varieties and 36 sweet sorghum hybrids

\begin{tabular}{|c|c|c|c|c|c|c|c|c|c|c|}
\hline \multirow[t]{2}{*}{ Entry } & \multicolumn{2}{|c|}{ Height } & \multicolumn{2}{|c|}{ Days to $50 \%$ anthesis } & \multicolumn{2}{|c|}{ Lodging } & \multicolumn{2}{|c|}{ Grain yield } & \multicolumn{2}{|c|}{ Ethanol from grain } \\
\hline & $\mathrm{cm}$ & & days & & Score & & $\mathrm{kg} / \mathrm{ha}$ & & $\mathrm{L} / \mathrm{ha}$ & \\
\hline Brawley & 253 & $a$ & 79 & & 5.8 & $a$ & 3,598 & & 1,499 & \\
\hline Dale & 257 & $a$ & 96 & $a$ & 6.3 & $a$ & 1,086 & $b$ & 452 & $b$ \\
\hline Kansas Collier & 226 & & 76 & & 3.0 & $b$ & 2,896 & & 1,207 & \\
\hline Sugar Drip & 252 & $a$ & 87 & & 3.0 & $b$ & 2,820 & & 1,175 & \\
\hline Waconia & 221 & & 72 & & 5.0 & $a$ & 3,512 & & 1,463 & \\
\hline Wray & 233 & & 93 & $a$ & 6.7 & $a$ & 1,103 & $b$ & 460 & $b$ \\
\hline Dwarf Kansas Sourless $\times$ Brawley & 232 & & 76 & & 4.6 & $\mathrm{ab}$ & 4,925 & & 2,052 & \\
\hline Dwarf Kansas Sourless $\times$ Dale & 246 & a & 84 & & 4.5 & $\mathrm{a}$ & 5,031 & & 2,096 & \\
\hline Dwarf Kansas Sourless $\times$ Kansas Collier & 220 & & 73 & & 4.3 & $\mathrm{ab}$ & 5,246 & & 2,186 & \\
\hline Dwarf Kansas Sourless $\times$ Sugar Drip & 217 & & 79 & & 3.0 & $\mathrm{~b}$ & 4,051 & & 1,688 & \\
\hline Dwarf Kansas Sourless $\times$ Waconia & 213 & & 70 & $\mathrm{~b}$ & 4.5 & a & 5,358 & a & 2,232 & a \\
\hline Dwarf Kansas Sourless $\times$ Wray & 236 & & 79 & & 4.7 & a & 5,733 & $\mathrm{a}$ & 2,389 & a \\
\hline KS9 $\times$ Brawley & 218 & & 72 & & 5.3 & $\mathrm{a}$ & 5,139 & & 2,141 & \\
\hline KS9 $\times$ Dale & 228 & & 80 & & 6.2 & $\mathrm{a}$ & 5,769 & $\mathrm{a}$ & 2,404 & $\mathrm{a}$ \\
\hline KS9 $\times$ Kansas Collier & 209 & & 72 & $\mathrm{~b}$ & 2.3 & $\mathrm{~b}$ & 6,451 & $\mathrm{a}$ & 2,688 & $\mathrm{a}$ \\
\hline KS9 $\times$ Sugar Drip & 212 & & 79 & & 2.3 & $\mathrm{~b}$ & 4,856 & & 2,023 & \\
\hline KS9 $\times$ Waconia & 178 & $\mathrm{~b}$ & 66 & $\mathrm{~b}$ & 1.8 & $\mathrm{~b}$ & 3,999 & & 1,666 & \\
\hline KS9 $\times$ Wray & 233 & & 76 & & 3.7 & $\mathrm{~b}$ & 5,481 & $\mathrm{a}$ & 2,284 & $\mathrm{a}$ \\
\hline N36 $\times$ Brawley & 221 & & 75 & & 4.7 & a & 5,934 & $\mathrm{a}$ & 2,473 & $\mathrm{a}$ \\
\hline N36 $\times$ Dale & 226 & & 82 & & 4.3 & $\mathrm{ab}$ & 6,144 & $\mathrm{a}$ & 2,560 & $\mathrm{a}$ \\
\hline N36 $\times$ Kansas Collier & 212 & & 73 & & 4.8 & $\mathrm{a}$ & 6,181 & $\mathrm{a}$ & 2,575 & $\mathrm{a}$ \\
\hline N36 × Sugar Drip & 204 & & 79 & & 2.3 & $\mathrm{~b}$ & 4,902 & & 2,043 & \\
\hline N36 × Waconia & 190 & $\mathrm{~b}$ & 68 & $\mathrm{~b}$ & 2.5 & $\mathrm{~b}$ & 5,056 & & 2,107 & \\
\hline N36 × Wray & 221 & & 79 & & 4.5 & a & 5,932 & $\mathrm{a}$ & 2,472 & $\mathrm{a}$ \\
\hline $\mathrm{N} 38 \times$ Brawley & 215 & & 71 & & 4.0 & $\mathrm{ab}$ & 5,797 & $\mathrm{a}$ & 2,415 & a \\
\hline N38 $\times$ Dale & 223 & & 80 & & 3.7 & $\mathrm{~b}$ & 5,902 & $\mathrm{a}$ & 2,459 & $\mathrm{a}$ \\
\hline N38 $\times$ Kansas Collier & 213 & & 72 & & 6.0 & a & 5,719 & $\mathrm{a}$ & 2,383 & $\mathrm{a}$ \\
\hline N38 × Sugar Drip & 198 & & 77 & & 1.5 & $\mathrm{~b}$ & 5,912 & $\mathrm{a}$ & 2,463 & a \\
\hline N38 $\times$ Waconia & 180 & $\mathrm{~b}$ & 67 & $\mathrm{~b}$ & 1.8 & $\mathrm{~b}$ & 5,472 & $\mathrm{a}$ & 2,280 & $\mathrm{a}$ \\
\hline N38 × Wray & 213 & & 72 & & 3.3 & $\mathrm{~b}$ & 6,554 & a & 2,731 & a \\
\hline N39 $\times$ Brawley & 213 & & 70 & & 5.7 & a & 6,012 & a & 2,505 & a \\
\hline N39 $\times$ Dale & 225 & & 84 & & 4.0 & $a b$ & 5,285 & $\mathrm{a}$ & 2,202 & a \\
\hline N39 $\times$ Kansas Collier & 221 & & 72 & & 4.8 & a & 5,836 & a & 2,432 & a \\
\hline N39 × Sugar Drip & 218 & & 79 & & 2.5 & $\mathrm{~b}$ & 4,945 & & 2,060 & \\
\hline N39 $\times$ Waconia & 189 & $\mathrm{~b}$ & 69 & $\mathrm{~b}$ & 4.5 & a & 5,507 & $\mathrm{a}$ & 2,295 & a \\
\hline N39 × Wray & 227 & & 78 & & 5.5 & a & 6,647 & $\mathrm{a}$ & 2,770 & $\mathrm{a}$ \\
\hline N4692 × Brawley & 230 & & 70 & & 5.3 & $\mathrm{a}$ & 6,021 & $\mathrm{a}$ & 2,509 & $\mathrm{a}$ \\
\hline N4692 $\times$ Dale & 239 & & 82 & & 4.8 & a & 5,861 & a & 2,442 & a \\
\hline N4692 $\times$ Kansas Collier & 211 & & 70 & & 4.3 & $a b$ & 6,414 & $\mathrm{a}$ & 2,673 & $\mathrm{a}$ \\
\hline N4692 × Sugar Drip & 223 & & 79 & & 3.8 & $a b$ & 4,846 & & 2,019 & \\
\hline N4692 × Waconia & 189 & $\mathrm{~b}$ & 65 & $\mathrm{~b}$ & 2.3 & $\mathrm{~b}$ & 5,343 & a & 2,226 & a \\
\hline N4692 × Wray & 225 & & 76 & & 5.8 & $\mathrm{a}$ & 6,350 & $\mathrm{a}$ & 2,646 & $\mathrm{a}$ \\
\hline
\end{tabular}

${ }^{\mathrm{a}}$ Visual score with $1=$ no lodging and $10=$ complete lodging

Varietal results are shown in rows with italicized entries for convenience. Means in the same column followed by letter "a" are not significantly different from the highest value at $P=0.20$. Means in the same column followed by letter "b" are not significantly different from the lowest value at $P=0.20$ (see explanation in "Materials and Methods" for further details) 
Table 3 Juice yields, soluble sugar content, and calculated sugar and ethanol yields for six sweet sorghum varieties and 36 sweet sorghum hybrids

\begin{tabular}{|c|c|c|c|c|c|c|c|c|}
\hline \multirow[t]{2}{*}{ Entry } & \multicolumn{2}{|c|}{ Juice yield } & \multicolumn{2}{|c|}{ Soluble solids } & \multicolumn{2}{|c|}{ Sugar yield } & \multicolumn{2}{|c|}{ Ethanol yield from sugar } \\
\hline & $\mathrm{kg} / \mathrm{ha}$ & & $\%$ & & $\mathrm{~kg} / \mathrm{ha}$ & & $\mathrm{L} / \mathrm{ha}$ & \\
\hline Brawley & 17,053 & $a$ & 17.4 & $a b$ & 2,926 & & 1,721 & \\
\hline Dale & 17,068 & $a$ & 17.3 & $a b$ & 2,845 & & 1,673 & \\
\hline Kansas Collier & 17,574 & $a$ & 18.8 & $a$ & 3,315 & $a$ & 1,950 & $a$ \\
\hline Sugar Drip & 20,841 & $a$ & 17.5 & $a b$ & 3,611 & $a$ & 2,124 & $a$ \\
\hline Waconia & 14,538 & $b$ & 18.7 & $a$ & 2,700 & & 1,588 & \\
\hline Wray & 20,278 & $a$ & 19.2 & $a$ & 3,881 & $a$ & 2,283 & $a$ \\
\hline Dwarf Kansas Sourless $\times$ Brawley & 17,797 & $\mathrm{a}$ & 14.7 & $a b$ & 2,575 & & 1,515 & \\
\hline Dwarf Kansas Sourless $\times$ Dale & 16,566 & $a b$ & 14.8 & $a b$ & 2,435 & $\mathrm{~b}$ & 1,432 & $\mathrm{~b}$ \\
\hline Dwarf Kansas Sourless $\times$ Kansas Collier & 14,906 & $\mathrm{~b}$ & 17 & $a b$ & 2,402 & $\mathrm{~b}$ & 1,413 & $\mathrm{~b}$ \\
\hline Dwarf Kansas Sourless $\times$ Sugar Drip & 16,995 & a & 16.2 & $a b$ & 2,747 & & 1,616 & \\
\hline Dwarf Kansas Sourless $\times$ Waconia & 15,402 & $a b$ & 16.5 & $a b$ & 2,513 & & 1,478 & \\
\hline Dwarf Kansas Sourless $\times$ Wray & 19,768 & $\mathrm{a}$ & 16.4 & $a b$ & 3,246 & a & 1,909 & a \\
\hline KS9 $\times$ Brawley & 14,126 & $\mathrm{~b}$ & 16.7 & $a b$ & 2,366 & $\mathrm{~b}$ & 1,392 & $\mathrm{~b}$ \\
\hline KS9 $\times$ Dale & 18,271 & $\mathrm{a}$ & 17 & $a b$ & 3,035 & $\mathrm{a}$ & 1,785 & a \\
\hline KS9 $\times$ Kansas Collier & 16,359 & $a b$ & 16.2 & $\mathrm{ab}$ & 2,607 & & 1,533 & \\
\hline KS9 $\times$ Sugar Drip & 16,746 & $a b$ & 17.4 & $\mathrm{ab}$ & 2,875 & & 1,691 & \\
\hline KS9 × Waconia & 12,276 & $\mathrm{~b}$ & 15.8 & $a b$ & 1,941 & $\mathrm{~b}$ & 1,142 & $\mathrm{~b}$ \\
\hline KS9 × Wray & 19,295 & $\mathrm{a}$ & 14.5 & $\mathrm{ab}$ & 2,793 & & 1,643 & \\
\hline N36 × Brawley & 16,240 & $\mathrm{ab}$ & 16.2 & $\mathrm{ab}$ & 2,607 & & 1,534 & \\
\hline N36 × Dale & 16,006 & $a b$ & 15 & $\mathrm{ab}$ & 2,204 & $\mathrm{~b}$ & 1,296 & $\mathrm{~b}$ \\
\hline N36 × Kansas Collier & 14,106 & $\mathrm{~b}$ & 15.8 & $a b$ & 2,197 & $\mathrm{~b}$ & 1,292 & $\mathrm{~b}$ \\
\hline N36 × Sugar Drip & 16,064 & $a b$ & 18.3 & $\mathrm{a}$ & 2,883 & & 1,696 & \\
\hline N36 $\times$ Waconia & 13,268 & $\mathrm{~b}$ & 16.2 & $a b$ & 2,141 & $\mathrm{~b}$ & 1,259 & $\mathrm{~b}$ \\
\hline N36 × Wray & 17,706 & $\mathrm{a}$ & 17.5 & $a b$ & 3,064 & $\mathrm{a}$ & 1,802 & a \\
\hline $\mathrm{N} 38 \times$ Brawley & 14,512 & $\mathrm{~b}$ & 16.1 & $a b$ & 2,355 & $\mathrm{~b}$ & 1,385 & $\mathrm{~b}$ \\
\hline N38 $\times$ Dale & 14,835 & $\mathrm{~b}$ & 14.8 & $a b$ & 2,078 & $\mathrm{~b}$ & 1,222 & $\mathrm{~b}$ \\
\hline N38 $\times$ Kansas Collier & 12,141 & $\mathrm{~b}$ & 15.3 & $a b$ & 1,779 & $\mathrm{~b}$ & 1,047 & $\mathrm{~b}$ \\
\hline N38 × Sugar Drip & 12,486 & $\mathrm{~b}$ & 16.2 & $a b$ & 2,037 & $\mathrm{~b}$ & 1,198 & $\mathrm{~b}$ \\
\hline $\mathrm{N} 38 \times$ Waconia & 11,040 & $\mathrm{~b}$ & 14 & $\mathrm{~b}$ & 1,558 & $\mathrm{~b}$ & 916 & $\mathrm{~b}$ \\
\hline N38 × Wray & 14,270 & $\mathrm{~b}$ & 14.5 & $a b$ & 2,063 & $\mathrm{~b}$ & 1,214 & $\mathrm{~b}$ \\
\hline N39 × Brawley & 14,743 & $\mathrm{~b}$ & 13.9 & $\mathrm{bb}$ & 2,023 & $\mathrm{~b}$ & 1,190 & $\mathrm{~b}$ \\
\hline $\mathrm{N} 39 \times$ Dale & 18,245 & $\mathrm{a}$ & 13.1 & $\mathrm{~b}$ & 2,342 & $\mathrm{~b}$ & 1,378 & $\mathrm{~b}$ \\
\hline N39 $\times$ Kansas Collier & 13,981 & $\mathrm{~b}$ & 14.9 & $a b$ & 2,068 & $\mathrm{~b}$ & 1,216 & $\mathrm{~b}$ \\
\hline N39 × Sugar Drip & 17,578 & $\mathrm{a}$ & 15.1 & $a b$ & 2,559 & & 1,505 & \\
\hline N39 $\times$ Waconia & 12,562 & $\mathrm{~b}$ & 15.1 & $a b$ & 1,866 & $\mathrm{~b}$ & 1,098 & $\mathrm{~b}$ \\
\hline N39 × Wray & 17,222 & $\mathrm{a}$ & 16.3 & $a b$ & 2,706 & & 1,592 & \\
\hline N4692 $\times$ Brawley & 15,618 & $\mathrm{ab}$ & 15.3 & $a b$ & 2,313 & $\mathrm{~b}$ & 1,361 & $\mathrm{~b}$ \\
\hline N4692 × Dale & 19,273 & $\mathrm{a}$ & 15 & $a b$ & 2,734 & & 1,608 & \\
\hline N4692 $\times$ Kansas Collier & 15,358 & $\mathrm{ab}$ & 15.2 & $\mathrm{ab}$ & 2,301 & $\mathrm{~b}$ & 1,354 & $\mathrm{~b}$ \\
\hline N4692 × Sugar Drip & 17,195 & $\mathrm{a}$ & 15.5 & $a b$ & 2,593 & & 1,525 & \\
\hline N4692 × Waconia & 14,914 & $\mathrm{~b}$ & 16.3 & $a b$ & 2,389 & $\mathrm{~b}$ & 1,405 & $\mathrm{~b}$ \\
\hline N4692 × Wray & 18,658 & $\mathrm{a}$ & 15.2 & $a b$ & 2,779 & & 1,634 & \\
\hline
\end{tabular}

Varietal results are shown in rows with italicized entries for convenience. Means in the same column followed by letter "a" are not significantly different from the highest value at $P=0.20$. Means in the same column followed by letter "b" are not significantly different from the lowest value at $P=0.20$ (see explanation in "Materials and Methods" for further details) 
Table 4 Fiber yield, calculated ethanol yields from fiber, and total calculated ethanol yields for six sweet sorghum varieties and 36 sweet sorghum hybrids

Varietal results are shown in rows with italicized entries for convenience. Means in the same column followed by letter "a" are not significantly different from the highest value at $P=$ 0.20 . Means in the same column followed by letter "b" are not significantly different from the lowest value at $P=0.20$ (see explanation in "Materials and Methods" for further details)

\begin{tabular}{|c|c|c|c|c|c|c|}
\hline \multirow{3}{*}{$\begin{array}{l}\text { Entry } \\
\text { Brawley }\end{array}$} & \multirow{2}{*}{\multicolumn{2}{|c|}{$\frac{\text { Fiber yield }}{\mathrm{kg} / \mathrm{ha}}$}} & \multirow{2}{*}{\multicolumn{2}{|c|}{$\begin{array}{l}\text { Ethanol from fiber } \\
\text { L/ha }\end{array}$}} & \multirow{2}{*}{\multicolumn{2}{|c|}{$\begin{array}{l}\text { Ethanol total } \\
\mathrm{L} / \mathrm{ha}\end{array}$}} \\
\hline & & & & & & \\
\hline & 15,466 & $b$ & 5,836 & $b$ & 9,057 & $b$ \\
\hline Dale & 18,987 & $a$ & 7,165 & $a$ & 9,291 & $b$ \\
\hline Kansas Collier & 17,717 & & 6,686 & & 9,842 & $a$ \\
\hline Sugar Drip & 24,101 & $a$ & 9,095 & $a$ & 12,394 & $a$ \\
\hline Waconia & 14,849 & $b$ & 5,603 & $b$ & 8,655 & $b$ \\
\hline Wray & 22,242 & $a$ & 8,393 & $a$ & 11,136 & $a$ \\
\hline Dwarf Kansas Sourless $\times$ Brawley & 17,371 & & 6,555 & & 10,094 & $\mathrm{a}$ \\
\hline Dwarf Kansas Sourless $\times$ Dale & 17,965 & & 6,779 & & 10,308 & $\mathrm{a}$ \\
\hline Dwarf Kansas Sourless $\times$ Kansas Collier & 14,513 & $\mathrm{~b}$ & 5,477 & $\mathrm{~b}$ & 9,075 & $\mathrm{~b}$ \\
\hline Dwarf Kansas Sourless $\times$ Sugar Drip & 17,004 & & 6,417 & & 9,721 & $\mathrm{~b}$ \\
\hline Dwarf Kansas Sourless $\times$ Waconia & 15,564 & $\mathrm{~b}$ & 5,873 & $\mathrm{~b}$ & 9,583 & $\mathrm{~b}$ \\
\hline Dwarf Kansas Sourless $\times$ Wray & 20,599 & a & 7,773 & a & 12,071 & a \\
\hline KS9 $\times$ Brawley & 14,686 & $\mathrm{~b}$ & 5,542 & $\mathrm{~b}$ & 9,075 & $\mathrm{~b}$ \\
\hline KS9 $\times$ Dale & 18,963 & a & 7,156 & a & 11,345 & a \\
\hline KS9 $\times$ Kansas Collier & 16,890 & & 6,374 & & 10,595 & a \\
\hline KS9 $\times$ Sugar Drip & 17,634 & & 6,654 & & 10,368 & $\mathrm{a}$ \\
\hline KS9 $\times$ Waconia & 11,726 & $\mathrm{~b}$ & 4,425 & $\mathrm{~b}$ & 7,232 & $\mathrm{~b}$ \\
\hline KS9 × Wray & 20,892 & $\mathrm{a}$ & 7,884 & a & 11,811 & $\mathrm{a}$ \\
\hline N36 × Brawley & 16,873 & & 6,367 & & 10,373 & a \\
\hline N36 × Dale & 17,520 & & 6,611 & & 10,468 & $\mathrm{a}$ \\
\hline N36 × Kansas Collier & 14,024 & $\mathrm{~b}$ & 5,292 & $\mathrm{~b}$ & 9,159 & $\mathrm{~b}$ \\
\hline N36 × Sugar Drip & 15,771 & $\mathrm{~b}$ & 5,951 & $\mathrm{~b}$ & 9,689 & $\mathrm{~b}$ \\
\hline N36 × Waconia & 12,658 & $\mathrm{~b}$ & 4,776 & $\mathrm{~b}$ & 8,142 & $\mathrm{~b}$ \\
\hline N36 × Wray & 18,237 & & 6,882 & & 11,156 & $\mathrm{a}$ \\
\hline $\mathrm{N} 38 \times$ Brawley & 14,094 & $\mathrm{~b}$ & 5,319 & $\mathrm{~b}$ & 9,119 & $\mathrm{~b}$ \\
\hline N38 $\times$ Dale & 15,148 & $\mathrm{~b}$ & 5,716 & $\mathrm{~b}$ & 9,398 & $\mathrm{~b}$ \\
\hline N38 $\times$ Kansas Collier & 12,420 & $\mathrm{~b}$ & 4,687 & $\mathrm{~b}$ & 8,117 & $\mathrm{~b}$ \\
\hline N38 × Sugar Drip & 13,135 & $\mathrm{~b}$ & 4,957 & $\mathrm{~b}$ & 8,618 & $\mathrm{~b}$ \\
\hline N38 $\times$ Waconia & 10,872 & $\mathrm{~b}$ & 4,103 & $\mathrm{~b}$ & 7,299 & $\mathrm{~b}$ \\
\hline N38 × Wray & 15,695 & $\mathrm{~b}$ & 5,923 & $\mathrm{~b}$ & 9,867 & $\mathrm{a}$ \\
\hline N39 × Brawley & 13,530 & $\mathrm{~b}$ & 5,106 & $\mathrm{~b}$ & 8,801 & $\mathrm{~b}$ \\
\hline N39 $\times$ Dale & 17,857 & & 6,738 & & 10,290 & $\mathrm{a}$ \\
\hline N39 × Kansas Collier & 14,195 & $\mathrm{~b}$ & 5,357 & $\mathrm{~b}$ & 9,005 & $\mathrm{~b}$ \\
\hline N39 × Sugar Drip & 18,326 & & 6,915 & & 10,481 & $\mathrm{a}$ \\
\hline N39 $\times$ Waconia & 12,683 & $\mathrm{~b}$ & 4,786 & $\mathrm{~b}$ & 8,179 & $\mathrm{~b}$ \\
\hline N39 × Wray & 17,604 & & 6,643 & & 11,004 & $\mathrm{a}$ \\
\hline N4692 $\times$ Brawley & 15,373 & $\mathrm{~b}$ & 5,801 & $\mathrm{~b}$ & 9,671 & $\mathrm{~b}$ \\
\hline N4692 $\times$ Dale & 19,758 & $\mathrm{a}$ & 7,456 & $\mathrm{a}$ & 11,506 & a \\
\hline N4692 $\times$ Kansas Collier & 14,724 & $\mathrm{~b}$ & 5,556 & $\mathrm{~b}$ & 9,583 & $b$ \\
\hline N4692 × Sugar Drip & 17,600 & & 6,642 & & 10,186 & $\mathrm{a}$ \\
\hline N4692 × Waconia & 13,638 & $\mathrm{~b}$ & 5,146 & $\mathrm{~b}$ & 8,778 & $\mathrm{~b}$ \\
\hline N4692 × Wray & 19,168 & $\mathrm{a}$ & 7,233 & $\mathrm{a}$ & 11,513 & $\mathrm{a}$ \\
\hline
\end{tabular}

may again be due to the differences in parental combinations over studies.

High-parent heterosis for juice yield was only observed in four hybrids (Dwarf Kansas Sourless $\times$ Brawley, KS9 $\times$
Dale, N39 $\times$ Dale, and N4692 $\times$ Dale), indicating that Dale would be a good male parent for this trait. However, only KS9 $\times$ Dale hybrid had heterosis for sugar yield and ethanol yield from sugar (Table 3 ). Hybrids tested by Audilakshmi 
Table 5 Correlation of values from three methods of estimating total $\%$ solids

\begin{tabular}{lccc}
\hline & Brix 5 plant & Brix 20 plant & $\%$ solids 20 plant \\
\cline { 2 - 4 } & $r$ & & \\
\hline Brix 5 plant & $1.00^{\mathrm{a}}$ & $0.67^{\mathrm{a}}$ & $0.67^{\mathrm{a}}$ \\
Brix 20 plant & $0.67^{\mathrm{a}}$ & $1.00^{\mathrm{a}}$ & $0.90^{\mathrm{a}}$ \\
\% solids 20 plant & $0.67^{\mathrm{a}}$ & $0.90^{\mathrm{a}}$ & $1.00^{\mathrm{a}}$ \\
\hline
\end{tabular}

${ }^{a}$ Significant at $P=0.05, n=250$

et al. [13] and Pfeiffer et al. [12] had considerable heterosis for juice and sugar yield. Heterosis for fiber yield and subsequently ethanol from it was observed in four of the 36 crosses (Dwarf Kansas Sourless $\times$ Brawley, Dwarf Kansas Sourless $\times$ Waconia, N36 $\times$ Brawley, and N4692 $\times$ Dale) (Table 4). However, it is interesting that 18 of the 36 crosses had heterosis for total ethanol yield (Table 4). This indicates the importance of grain yields for this particular set of crosses.

In terms of component (grain, juice, fiber) yields and overall ethanol yields, data suggest that one A-line is inferior. N38 hybrids had low juice, low \% soluble solids, and low fiber yields. Although grain yields of N38 hybrids were among the highest, total ethanol yields were lowest for N38 hybrids.

Average total ethanol yields from hybrids made on the other five A-lines (Dwarf Kansas Sourless, KS9, N36, N39, and N4692) were not significantly different, suggesting that any of these five A-lines could be useful seed-parents. Differences in average component yields would favor specific A-lines for production of hybrids for specific end-use applications. One drawback of our study was that it involved a single location over two field seasons. It will also be imperative to perform hybrid performance trials at other locations such as the Southeast to determine the best parents under very different environmental conditions. In the Southeast, plant heights would be expected to be higher and thus traits such as low lodging will be extremely important.

Fertility Restoration in the $F_{1}$ Hybrids

Although not a major objective of this research, the study did provide an opportunity to classify pollinator lines used for

\begin{tabular}{lllr}
$\begin{array}{l}\text { Table 6 Stepwise re- } \\
\text { gression results for } \\
\text { maximum } R^{2} \text { for total } \\
\text { ethanol }\end{array}$ & $\begin{array}{l}\text { Variable } \\
\text { added }\end{array}$ & $R^{2}$ & \multicolumn{2}{l}{$\begin{array}{l}\text { Mallow's } \\
\text { Cp }\end{array}$} \\
\cline { 2 - 3 } & Fiber yield & 0.9139 & 14,692 \\
& Grain yield & 0.9697 & 5,011 \\
& \% solids & 0.9859 & 2,205 \\
& Juice yield & 0.9986 & 9 \\
& Height & 0.9986 & 5 \\
& Days to heading & 0.9986 & 7 \\
\hline
\end{tabular}

fertility restoration reaction in the $\mathrm{A}_{1}$ cytoplasmic male sterile system. Dale and Wray hybrids appear to be good restorers (Rlines). Brawley, Kansas Collier, and Sugar Drip hybrids resulted in intermediate seed set under pollinating bags and would be classified as intermediate restorers. Waconia hybrids averaged $1.2 \%$ seed set under pollinating bags (possibly due to stigma exertion prior to bagging) and would be classified as a fertility maintainer (B-line). As such, Waconia offers the potential to make male sterile hybrids when crossed to sweet $\mathrm{A}_{1}$ cytoplasmic male sterile seed-parents. If grown in isolation from sorghum pollen sources, Waconia hybrids could be used to determine whether the absence of grain production would increase sugar levels in stems. Sorghum pollen was clearly present within the field plots; hence, the Waconia hybrids had grain yields that were not reduced compared to the other entries (Table 2).

Performance of Individual Hybrids and Sweet Sorghum Varieties

In the "Introduction," we indicated the need for sweet sorghum hybrids in order to produce the large amounts of seed required to support a developing bioenergy industry, which could be accomplished by commercial hybrid seed industries throughout the world. Hybrid sweet sorghums will, at a minimum, need to be equivalent in performance to existing sweet sorghum varieties to be acceptable to producers in addition to producing large quantities of seed for a sweet sorghum bioenergy industry to develop.

With the exception of grain yield, varietal sweet sorghums used as pollen parents were among the highest-performing entries for all traits (Tables 2, 3, and 4), including all traits directly contributing to total ethanol yield (grain yield, juice yield, \% soluble solids, sugar yield, fiber yield). No individual A-lines appeared to contribute disproportionately to hybrids among the top performers, indicating that identification of specific combinations of parental lines will be paramount in development of superior sweet sorghum hybrids. There was no clear indication of hybrid vigor among these crosses for sugar yield which was in contrast to other studies $[1,12,13]$. One study involved three of the same sweet sorghum pollen parents (Dale, Wray, Sun Drip), but the seed-parent lines for the $\mathrm{F} 1$ hybrid were all $\mathrm{A}_{3}$ cytoplasmic male sterile lines [12], in contrast to the $\mathrm{A}_{1}$ cytoplasmic male sterile lines used in this study. The other studies did not involve plant materials in common with this study $[1,13]$. For the other studies where hybrid vigor was observed, it was only present in a subset of the hybrid combination, underlining the fact that the individual combinations are paramount in hybrid performance.

Several details stand out: (1) Only one hybrid (Dwarf Kansas Sourless $\times$ Dale) was as tall as the tallest cultivar (Dale) (Table 2). Only the cultivar Wray (no hybrids) required as many days to reach $50 \%$ anthesis as did Dale. In many areas in which sweet sorghum can be grown, such 
long-season varieties present undesirable risk of frost damage and shorten harvest seasons. In our study, an early frost occurred prior to harvest in 1983 and there was a marked decrease $(\sim 15 \%)$ in the mean percent soluble solids and the mean sugar yields in 1983 compared to 1984 , but the mean juice volume was also decreased in 1983 relative to 1984; (2) For most traits (lodging, juice yield, \% soluble solids, fiber yield, and total ethanol yield), mean comparison tests did not parse the entries into distinct groups (Tables 2, 3, and 4). In fact, for the above traits, considerable overlap in grouping occurred with many intermediate entry means being statistically not different from both the lowest and highest entry means. In practice, experimental precision is low for these traits in the field and much higher numbers of replication will be required to discriminate effectively among entry means; (3) A subset of sweet sorghum varieties had the highest means, or was not significantly different from entries with highest means, for most traits contributing directly to total ethanol yields (juice yield, \% soluble solids, sugar yield, fiber yield) (Tables 3 and 4). Conversely, sweet sorghum varieties had lowest grain yields (Table 2). For sugar and fiber yields, sweet sorghum varieties establish the benchmark to be met by first-generation sweet sorghum hybrids; (4) Ethanol yields calculated from fiber were generally much higher than ethanol yields calculated from sugars in extracted juice or from grain (Tables 3 and 4). For example, calculated ethanol yields from grain, juice, and fiber of the cultivar Sugar Drip were 1,175, 2,124, and 9,095 L/ha, respectively.

Taken in aggregate, data from this study indicate that many hybrid combinations of dwarf sweet sorghum Alines and varietal sweet sorghum varieties used as pollinators can generate sweet $F_{1}$ hybrids with agronomic and yield parameters equivalent to sweet sorghum varieties. Selection of individual parental lines will of course be premised on end-use parameters. For example, the three hybrids Dwarf Kansas Sourless $\times$ Wray, N36 $\times$ Wray, and KS9 $\times$ Dale (Table 3) were equivalent in sugar yield from juice to the highest-yielding cultivar, Wray. Of this set of hybrids, they would be obvious choices for further evaluation for bioenergy systems utilizing only the juice from sweet sorghum. There was a much larger subset of hybrids with ethanol yield from fiber equivalent to the highest-yielding cultivar, Sugar Drip (Table 4). The hybrid KS9 $\times$ Wray ranked third to Sugar Drip in ethanol from fiber yield following Wray, but Dwarf Kansas Sourless $\times$ Wray, N4692 × Dale, N4692 $\times$ Wray, and KS9 $\times$ Dale were also not significantly different from Sugar Drip. Depending upon the relative importance of components (sugar in juice, fiber), in particular extraction and bioenergy production systems, optimal hybrid combinations could be selected.

Grain yields of hybrids were generally higher than for varieties (Table 2). Depending upon harvest systems, grain may or may not be advantageous. Current mechanized sugarcane harvesting systems "top", or cut and discard heads, as part of the harvest process. However, new mechanized systems may be developed to capture and utilize the sugars stored in the grain as starch, and this potential contributor to total potential ethanol production from sweet sorghum should not be ignored. This component would especially be important in areas that are currently converting corn or other starch crops into ethanol.

\section{Correlation of Estimates of \% Solids}

One of the challenges facing breeders developing sweet sorghum parental lines and downstream evaluators of sweet sorghum hybrids is how to measure sugar content. A common procedure because of its simplicity is to squeeze juice from a small number of sorghum stalks from an identified internode directly onto a hand-held refractometer. In this study, five plants were sampled and juice was squeezed from the fifth internode from the top of the plant. Values for percent solids generated in this manner were significantly, but not strongly correlated $(r=0.67)$, to values generated gravimetrically from juice of 20 whole plant samples (Table 3). Correlations between $\%$ solids estimated on the juice from the whole plant samples using a refractometer and gravimetric procedures were relatively high $(r=0.90)$. The simple conclusions to be drawn from these correlations are that, while use of a refractometer to estimate $\%$ solids from a sample correlates well to gravimetric measurement, the source of the sample itself is important and can contribute variation. In this experiment, juice extracted from the fifth internode of five plants did not adequately represent juice squeezed from total plants, and such procedures cannot be recommended for selection without further refinement. Similarly, in sugarcane, it has long been recognized that sample size has significant impact on estimating sugar content [31].

\section{Traits Contributing Most Strongly to Total Ethanol Yield}

Use of the MAXR Model in the PROC REG procedure of SAS/STAT software to determine the best models yielded the somewhat surprising result that a single factor model including only fiber yield accounted for $\sim 91 \%$ of the variation in total ethanol yields. Addition of grain yield, juice yield, and $\%$ solids to the model did improve the model and increase $R^{2}$ to nearly 1.00 , but from a practical point of view, these results suggest that improvement in the total ethanol yield potential may be accomplished by selection for fiber yield alone. Such an approach would not however take into account the relative importance of the individual components that may well outweigh total ethanol yield potential. For example, juice yield and sugar content of the juice will likely be of higher relative importance than fiber 
in systems such as existing sugarcane refineries because the fiber (bagasse) is typically considered a by-product used to generate heat and/or electricity through combustion.

General combining ability has been estimated to be relatively high for both free sugar and fiber components for sweet sorghum [32]. However, dominance effects and other nonadditive effects have also been reported as being important [13]. It will be important to make significant genetic gains from crossing and development of RIL lines to be used as female and pollen parents. High-sugar- and fiber-yielding RILs have been developed in this way in other programs $[10,11,30]$. Results of this study indicate that improvements can be made that will lead to useful sweet sorghum hybrids. Overall, there is significant sweet sorghum genetic diversity $[8,9]$, whose genetic potential was not captured in this study which included six sweet sorghum cultivars, three of which were in common with one previous study [9] and five were in common with another previous study [8].

\section{Conclusions}

Results of this study demonstrate that hybrid sweet sorghum with performance criteria equivalent to sweet sorghum varieties can be produced on the sweet sorghum seed-parent lines A-Dwarf Kansas Sourless, A-KS9, A-N36, A-N39, and AN4692. The average performance of A-N38 was generally lower in hybrid combination than the other seed-parent lines, but identification of specific seed-parent $\times$ pollen parent lines with characteristics best suited for particular growing regions and end-user needs will be critical for commercial hybrid development.

Acknowledgments The authors gratefully acknowledge that this study was conceived and conducted by Dr. Herman Gorz (USDA-ARS, retired), Dr. Francis Haskins (University of Nebraska-Lincoln, retired), and Dr. Max Clegg (University of Nebraska-Lincoln, retired). These individuals were offered co-authorship including the opportunity to read and evaluate the manuscript in a manner consistent with expectations outlined in the author guidelines of this journal, but declined. We thank John Toy (USDA-ARS), Carol Caha (University of Nebraska-Lincoln), and David Scoby (University of Nebraska-Lincoln) for their technical assistance with experimental data presented in this manuscript. The data presented in this publication are owned by the USDA-ARS and the integrity of the data is certified. The authors have the authority to disseminate these data.

\section{References}

1. Reddy BVS, Ramesh W, Reddy PS, Ramaiah B, Salimath PM, Kachapur R (2005) Sweet sorghum - a potential alternative raw material for bio-ethanol and bio-energy. J SAT Agric Res 1:1-8

2. Schaffert RE ( 2008) Development of cultivars for industrial processing/ethanol production in Brazil. Paper presented at the
International Workshop on Sorghum for Biofuels, Houston, TX. , August 19-22

3. Bellmer D, Huhnke R, Godsey C, Whiteley R, Holcomb R, Kenkel P, Gilliland S (2007) Use of sweet sorghum as a bioenergy crop for Oklahoma. USDA, Research, Education, and Economics Information System. http://www.reeis.usda.gov/web/crisprojectpages/ 210697.html. Accessed 4/21/2011

4. Davila-Gomez FJ, Chuck-Hernandez C, Perez-Carrillo E, Rooney WL, Serna-Saldivar SO (2011) Evaluation of bioethanol production from five different varieties of sweet and forage sorghums (Sorghum bicolor (L) Moench). Ind Crop Prod 33(3):611-616

5. Tew TL, Cobill RM, Richard EP (2008) Evaluation of sweet sorghum and sorghum $\times$ Sudangrass hybrids as feedstocks for ethanol production. BioEnergy Res 1(2):147-152

6. Rooney WL (2000) Genetics and cytogenetics. In: Smith CW, Frederiksen RA (eds) Sorghum: origin, history, technology, and production. Wiley, New York, pp 261-308

7. Ross WM, Gorz HJ, Haskins FA, Hookstra GH, Rutto JK, Ritter R (1983) Combining ability effects for forage residue traits in grainsorghum hybrids. Crop Sci 23(1):97-101

8. Murray SC, Rooney WL, Hamblin MT, Mitchell SE, Kresovich S (2009) Sweet sorghum genetic diversity and association mapping for brix and height. Plant Gen 2(1):48-62. doi:10.3835/ plantgenome2008.10.0011

9. Wang ML, Zhu C, Barkley NA, Chen Z, Erpelding JE, Murray SC et al (2009) Genetic diversity and population structure analysis of accessions in the US historic sweet sorghum collection. Theor Appl Genet 120(1):13-23

10. Ritter KB, Jordan DR, Chapman SC, Godwin ID, Mace ES, Lynne McIntyre C (2008) Identification of QTL for sugar-related traits in a sweet $\times$ grain sorghum (Sorghum bicolor L. Moench) recombinant inbred population. Mol Breed 22(3):367-384

11. Murray SC, Sharma A, Rooney WL, Klein PE, Mullet JE, Mitchell SE et al (2008) Genetic improvement of sorghum as a biofuel feedstock: I. QTL for stem sugar and grain nonstructural carbohydrates. Crop Sci 48(6):2165-2179

12. Pfeiffer TW, Bitzer MJ, Toy JJ, Pedersen JF (2010) Heterosis in sweet sorghum and selection of a new sweet sorghum hybrid for use in syrup production in Appalachia. Crop Sci 50(5):1788-1794. doi:10.2135/cropsci2009.09.0475

13. Audilakshmi S, Mall AK, Swarnalatha M, Seetharama N (2010) Inheritance of sugar concentration in stalk (brix), sucrose content, stalk and juice yield in sorghum. Biomass Bioenergy 34(6):813-820

14. Rooney WL, Smith CW (2000) Techniques for developing new cultivars. In: Smith CW, Frederiksen RA (eds) Sorghum: origin, history, technology, and production. Wiley, New York, pp 329-348

15. Fehrenbacher K (2008) 11 Companies racing to build U.S. cellulosic ethanol plants. Gigaom. http://gigaom.com/cleantech/12-companiesracing-to-build-cellulosic-ethanol-plants-in-the-us/. Accessed 8/12/ 2011

16. White House Office of Communications (2007) Twenty in ten: strengthening America's energy security. http://energy.gov/sites/ prod/files/edg/media/20in10FactSheet.pdf. Accessed 8/13/2011

17. Miller FR (1976) Release of A/BTx623. Report of Technical Committee on Seed Release and Increase. Texas Agri. Expt. Stn., College Station

18. Ross WM, Gorz HJ, Haskins FA, Webster OJ (1980) Registration of 10 sorghum parental lines. Crop Sci 20(6):834-834

19. Ross WM, Casady AJ, Lawless JR, Barnett FL (1972) 29 sorghum parental lines1 (Reg. Nos. PL1 and PL29). Crop Sci 12(5):722. doi:10.2135/cropsci1972.0011183X001200050086x

20. Webster OJ, Nordquist PT, Peters LV (1977) Registration of eight sorghum parental lines1 (Reg. No. PL 41 to PL 48). Crop Sci 17 (1):191. doi:10.2135/cropsci1977.0011183X001700010060x

21. Ross WM, Gorz HJ, Haskins FA, Kofoid KD (1979) Combining ability in forage sorghum hybrids. Maydica 24:83-93 
22. Kramer NW (1960) Registration of sorghum varieties, IX. Agron J 52(11):666. doi:10.2134/agronj1960.0002196200 5200110020x

23. Committee (1936) Registration of 73 sorghum varieties. J Am Agron Soc 28(12):1027-1028

24. Broadhead DM, Coleman OH (1973) Registration of Dale sweet sorghum. Crop Sci 13(6):776-776

25. Broadhead DM, Freeman KC, Zummo N (1981) Registration of Wray sweet sorghum. Crop Sci 21(6):987-987

26. Cooper J. How much ethanol can come from corn? National Corn Growers Association. http://www.cie.us/documents/ HowMuchEthanol.pdf. Accessed 4/27/2011

27. Energy UDo. Theoretical ethanol yield calculator. http://www.eere. energy.gov/biomass/ethanol_yield_calculator.html. Accessed 4/27/ 2011
28. Littell RC, Milliken GA, Stroup WW, Wolfinger RD, Schabenberger O (2006) SAS ${ }^{\circledR}$ for mixed models, 2nd edn. SAS Institute Inc., Cary

29. Annicchiarico P (2002) Estimation of individual effects and comparison of means. FAO Plant Production and Protection, Rome

30. Murray SC, Rooney WL, Mitchell SE, Sharma A, Klein PE, Mullet JE et al (2008) Genetic improvement of sorghum as a biofuel feedstock: II. QTL for stem and leaf structural carbohydrates. Crop Sci 48(6):2180-2193

31. Skinner JC (1976) Samples for measuring sugar content of sugar cane varieties in mechanically harvested trials. Int Sugar J 78 (932):227-230

32. Shiringani AL ( 2009) Identification of genomic regions of Sorghum bicolor (L.) Moench linked to biofuel-related traits in grain $\times$ sweet sorghum recombinant inbred lines. Justus-Liebig-University Giessen, Limpopo 
MONTHLY CLIMATOLOGICAL SUMMARY

1983
National Climatic Data Center Federal Building Asheville, North Carolina 28801

Station:GHCND:USC00255362, MEAD 6 S

Elev. $1154.86 \mathrm{~m}$. above sea level

Lat. $41.143^{\circ}$, Lon. $-96.481^{\circ}$

\begin{tabular}{|c|c|c|c|c|c|c|c|c|c|c|c|c|c|c|c|c|c|c|}
\hline Date & \multicolumn{11}{|c|}{ Temperature( $(\stackrel{\circ}{ } \mathrm{F})$} & \multicolumn{7}{|c|}{ Precipitation(in.) } \\
\hline Elem-> & MMXT & MMNT & MNTM & HTDD & CLDD & EMXT & EMNT & DT90 & DX32 & DT32 & DT00 & TPCP & EMXP & TSNW & MXSD & DP01 & DP05 & DP10 \\
\hline \multirow[b]{2}{*}{$\begin{array}{l}1983 \\
\text { Month }\end{array}$} & \multirow[b]{2}{*}{$\begin{array}{l}\text { Mean } \\
\text { Max. }\end{array}$} & \multirow[b]{2}{*}{ Mean Min. } & \multirow[b]{2}{*}{ Mean } & \multirow{2}{*}{$\begin{array}{c}\text { Heating } \\
\text { Degree } \\
\text { Days }\end{array}$} & \multirow{2}{*}{$\begin{array}{c}\text { Cooling } \\
\text { Degree } \\
\text { Days }\end{array}$} & \multirow[b]{2}{*}{ Highest } & \multirow[b]{2}{*}{ Lowest } & \multicolumn{4}{|c|}{ Number Of Days } & \multirow[b]{2}{*}{ Total } & \multirow[b]{2}{*}{$\begin{array}{c}\text { Greatest } \\
\text { Observed }\end{array}$} & \multicolumn{2}{|c|}{ Snow, Sleet } & \multicolumn{3}{|c|}{ Number Of Days } \\
\hline & & & & & & & & $\operatorname{Max}>=90^{\circ}$ & Max $<=32^{\circ}$ & $\operatorname{Min}<=32^{\circ}$ & $\operatorname{Min}<=0^{\circ}$ & & & Total Fall & $\begin{array}{c}\text { Max } \\
\text { Depth }\end{array}$ & $>=.10$ & $>=.50$ & $>=1.0$ \\
\hline 4 & 55.0 & 34.7 & 44.8 & 455.6 & 2.7 & 77.0 & 24.1 & 0 & 0 & 16 & 0 & 0.72 & 0.21 & 4.5 & 2.0 & 4 & 0 & 0 \\
\hline 5 & 72.9 & 43.7 & 58.3 & 120.2 & 68.8 & 93.0 & 32.0 & 2 & 0 & 2 & 0 & 4.87 & 2.44 & 0.0 & 0.0 & 7 & 2 & 1 \\
\hline 6 & 82.2 & 58.3 & 70.3 & 7.4 & 318.6 & 91.9 & 37.0 & 7 & 0 & 0 & 0 & 7.04 & 1.53 & 0.0 & 0.0 & 10 & 5 & 3 \\
\hline 7 & 92.7 & 64.8 & 78.8 & 13.5 & 596.7 & 102.9 & 39.9 & 23 & 0 & 0 & 0 & 0.78 & 0.29 & 0.0 & 0.0 & 4 & 0 & 0 \\
\hline 8 & 94.8 & 67.1 & 81.0 & 0.0 & 650.9 & 105.1 & 57.0 & 26 & 0 & 0 & 0 & 2.42 & 0.85 & 0.0 & 0.0 & 5 & 1 & 0 \\
\hline 9 & 84.4 & 51.4 & 67.6 & 47.7 & 272.9 & 99.0 & 27.0 & 12 & 0 & 2 & 0 & 2.83 & 1.37 & 0.0 & 0.0 & 3 & 2 & 1 \\
\hline 10 & 65.3 & 40.3 & 52.9 & 234.9 & 22.9 & 86.0 & 10.9 & 0 & 0 & 4 & 0 & 1.45 & 0.69 & 0.0 & 0.0 & 4 & 1 & 0 \\
\hline 11 & 51.1 & 27.9 & 39.4 & 574.6 & 2.2 & \begin{tabular}{l|l}
69.1 \\
\end{tabular} & 1.0 & 0 & 1 & 17 & 0 & 2.19 & 1.18 & 8.0 & 8.0 & 5 & 2 & 1 \\
\hline 12 & 21.2 & -1.7 & 9.9 & 851.6 & 0.0 & 36.0 & -27.0 & 0 & 15 & 17 & 8 & 0.05 & 0.03 & 4.0 & 11.0 & 0 & 0 & 0 \\
\hline Summary & 68.8 & 42.9 & 55.9 & 2305.5 & 1935.7 & 105.1 & -27.0 & 70 & 16 & 58 & 8 & 22.35 & 2.44 & 16.5 & 11.0 & 42 & 13 & 6 \\
\hline
\end{tabular}


Station:GHCND:USC00255362, MEAD 6 S

Elev. 1154.86m. above sea leve

Lat. $41.143^{\circ}$, Lon. $-96.481^{\circ}$

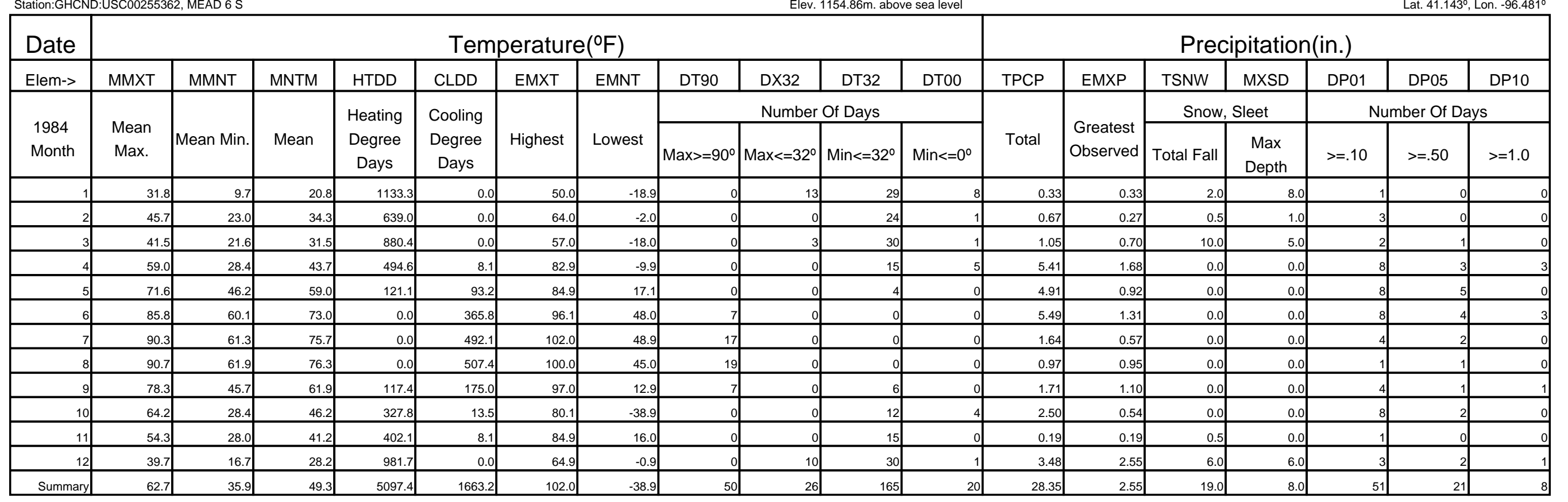


MONTHLY CLIMATOLOGICAL SUMMARY

1985
National Climatic Data Center Federal Building Asheville, North Carolina 28801

Station:GHCND:USC00255362, MEAD 6 S

Elev. 1154.86m. above sea level

Lat. $41.143^{\circ}$, Lon. $-96.481^{\circ}$

\begin{tabular}{|c|c|c|c|c|c|c|c|c|c|c|c|c|c|c|c|c|c|c|}
\hline \multirow{3}{*}{\begin{tabular}{l|} 
Date \\
Elem-> \\
\end{tabular}} & & & & & & & & & & $1154.80 \mathrm{~m} . \mathrm{abo}$ & e sealevel & & & & & & Lal. $41.140=$ & 0.0 .401$. \\
\hline & \multicolumn{11}{|c|}{ Temperature(요 $)$} & \multicolumn{7}{|c|}{ Precipitation(in.) } \\
\hline & MMXT & MMNT & MNTM & HTDD & CLDD & EMXT & EMNT & DT90 & DX32 & DT32 & DT00 & TPCP & EMXP & TSNW & MXSD & DP01 & DP05 & DP10 \\
\hline \multirow[b]{2}{*}{$\begin{array}{l}1985 \\
\text { Month }\end{array}$} & \multirow[b]{2}{*}{$\begin{array}{l}\text { Mean } \\
\text { Max. }\end{array}$} & \multirow[b]{2}{*}{ Mean Min. } & \multirow[b]{2}{*}{ Mean } & \multirow{2}{*}{$\begin{array}{c}\text { Heating } \\
\text { Degree } \\
\text { Days }\end{array}$} & \multirow{2}{*}{$\begin{array}{c}\text { Cooling } \\
\text { Degree } \\
\text { Days }\end{array}$} & \multirow[b]{2}{*}{ Highest } & \multirow[b]{2}{*}{ Lowest } & \multicolumn{4}{|c|}{ Number Of Days } & \multirow[b]{2}{*}{ Total } & \multirow{2}{*}{$\begin{array}{c}\text { Greatest } \\
\text { Observed }\end{array}$} & \multicolumn{2}{|c|}{ Snow, Sleet } & \multicolumn{3}{|c|}{ Number Of Days } \\
\hline & & & & & & & & $\operatorname{Max}>=90^{\circ}$ & Max $<=32^{\circ}$ & Min $<=32^{\circ}$ & $\operatorname{Min}<=0^{\circ}$ & & & Total Fall & $\begin{array}{c}\text { Max } \\
\text { Depth }\end{array}$ & $>=.10$ & $>=.50$ & $>=1.0$ \\
\hline & 31.1 & 8.2 & 19.6 & 1248.1 & 0.0 & 48.0 & -15.0 & 0 & 16 & 31 & 7 & 0.12 & 0.12 & 3.0 & 2.0 & & 0 & 0 \\
\hline 2 & 32.7 & 12.9 & 22.8 & 1038.2 & 0.0 & 55.0 & -15.0 & 0 & 14 & 26 & 9 & 0.49 & 0.46 & 0.0 & 1.0 & & 0 & 0 \\
\hline 3 & 55.4 & 30.9 & 43.2 & 520.0 & 1.6 & 75.0 & 17.1 & 0 & 1 & 22 & 0 & 0.37 & 0.20 & 0.5 & 0.0 & 2 & 0 & 0 \\
\hline 4 & 66.4 & 45.9 & 56.1 & 234.0 & 121.3 & 89.1 & 21.0 & 0 & 0 & 5 & 0 & 2.39 & 0.72 & 6.0 & 6.0 & 5 & 2 & 0 \\
\hline 5 & 9999 & 9999 & 9999 & 9999 & 9999 & 9999 & 9999 & 9999 & 9999 & 9999 & 9999 & 9999 & 9999 & 9999 & 9999 & 9999 & 9999 & 9999 \\
\hline 6 & 80.8 & 56.7 & 68.7 & 8.3 & 272.7 & 102.9 & 44.1 & 5 & 0 & 0 & 0 & 2.30 & 0.70 & 0.0 & 0.0 & 4 & 1 & 0 \\
\hline 7 & 87.4 & 62.1 & 74.8 & 0.0 & 461.5 & 98.1 & 53.1 & 12 & 0 & 0 & 0 & 3.65 & 2.81 & 0.0 & 0.0 & 4 & 2 & 1 \\
\hline 8 & 79.0 & 59.0 & 68.9 & 0.0 & 281.2 & 93.0 & 46.9 & 1 & 0 & 0 & 0 & 3.01 & 0.88 & 0.0 & 0.0 & 6 & 3 & 0 \\
\hline 9 & 74.3 & 54.7 & 64.4 & 102.1 & 234.0 & 99.0 & 32.0 & 4 & 0 & 2 & 0 & 2.63 & 0.73 & 0.0 & 0.0 & 6 & 2 & 0 \\
\hline 10 & 63.1 & 41.4 & 52.2 & 245.3 & 7.7 & 75.9 & 25.0 & 0 & 0 & 3 & 0 & 2.35 & 0.98 & 0.0 & 0.0 & 5 & 2 & 0 \\
\hline 11 & 38.7 & 20.3 & 29.5 & 911.7 & 0.0 & 66.9 & $\begin{array}{l}-5.1 \\
\end{array}$ & 0 & 12 & 26 & 2 & 0.86 & 0.73 & 3.0 & 3.0 & 1 & 1 & 0 \\
\hline 12 & 30.6 & 9.3 & 19.9 & 1240.6 & 0.0 & 46.0 & -15.0 & 0 & 12 & 29 & 10 & 0.19 & 0.07 & 4.0 & 4.0 & 0 & 0 & 0 \\
\hline Summary & 58.1 & 36.5 & 47.3 & 5548.3 & 1380.0 & 102.9 & -15.0 & 22 & 55 & 144 & 28 & 18.36 & 2.81 & 16.5 & 6.0 & 35 & 13 & 1 \\
\hline
\end{tabular}


MONTHLY CLIMATOLOGICAL SUMMARY

1986
National Climatic Data Center Federal Building Asheville, North Carolina 28801

Station:GHCND:USC00255362, MEAD 6 S

Elev. 1154.86m. above sea leve

Lat. $41.143^{\circ}$, Lon. $-96.481^{\circ}$

\begin{tabular}{|c|c|c|c|c|c|c|c|c|c|c|c|c|c|c|c|c|c|c|}
\hline \multirow{2}{*}{\multicolumn{12}{|c|}{ DIIOH. }} & & & & & & La. & 1. \\
\hline & & & & & & & & & & & & \multicolumn{7}{|c|}{ Precipitation(in.) } \\
\hline Elem-> & MMXT & MMNT & MNTM & HTDD & CLDD & EMXT & EMNT & DT90 & DX32 & DT32 & DT00 & TPCP & EMXP & TSNW & MXSD & DP01 & DP05 & DP10 \\
\hline \multirow[b]{2}{*}{$\begin{array}{l}1986 \\
\text { Month }\end{array}$} & \multirow[b]{2}{*}{$\begin{array}{l}\text { Mean } \\
\text { Max. }\end{array}$} & \multirow[b]{2}{*}{ Mean Min. } & \multirow[b]{2}{*}{ Mean } & \multirow{2}{*}{$\begin{array}{c}\text { Heating } \\
\text { Degree } \\
\text { Days }\end{array}$} & \multirow{2}{*}{$\begin{array}{c}\text { Cooling } \\
\text { Degree } \\
\text { Days }\end{array}$} & \multirow[b]{2}{*}{ Highest } & \multirow[b]{2}{*}{ Lowest } & \multicolumn{4}{|c|}{ Number Of Days } & \multirow[b]{2}{*}{ Total } & \multirow[b]{2}{*}{$\begin{array}{c}\text { Greatest } \\
\text { Observed }\end{array}$} & \multicolumn{2}{|c|}{ Snow, Sleet } & \multicolumn{3}{|c|}{ Number Of Days } \\
\hline & & & & & & & & Max $>=90^{\circ}$ & Max $<=32^{\circ}$ & Min $<=32^{\circ}$ & $\operatorname{Min}<=0^{\circ}$ & & & Total Fall & $\begin{array}{c}\text { Max } \\
\text { Depth }\end{array}$ & $>=.10$ & $>=.50$ & $>=1.0$ \\
\hline & 44.8 & 17.2 & 31.1 & 894.6 & 0.0 & 64.0 & -6.0 & 0 & 6 & 29 & 4 & 0.00 & 0.00 & 0.0 & 0.0 & 0 & 0 & 0 \\
\hline 2 & 34.3 & 12.7 & 23.5 & 1017.2 & 0.0 & 61.0 & -23.1 & 0 & 13 & 28 & 5 & 0.43 & 0.21 & 4.5 & 4.0 & & 0 & 0 \\
\hline 3 & 58.6 & 33.6 & 46.0 & 473.6 & 45.0 & 90.0 & 8.1 & 1 & 0 & 19 & 0 & 2.97 & 1.37 & 9999 & 9999 & 3 & 2 & 2 \\
\hline 4 & 64.8 & 40.1 & 52.5 & 254.3 & 31.0 & 84.9 & 23.0 & 0 & 1 & 8 & 0 & 5.30 & 2.38 & 0.5 & 0.0 & 7 & 4 & 2 \\
\hline 5 & 73.9 & 51.8 & 62.8 & 39.8 & 130.3 & 84.0 & 39.0 & 0 & 0 & 0 & 0 & 2.74 & 1.24 & 0.0 & 0.0 & 7 & 2 & 1 \\
\hline 6 & 86.9 & 62.2 & 74.7 & 0.0 & 440.3 & 96.1 & 51.1 & 14 & 0 & 0 & 0 & 3.19 & 1.50 & 0.0 & 0.0 & 6 & 2 & 1 \\
\hline 7 & 88.5 & 66.0 & 77.2 & 0.0 & 537.8 & 95.0 & 55.0 & 14 & 0 & 0 & 0 & 2.54 & 1.37 & 0.0 & 0.0 & 3 & 2 & 1 \\
\hline 8 & 78.6 & 58.5 & 68.5 & 7.0 & 275.6 & 88.0 & 39.9 & 0 & 0 & 0 & 0 & 5.60 & 1.38 & 0.0 & 0.0 & 8 & 6 & 2 \\
\hline 9 & 76.6 & 56.7 & 66.7 & 15.5 & 218.9 & 88.0 & 39.9 & 0 & 0 & 0 & 0 & 7.60 & 1.71 & 0.0 & 0.0 & 11 & 4 & 4 \\
\hline 10 & 64.4 & 42.3 & 53.2 & 215.5 & 10.1 & 84.0 & 26.1 & 0 & 0 & 3 & 0 & 4.65 & 2.81 & 0.0 & 0.0 & 5 & 2 & 1 \\
\hline 11 & 45.5 & 24.4 & 34.9 & 748.6 & 0.0 & 66.0 & -7.1 & 0 & 5 & 27 & 2 & 0.50 & 0.41 & 0.5 & 1.0 & 1 & 0 & 0 \\
\hline 12 & 38.1 & 23.7 & 30.9 & 897.8 & 0.0 & 59.0 & 1.0 & 0 & 5 & 29 & 0 & 0.73 & 0.50 & 5.0 & 3.0 & 2 & 1 & 0 \\
\hline Summary & 62.9 & 40.8 & 51.8 & 4563.9 & 1689.0 & 96.1 & -23.1 & 29 & 30 & 143 & 11 & 36.25 & 2.81 & 10.5 & 4.0 & 54 & 25 & 14 \\
\hline
\end{tabular}


MONTHLY CLIMATOLOGICAL SUMMARY

1987
National Climatic Data Center Federal Building Asheville, North Carolina 28801

Station:GHCND:USC00255362, MEAD 6 S

Elev. 1154.86m. above sea leve

Lat. $41.143^{\circ}$, Lon. $-96.481^{\circ}$

\begin{tabular}{|c|c|c|c|c|c|c|c|c|c|c|c|c|c|c|c|c|c|c|}
\hline \multirow{2}{*}{\multicolumn{12}{|c|}{ Temperature(으) }} & & & & & & La. & 1. \\
\hline & & & & & & & & & & & & \multicolumn{7}{|c|}{ Precipitation(in.) } \\
\hline Elem-> & MMXT & MMNT & MNTM & HTDD & CLDD & EMXT & EMNT & DT90 & DX32 & DT32 & DT00 & TPCP & EMXP & TSNW & MXSD & DP01 & DP05 & DP10 \\
\hline \multirow[b]{2}{*}{$\begin{array}{l}1987 \\
\text { Month }\end{array}$} & \multirow[b]{2}{*}{$\begin{array}{l}\text { Mean } \\
\text { Max. }\end{array}$} & \multirow[b]{2}{*}{ Mean Min. } & \multirow[b]{2}{*}{ Mean } & \multirow{2}{*}{$\begin{array}{c}\text { Heating } \\
\text { Degree } \\
\text { Days }\end{array}$} & \multirow{2}{*}{$\begin{array}{c}\text { Cooling } \\
\text { Degree } \\
\text { Days }\end{array}$} & \multirow[b]{2}{*}{ Highest } & \multirow[b]{2}{*}{ Lowest } & \multicolumn{4}{|c|}{ Number Of Days } & \multirow[b]{2}{*}{ Total } & \multirow[b]{2}{*}{$\begin{array}{c}\text { Greatest } \\
\text { Observed }\end{array}$} & \multicolumn{2}{|c|}{ Snow, Sleet } & \multicolumn{3}{|c|}{ Number Of Days } \\
\hline & & & & & & & & Max $>=90^{\circ}$ & Max $<=32^{\circ}$ & Min $<=32^{\circ}$ & $\operatorname{Min}<=0^{\circ}$ & & & Total Fall & $\begin{array}{c}\text { Max } \\
\text { Depth }\end{array}$ & $>=.10$ & $>=.50$ & $>=1.0$ \\
\hline & 41.2 & 18.3 & 29.7 & 935.1 & 0.0 & 66.0 & -2.0 & 0 & 7 & 30 & 1 & 0.00 & 0.00 & 0.0 & 0.0 & 0 & 0 & 0 \\
\hline 2 & 49.3 & 23.2 & 36.1 & 663.1 & 0.0 & 72.0 & 7.0 & 0 & 1 & 24 & 0 & 0.09 & 0.09 & 0.0 & 0.0 & 0 & 0 & 0 \\
\hline 3 & 51.8 & 30.9 & 41.4 & 572.9 & 0.0 & 77.0 & 7.0 & 0 & 2 & 16 & 0 & 4.13 & 1.53 & 5.0 & 5.0 & 8 & 3 & 1 \\
\hline 4 & 68.4 & 39.2 & 53.8 & 275.9 & 91.6 & 93.0 & 19.9 & 5 & 0 & 9 & 0 & 1.41 & 0.64 & 0.0 & 3.0 & 3 & 2 & 0 \\
\hline 5 & 78.4 & 55.6 & 66.9 & 32.4 & 252.0 & 93.0 & 43.0 & 4 & 0 & 0 & 0 & 6.22 & 2.90 & 0.0 & 0.0 & 8 & 3 & 2 \\
\hline 6 & 88.3 & 61.7 & 75.0 & 0.0 & 455.0 & 99.0 & 50.0 & 16 & 0 & 0 & 0 & 1.67 & 0.41 & 0.0 & 0.0 & 5 & 0 & 0 \\
\hline 7 & 89.2 & 65.8 & 77.5 & 0.0 & 545.6 & 98.1 & 51.1 & 18 & 0 & 0 & 0 & 3.84 & 2.02 & 0.0 & 0.0 & 5 & 3 & 1 \\
\hline 8 & 82.0 & 59.7 & 70.9 & 3.8 & 343.1 & 102.0 & 46.9 & 6 & 0 & 0 & 0 & 8.69 & 2.92 & 0.0 & 0.0 & 9 & 4 & 4 \\
\hline 9 & 77.0 & 51.3 & 64.0 & 21.2 & 147.6 & 89.1 & 41.0 & 0 & 0 & 0 & 0 & 1.86 & 0.62 & 0.0 & 0.0 & 3 & 3 & 0 \\
\hline 10 & 62.6 & 33.8 & 48.2 & 371.9 & 11.0 & 84.9 & 17.1 & 0 & 0 & 14 & 0 & 0.68 & 0.27 & 1.0 & 0.0 & 3 & 0 & 0 \\
\hline 11 & 54.0 & 32.7 & 43.3 & 501.1 & 4.7 & 73.9 & 15.1 & 0 & 1 & 19 & 0 & 1.23 & 0.45 & 5.5 & 3.0 & 4 & 0 & 0 \\
\hline 12 & 41.0 & 24.3 & 32.7 & 653.9 & 0.0 & 53.1 & 7.0 & 0 & 4 & 18 & 0 & 0.29 & 0.25 & 9999 & 9999 & 1 & 0 & 0 \\
\hline Summary & 65.3 & 41.4 & 53.3 & 4031.3 & 1850.6 & 102.0 & -2.0 & 49 & 15 & 130 & 1 & 30.11 & 2.92 & 11.5 & 5.0 & 49 & 18 & 8 \\
\hline
\end{tabular}


MONTHLY CLIMATOLOGICAL SUMMARY

1988
National Climatic Data Center Federal Building Asheville, North Carolina 28801

Station:GHCND:USC00255362, MEAD 6 S

Elev. 1154.86m. above sea level

Lat. $41.143^{\circ}$, Lon. $-96.481^{\circ}$

\begin{tabular}{|c|c|c|c|c|c|c|c|c|c|c|c|c|c|c|c|c|c|c|}
\hline \multirow{2}{*}{\multicolumn{12}{|c|}{ Temperature(으) }} & & & & & & Lat. & 1. \\
\hline & & & & & & & & & & & & \multicolumn{7}{|c|}{ Precipitation(in.) } \\
\hline Elem-> & MMXT & MMNT & MNTM & HTDD & CLDD & EMXT & EMNT & DT90 & DX32 & DT32 & DT00 & TPCP & EMXP & TSNW & MXSD & DP01 & DP05 & DP10 \\
\hline \multirow[b]{2}{*}{$\begin{array}{l}1988 \\
\text { Month }\end{array}$} & \multirow[b]{2}{*}{$\begin{array}{l}\text { Mean } \\
\text { Max. }\end{array}$} & \multirow[b]{2}{*}{ Mean Min. } & \multirow[b]{2}{*}{ Mean } & \multirow{2}{*}{$\begin{array}{c}\text { Heating } \\
\text { Degree } \\
\text { Days } \\
\end{array}$} & \multirow{2}{*}{$\begin{array}{c}\text { Cooling } \\
\text { Degree } \\
\text { Days }\end{array}$} & \multirow[b]{2}{*}{ Highest } & \multirow[b]{2}{*}{ Lowest } & \multicolumn{4}{|c|}{ Number Of Days } & \multirow[b]{2}{*}{ Total } & \multirow[b]{2}{*}{$\begin{array}{c}\text { Greatest } \\
\text { Observed }\end{array}$} & \multicolumn{2}{|c|}{ Snow, Sleet } & \multicolumn{3}{|c|}{ Number Of Days } \\
\hline & & & & & & & & Max $>=90^{\circ}$ & Max $<=32^{\circ}$ & Min $<=32^{\circ}$ & $\operatorname{Min}<=0^{\circ}$ & & & Total Fall & $\begin{array}{c}\text { Max } \\
\text { Depth }\end{array}$ & $>=.10$ & $>=.50$ & $>=1.0$ \\
\hline & 31.1 & 9.3 & 20.3 & 1227.8 & 0.0 & 57.0 & -9.0 & 0 & 14 & 31 & 12 & 0.46 & 0.46 & 2.5 & 2.0 & & 0 & 0 \\
\hline 2 & 35.1 & 8.6 & 21.9 & 1103.9 & 0.0 & 68.0 & -15.0 & 0 & 12 & 27 & 9 & 0.09 & 0.06 & 3.0 & 1.0 & 0 & 0 & 0 \\
\hline 3 & 57.4 & 28.4 & 42.8 & 534.6 & 7.2 & 81.0 & 10.0 & 0 & 1 & 21 & 0 & 0.05 & 0.05 & 0.5 & 1.0 & 0 & 0 & 0 \\
\hline 4 & 66.4 & 35.8 & 51.1 & 285.1 & 20.0 & 87.1 & 23.0 & 0 & 0 & 12 & 0 & 1.43 & 0.82 & 0.0 & 0.0 & 2 & 1 & 0 \\
\hline 5 & 81.1 & 55.2 & 68.2 & 10.8 & 200.9 & 91.9 & 41.0 & 3 & 0 & 0 & 0 & 1.36 & 0.54 & 0.0 & 0.0 & 3 & 1 & 0 \\
\hline 6 & 92.3 & 64.6 & 78.4 & 0.0 & 556.4 & 108.0 & 53.1 & 16 & 0 & 0 & 0 & 1.02 & 0.55 & 0.0 & 0.0 & 4 & 1 & 0 \\
\hline 7 & 87.8 & 63.1 & 75.4 & 0.9 & 451.3 & 102.0 & 52.0 & 14 & 0 & 0 & 0 & 3.35 & 1.62 & 0.0 & 0.0 & 4 & 3 & 2 \\
\hline 8 & 92.1 & 61.2 & 76.6 & 1.4 & 519.1 & 102.9 & 37.9 & 19 & 0 & 0 & 0 & 0.14 & 0.08 & 0.0 & 0.0 & 0 & 0 & 0 \\
\hline 9 & 82.2 & 54.5 & 68.4 & 24.8 & 279.7 & 102.0 & 37.0 & 11 & 0 & 0 & 0 & 4.80 & 1.99 & 0.0 & 0.0 & 6 & 3 & 2 \\
\hline 10 & 63.1 & 34.7 & 48.9 & 236.5 & 6.7 & 81.0 & 19.0 & 0 & 0 & 9 & 0 & 0.07 & 0.07 & 0.0 & 0.0 & 0 & 0 & 0 \\
\hline 11 & 51.6 & 28.9 & 40.3 & 566.6 & 0.0 & 64.0 & 10.9 & 0 & 0 & 17 & 0 & 1.60 & 0.69 & 3.0 & 3.0 & 3 & 2 & 0 \\
\hline 12 & 45.3 & 19.4 & 32.4 & 853.9 & 0.0 & 64.0 & 8.1 & 0 & 4 & 30 & 0 & 0.48 & 0.32 & 3.0 & 3.0 & 2 & 0 & 0 \\
\hline Summary & 65.5 & 38.6 & 52.1 & 4846.3 & 2041.3 & 108.0 & -15.0 & 63 & 31 & 147 & 21 & 14.85 & 1.99 & 12.0 & 3.0 & 25 & 11 & 4 \\
\hline
\end{tabular}


MONTHLY CLIMATOLOGICAL SUMMARY

1989
National Climatic Data Center Federal Building Asheville, North Carolina 28801

Station:GHCND:USC00255362, MEAD 6 S

Elev. 1154.86m. above sea level

Lat. $41.143^{\circ}$, Lon. $-96.481^{\circ}$

\begin{tabular}{|c|c|c|c|c|c|c|c|c|c|c|c|c|c|c|c|c|c|c|}
\hline \multirow{2}{*}{\multicolumn{12}{|c|}{ Temperature(으) }} & & & & & & Lat. & 1. \\
\hline & & & & & & & & & & & & \multicolumn{7}{|c|}{ Precipitation(in.) } \\
\hline Elem-> & MMXT & MMNT & MNTM & HTDD & CLDD & EMXT & EMNT & DT90 & DX32 & DT32 & DT00 & TPCP & EMXP & TSNW & MXSD & DP01 & DP05 & DP10 \\
\hline \multirow[b]{2}{*}{$\begin{array}{l}1989 \\
\text { Month }\end{array}$} & \multirow[b]{2}{*}{$\begin{array}{l}\text { Mean } \\
\text { Max. }\end{array}$} & \multirow[b]{2}{*}{ Mean Min. } & \multirow[b]{2}{*}{ Mean } & \multirow{2}{*}{$\begin{array}{c}\text { Heating } \\
\text { Degree } \\
\text { Days }\end{array}$} & \multirow{2}{*}{$\begin{array}{c}\text { Cooling } \\
\text { Degree } \\
\text { Days }\end{array}$} & \multirow[b]{2}{*}{ Highest } & \multirow[b]{2}{*}{ Lowest } & \multicolumn{4}{|c|}{ Number Of Days } & \multirow[b]{2}{*}{ Total } & \multirow[b]{2}{*}{$\begin{array}{c}\text { Greatest } \\
\text { Observed }\end{array}$} & \multicolumn{2}{|c|}{ Snow, Sleet } & \multicolumn{3}{|c|}{ Number Of Days } \\
\hline & & & & & & & & Max $>=90^{\circ}$ & Max $<=32^{\circ}$ & Min $<=32^{\circ}$ & $\operatorname{Min}<=0^{\circ}$ & & & Total Fall & $\begin{array}{c}\text { Max } \\
\text { Depth }\end{array}$ & $>=.10$ & $>=.50$ & $>=1.0$ \\
\hline & 44.8 & 19.6 & 32.2 & 860.9 & 0.0 & 64.0 & 3.0 & 0 & 2 & 29 & 0 & 0.80 & 0.53 & 0.5 & 1.0 & 2 & 1 & 0 \\
\hline 2 & 27.9 & 3.2 & 15.6 & 1242.2 & 0.0 & 66.0 & -20.0 & 0 & 17 & 28 & 13 & 0.02 & 0.02 & 11.7 & 6.0 & 0 & 0 & 0 \\
\hline 3 & 49.1 & 27.0 & 37.9 & 698.6 & 19.3 & 84.9 & 1.0 & 0 & 7 & 16 & 0 & 0.06 & 0.03 & 0.2 & 1.0 & 0 & 0 & 0 \\
\hline 4 & 69.8 & 40.1 & 55.0 & 261.5 & 118.4 & 97.0 & 17.1 & 5 & 0 & 9 & 0 & 0.99 & 0.72 & 0.0 & 0.0 & 3 & 1 & 0 \\
\hline 5 & 77.5 & 49.3 & 63.3 & 70.0 & 178.0 & 99.0 & 30.9 & 3 & 0 & 3 & 0 & 0.72 & 0.46 & 0.0 & 0.0 & 3 & 0 & 0 \\
\hline 6 & 81.7 & 56.7 & 69.3 & 8.3 & 287.8 & 99.0 & 41.0 & 3 & 0 & 0 & 0 & 4.14 & 1.88 & 0.0 & 0.0 & 5 & 4 & 1 \\
\hline 7 & 87.8 & 64.8 & 76.3 & 0.0 & 508.9 & 98.1 & 57.0 & 14 & 0 & 0 & 0 & 3.92 & 2.21 & 9999 & 0.0 & 3 & 3 & 2 \\
\hline 8 & 86.2 & 59.4 & 72.7 & 0.0 & 398.9 & 102.0 & 43.0 & 6 & 0 & 0 & 0 & 1.62 & 0.77 & 0.0 & 0.0 & 4 & 1 & 0 \\
\hline 9 & 74.8 & 49.3 & 62.1 & 85.0 & 144.2 & 93.9 & 32.0 & 1 & 0 & 3 & 0 & 3.08 & 1.85 & 0.0 & 0.0 & 5 & 1 & 1 \\
\hline 10 & 68.9 & 38.1 & 53.6 & 238.3 & 40.5 & 89.1 & 19.9 & 0 & 0 & 8 & 0 & 0.85 & 0.34 & 9999 & 0.0 & 3 & 0 & 0 \\
\hline 11 & 50.0 & 21.9 & 36.0 & 718.0 & 0.0 & 71.1 & 1.0 & 0 & 2 & 28 & 0 & 0.05 & 0.05 & 0.5 & 1.0 & 0 & 0 & 0 \\
\hline 12 & 28.6 & 5.7 & 17.1 & 1325.9 & 0.0 & 64.9 & -25.1 & 0 & 17 & 30 & 12 & 0.66 & 0.21 & 5.8 & 4.0 & 2 & 0 & 0 \\
\hline Summary & 62.3 & 36.3 & 49.3 & 5508.7 & 1696.0 & 102.0 & -25.1 & 32 & 45 & 154 & 25 & 16.91 & 2.21 & 18.7 & 6.0 & 30 & 11 & 4 \\
\hline
\end{tabular}


Station:GHCND:USC00255362, MEAD 6 S

Elev. 1154.86m. above sea leve

Lat. $41.143^{\circ}$, Lon. $-96.481^{\circ}$

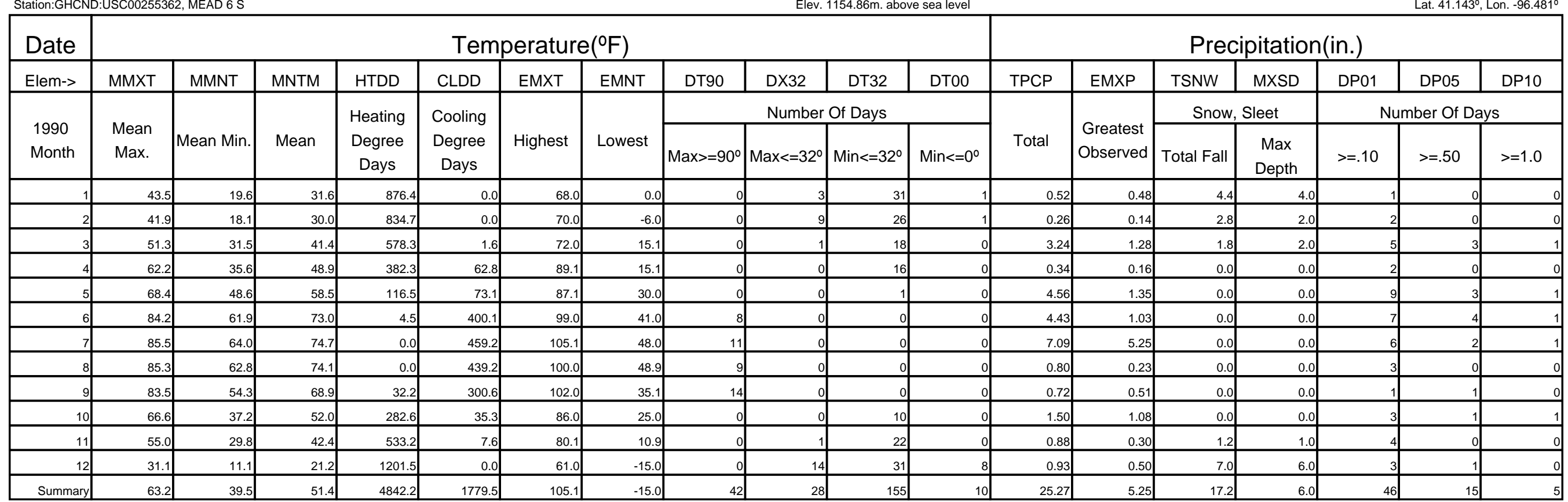


MONTHLY CLIMATOLOGICAL SUMMARY

1991
National Climatic Data Center Federal Building Asheville, North Carolina 28801

Station:GHCND:USC00255362, MEAD 6 S

Elev. 1154.86m. above sea level

Lat. $41.143^{\circ}$, Lon. $-96.481^{\circ}$

\begin{tabular}{|c|c|c|c|c|c|c|c|c|c|c|c|c|c|c|c|c|c|c|}
\hline \multirow{2}{*}{\multicolumn{12}{|c|}{ Temperature(으) }} & & & & & & La. & 1. \\
\hline & & & & & & & & & & & & \multicolumn{7}{|c|}{ Precipitation(in.) } \\
\hline Elem-> & MMXT & MMNT & MNTM & HTDD & CLDD & EMXT & EMNT & DT90 & DX32 & DT32 & DT00 & TPCP & EMXP & TSNW & MXSD & DP01 & DP05 & DP10 \\
\hline \multirow[b]{2}{*}{$\begin{array}{l}1991 \\
\text { Month }\end{array}$} & \multirow[b]{2}{*}{$\begin{array}{l}\text { Mean } \\
\text { Max. }\end{array}$} & \multirow[b]{2}{*}{ Mean Min. } & \multirow[b]{2}{*}{ Mean } & \multirow{2}{*}{$\begin{array}{c}\text { Heating } \\
\text { Degree } \\
\text { Days }\end{array}$} & \multirow{2}{*}{$\begin{array}{c}\text { Cooling } \\
\text { Degree } \\
\text { Days }\end{array}$} & \multirow[b]{2}{*}{ Highest } & \multirow[b]{2}{*}{ Lowest } & \multicolumn{4}{|c|}{ Number Of Days } & \multirow[b]{2}{*}{ Total } & \multirow[b]{2}{*}{$\begin{array}{c}\text { Greatest } \\
\text { Observed }\end{array}$} & \multicolumn{2}{|c|}{ Snow, Sleet } & \multicolumn{3}{|c|}{ Number Of Days } \\
\hline & & & & & & & & Max $>=90^{\circ}$ & Max $<=32^{\circ}$ & Min $<=32^{\circ}$ & $\operatorname{Min}<=0^{\circ}$ & & & Total Fall & $\begin{array}{c}\text { Max } \\
\text { Depth }\end{array}$ & $>=.10$ & $>=.50$ & $>=1.0$ \\
\hline & 24.6 & 1.9 & 13.3 & 1445.4 & 0.0 & 44.1 & -17.0 & 0 & 25 & 31 & 12 & 0.85 & 0.38 & 12.0 & 7.0 & 3 & 0 & 0 \\
\hline 2 & 44.2 & 22.5 & 33.4 & 742.0 & 0.0 & 66.0 & 5.0 & 0 & 2 & 27 & 0 & 0.28 & 0.28 & 0.1 & 4.0 & 1 & 0 & 0 \\
\hline 3 & 53.4 & 28.8 & 41.2 & 584.8 & 3.8 & 82.0 & 16.0 & 0 & 2 & 20 & 0 & 3.50 & 0.68 & 4.0 & 3.0 & 8 & 3 & 0 \\
\hline 4 & 65.7 & 42.6 & 54.1 & 218.7 & 44.3 & 87.1 & 32.0 & 0 & 0 & 2 & 0 & 2.65 & 0.78 & 0.0 & 0.0 & 5 & 3 & 0 \\
\hline 5 & 74.5 & 56.5 & 65.5 & 80.6 & 252.7 & 93.0 & 34.0 & 1 & 0 & 0 & 0 & 2.90 & 0.98 & 0.0 & 0.0 & 6 & 2 & 0 \\
\hline 6 & 84.4 & 64.4 & 74.5 & 0.0 & 421.0 & 97.0 & 54.0 & 7 & 0 & 0 & 0 & 9.94 & 3.20 & 0.0 & 0.0 & 7 & 6 & 4 \\
\hline 7 & 87.4 & 63.5 & 75.4 & 0.0 & 481.0 & 97.0 & 53.1 & 14 & 0 & 0 & 0 & 3.05 & 2.39 & 0.0 & 0.0 & 4 & 1 & 1 \\
\hline 8 & 85.5 & 61.2 & 73.2 & 0.0 & 387.2 & 96.1 & 52.0 & 9 & 0 & 0 & 0 & 1.80 & 0.78 & 0.0 & 0.0 & 4 & 1 & 0 \\
\hline 9 & 78.4 & 51.3 & 64.4 & 69.5 & 187.6 & 91.9 & 28.0 & 4 & 0 & 2 & 0 & 2.52 & 1.96 & 0.0 & 0.0 & 2 & 1 & 1 \\
\hline 10 & 66.0 & 36.1 & 51.1 & 302.8 & 29.3 & 84.0 & 17.1 & 0 & 0 & 12 & 0 & 0.28 & 0.14 & 0.0 & 0.0 & 2 & 0 & 0 \\
\hline 11 & 37.9 & 21.0 & 29.5 & 912.1 & 0.0 & 55.9 & -5.1 & 0 & 11 & 25 & 2 & 2.59 & 1.19 & 7.5 & 5.0 & 6 & 2 & 1 \\
\hline 12 & 39.9 & 23.7 & 31.8 & 870.5 & 0.0 & 55.9 & 7.0 & 0 & 5 & 27 & 0 & 2.01 & 0.92 & 0.0 & 0.0 & 4 & 2 & 0 \\
\hline Summary & 61.8 & 39.5 & 50.6 & 5226.4 & 1806.9 & 97.0 & -17.0 & 35 & 45 & 146 & 14 & 32.37 & 3.20 & 23.6 & 7.0 & 52 & 21 & 7 \\
\hline
\end{tabular}


MONTHLY CLIMATOLOGICAL SUMMARY

1992
National Climatic Data Center Federal Building Asheville, North Carolina 28801

Station:GHCND:USC00255362, MEAD 6 S

Elev. 1154.86m. above sea level

Lat. $41.143^{\circ}$, Lon. $-96.481^{\circ}$

\begin{tabular}{|c|c|c|c|c|c|c|c|c|c|c|c|c|c|c|c|c|c|c|}
\hline \multirow{2}{*}{$\begin{array}{l}\text { Date } \\
\text { Elem-> }\end{array}$} & \multicolumn{11}{|c|}{ Temperature(으) } & \multicolumn{7}{|c|}{ Precipitation(in.) } \\
\hline & MMXT & MMNT & MNTM & HTDD & CLDD & EMXT & EMNT & DT90 & DX32 & DT32 & DT00 & TPCP & EMXP & TSNW & MXSD & DP01 & DP05 & DP10 \\
\hline \multirow[b]{2}{*}{$\begin{array}{l}1992 \\
\text { Month }\end{array}$} & \multirow[b]{2}{*}{$\begin{array}{l}\text { Mean } \\
\text { Max. }\end{array}$} & \multirow[b]{2}{*}{ Mean Min. } & \multirow[b]{2}{*}{ Mean } & \multirow{2}{*}{$\begin{array}{c}\text { Heating } \\
\text { Degree } \\
\text { Days }\end{array}$} & \multirow{2}{*}{$\begin{array}{c}\text { Cooling } \\
\text { Degree } \\
\text { Days }\end{array}$} & \multirow[b]{2}{*}{ Highest } & \multirow[b]{2}{*}{ Lowest } & \multicolumn{4}{|c|}{ Number Of Days } & \multirow[b]{2}{*}{ Total } & \multirow[b]{2}{*}{$\begin{array}{c}\text { Greatest } \\
\text { Observed }\end{array}$} & \multicolumn{2}{|c|}{ Snow, Sleet } & \multicolumn{3}{|c|}{ Number Of Days } \\
\hline & & & & & & & & Max $>=90^{\circ}$ & Max $<=32^{\circ}$ & Min $<=32^{\circ}$ & $\operatorname{Min}<=0^{\circ}$ & & & Total Fall & $\begin{array}{c}\text { Max } \\
\text { Depth }\end{array}$ & $>=.10$ & $>=.50$ & $>=1.0$ \\
\hline & 43.9 & 24.3 & 34.0 & 801.7 & 0.0 & 60.1 & -0.9 & 0 & 2 & 25 & 2 & 0.71 & 0.29 & 0.0 & 0.0 & 3 & 0 & 0 \\
\hline 2 & 47.1 & 28.6 & 37.9 & 617.2 & 0.0 & 66.9 & 16.0 & 0 & 2 & 20 & 0 & 0.93 & 0.38 & 0.5 & 0.0 & 3 & 0 & 0 \\
\hline 3 & 58.6 & 35.6 & 47.1 & 399.1 & 3.2 & 81.0 & 19.9 & 0 & 0 & 11 & 0 & 2.57 & 0.83 & 0.0 & 0.0 & 5 & 1 & 0 \\
\hline 4 & 63.1 & 39.4 & 51.3 & 284.8 & 25.2 & 87.1 & 24.1 & 0 & 0 & 7 & 0 & 1.43 & 0.43 & 6.0 & 6.0 & 5 & 0 & 0 \\
\hline 5 & 75.4 & 49.6 & 62.4 & 69.8 & 146.0 & 91.9 & 32.0 & 1 & 0 & 1 & 0 & 1.69 & 0.43 & 0.0 & 0.0 & 6 & 0 & 0 \\
\hline 6 & 79.2 & 57.4 & 68.4 & 3.1 & 254.5 & 91.9 & 46.9 & 1 & 0 & 0 & 0 & 1.82 & 0.62 & 0.0 & 0.0 & 5 & 2 & 0 \\
\hline 7 & 80.1 & 59.9 & 70.0 & 0.0 & 314.5 & 89.1 & 52.0 & 0 & 0 & 0 & 0 & 7.18 & 1.80 & 0.0 & 0.0 & 11 & 6 & 2 \\
\hline 8 & 78.3 & 55.8 & 67.1 & 2.9 & 223.4 & 90.0 & 46.9 & 1 & 0 & 0 & 0 & 1.78 & 0.56 & 0.0 & 0.0 & 5 & 2 & 0 \\
\hline 9 & 76.5 & 50.2 & 63.3 & 48.1 & 150.5 & 88.0 & 34.0 & 0 & 0 & 0 & 0 & 2.24 & 0.81 & 0.0 & 0.0 & 5 & 2 & 0 \\
\hline 10 & 66.6 & 38.3 & 52.5 & 272.7 & 41.9 & 86.0 & 25.0 & 0 & 0 & 9 & 0 & 2.07 & 1.71 & 0.0 & 0.0 & 2 & 1 & 1 \\
\hline 11 & 40.8 & 27.0 & 33.8 & 781.6 & 0.0 & 64.0 & 10.0 & 0 & 5 & 24 & 0 & 2.06 & 0.82 & 3.9 & 3.0 & 4 & 2 & 0 \\
\hline 12 & 35.4 & 17.2 & 26.4 & 1040.2 & 0.0 & 46.9 & -0.9 & 0 & 14 & 29 & 1 & 0.51 & 0.31 & 3.3 & 3.0 & 2 & 0 & 0 \\
\hline Summary & 62.1 & 40.3 & 51.2 & 4321.2 & 1159.2 & 91.9 & -0.9 & 3 & 23 & 126 & 3 & 24.99 & 1.80 & 13.7 & 6.0 & 56 & 16 & 3 \\
\hline
\end{tabular}


MONTHLY CLIMATOLOGICAL SUMMARY

1993
National Climatic Data Center Federal Building Asheville, North Carolina 28801

Station:GHCND:USC00255362, MEAD 6 S

Elev. 1154.86m. above sea level

Lat. $41.143^{\circ}$, Lon. $-96.481^{\circ}$

\begin{tabular}{|c|c|c|c|c|c|c|c|c|c|c|c|c|c|c|c|c|c|c|}
\hline \multirow{2}{*}{\multicolumn{12}{|c|}{ Temperature(으) }} & & & & & & La. & 1. \\
\hline & & & & & & & & & & & & \multicolumn{7}{|c|}{ Precipitation(in.) } \\
\hline Elem-> & MMXT & MMNT & MNTM & HTDD & CLDD & EMXT & EMNT & DT90 & DX32 & DT32 & DT00 & TPCP & EMXP & TSNW & MXSD & DP01 & DP05 & DP10 \\
\hline \multirow[b]{2}{*}{$\begin{array}{l}1993 \\
\text { Month }\end{array}$} & \multirow[b]{2}{*}{$\begin{array}{l}\text { Mean } \\
\text { Max. }\end{array}$} & \multirow[b]{2}{*}{ Mean Min. } & \multirow[b]{2}{*}{ Mean } & \multirow{2}{*}{$\begin{array}{c}\text { Heating } \\
\text { Degree } \\
\text { Days }\end{array}$} & \multirow{2}{*}{$\begin{array}{c}\text { Cooling } \\
\text { Degree } \\
\text { Days }\end{array}$} & \multirow[b]{2}{*}{ Highest } & \multirow[b]{2}{*}{ Lowest } & \multicolumn{4}{|c|}{ Number Of Days } & \multirow[b]{2}{*}{ Total } & \multirow[b]{2}{*}{$\begin{array}{c}\text { Greatest } \\
\text { Observed }\end{array}$} & \multicolumn{2}{|c|}{ Snow, Sleet } & \multicolumn{3}{|c|}{ Number Of Days } \\
\hline & & & & & & & & Max $>=90^{\circ}$ & Max $<=32^{\circ}$ & Min $<=32^{\circ}$ & $\operatorname{Min}<=0^{\circ}$ & & & Total Fall & $\begin{array}{c}\text { Max } \\
\text { Depth }\end{array}$ & $>=.10$ & $>=.50$ & $>=1.0$ \\
\hline & 25.7 & 5.9 & 15.8 & 1366.4 & 0.0 & 48.0 & -8.0 & 0 & 22 & 31 & 8 & 0.85 & 0.33 & 11.3 & 8.0 & 3 & 0 & 0 \\
\hline 2 & 27.9 & 10.6 & 19.2 & 1140.1 & 0.0 & 45.0 & -9.9 & 0 & 17 & 28 & 9 & 0.56 & 0.20 & 3.0 & 4.0 & 2 & 0 & 0 \\
\hline 3 & 42.4 & 25.7 & 34.0 & 749.5 & 0.0 & 73.0 & 7.0 & 0 & 5 & 25 & 0 & 1.70 & 0.49 & 1.7 & 2.0 & 5 & 0 & 0 \\
\hline 4 & 57.2 & 35.6 & 46.4 & 406.3 & 0.0 & 73.9 & 21.0 & 0 & 0 & 7 & 0 & 3.42 & 0.80 & 0.0 & 0.0 & 9 & 1 & 0 \\
\hline 5 & 70.3 & 48.7 & 59.5 & 79.6 & 67.9 & 90.0 & 37.9 & 1 & 0 & 0 & 0 & 4.02 & 1.07 & 0.0 & 0.0 & 12 & 1 & 1 \\
\hline 6 & 79.5 & 57.0 & 68.2 & 17.1 & 267.3 & 93.9 & 45.0 & 2 & 0 & 0 & 0 & 7.94 & 2.44 & 0.0 & 0.0 & 11 & 5 & 2 \\
\hline 7 & 82.0 & 64.8 & 73.4 & 0.0 & 420.7 & 93.9 & 59.0 & 2 & 0 & 0 & 0 & 9.85 & 1.37 & 0.0 & 0.0 & 16 & 9 & 4 \\
\hline 8 & 83.3 & 64.6 & 73.9 & 0.4 & 435.2 & 93.9 & 50.0 & 6 & 0 & 0 & 0 & 7.14 & 2.55 & 0.0 & 0.0 & 8 & 3 & 3 \\
\hline 9 & 70.5 & 46.9 & 58.6 & 84.8 & 49.1 & 90.0 & 33.1 & 1 & 0 & 0 & 0 & 3.70 & 1.07 & 0.0 & 0.0 & 7 & 2 & 2 \\
\hline 10 & 61.9 & 38.8 & 50.4 & 327.2 & 32.6 & 84.9 & 14.0 & 0 & 1 & 10 & 0 & 1.34 & 0.61 & 0.0 & 0.0 & 3 & 1 & 0 \\
\hline 11 & 44.6 & 22.8 & 33.6 & 786.8 & 0.0 & 63.0 & 1.9 & 0 & 5 & 27 & 0 & 0.70 & 0.40 & 4.6 & 3.0 & 2 & 0 & 0 \\
\hline 12 & 38.7 & 20.3 & 29.5 & 942.1 & 0.0 & 64.0 & 3.9 & 0 & 8 & 30 & 0 & 0.21 & 0.13 & 3.3 & 3.0 & 1 & 0 & 0 \\
\hline Summary & 57.0 & 36.8 & 46.9 & 5900.3 & 1272.8 & 93.9 & -9.9 & 12 & 58 & 158 & 17 & 41.43 & 2.55 & 23.9 & 8.0 & 79 & 22 & 12 \\
\hline
\end{tabular}


MONTHLY CLIMATOLOGICAL SUMMARY

1994
National Climatic Data Center Federal Building Asheville, North Carolina 28801

Station:GHCND:USC00255362, MEAD 6 S

Elev. $1154.86 \mathrm{~m}$. above sea level

Lat. $41.143^{\circ}$, Lon. $-96.481^{\circ}$

\begin{tabular}{|c|c|c|c|c|c|c|c|c|c|c|c|c|c|c|c|c|c|c|}
\hline \multirow{2}{*}{$\begin{array}{l}\text { Date } \\
\text { Elem-> }\end{array}$} & \multicolumn{11}{|c|}{ Temperature(으) } & \multicolumn{7}{|c|}{ Precipitation(in.) } \\
\hline & MMXT & MMNT & MNTM & HTDD & CLDD & EMXT & EMNT & DT90 & $\mathrm{D} \times 32$ & DT32 & DT00 & TPCP & EMXP & TSNW & MXSD & DP01 & DP05 & DP10 \\
\hline \multirow{2}{*}{$\begin{array}{l}1994 \\
\text { Month }\end{array}$} & \multirow{2}{*}{$\begin{array}{l}\text { Mean } \\
\text { Max. }\end{array}$} & \multirow[b]{2}{*}{ Mean Min. } & \multirow[b]{2}{*}{ Mean } & \multirow{2}{*}{$\begin{array}{c}\text { Heating } \\
\text { Degree } \\
\text { Days }\end{array}$} & \multirow{2}{*}{$\begin{array}{c}\text { Cooling } \\
\text { Degree } \\
\text { Days }\end{array}$} & \multirow[b]{2}{*}{ Highest } & \multirow[b]{2}{*}{ Lowest } & \multicolumn{4}{|c|}{ Number Of Days } & \multirow[b]{2}{*}{ Total } & \multirow[b]{2}{*}{$\begin{array}{c}\text { Greatest } \\
\text { Observed }\end{array}$} & \multicolumn{2}{|c|}{ Snow, Sleet } & \multicolumn{3}{|c|}{ Number Of Days } \\
\hline & & & & & & & & Max $>=90^{\circ}$ & Max $<=32^{\circ}$ & $\operatorname{Min}<=32^{\circ}$ & Min $<=0^{\circ}$ & & & Total Fall & $\begin{array}{c}\text { Max } \\
\text { Depth }\end{array}$ & $>=.10$ & $>=.50$ & $>=1.0$ \\
\hline 1 & 29.5 & 9.7 & 19.6 & 1251.9 & 0.0 & 64.0 & -8.0 & 0 & 20 & 31 & 9 & 0.49 & 0.45 & 1.4 & 1.0 & 1 & 0 & 0 \\
\hline 2 & 30.6 & 9.0 & 19.8 & 1085.4 & 0.0 & 64.9 & -15.0 & 0 & 17 & 26 & 8 & 0.23 & 0.11 & 6.1 & 6.0 & 2 & 0 & 0 \\
\hline 3 & 54.7 & 26.1 & 40.5 & 606.6 & 1.3 & 78.1 & 12.9 & 0 & 1 & 25 & 0 & 0.01 & 0.01 & 0.0 & 2.0 & 0 & 0 & 0 \\
\hline 4 & 64.4 & 35.8 & 50.0 & 336.2 & 41.6 & 95.0 & 15.1 & 2 & 0 & 10 & 0 & 1.27 & 0.55 & 0.0 & 0.0 & 2 & 2 & 0 \\
\hline 5 & 75.7 & 49.1 & 62.4 & 97.2 & 174.6 & 96.1 & 28.0 & 2 & 0 & 2 & 0 & 1.43 & 0.43 & 0.0 & 0.0 & 6 & 0 & 0 \\
\hline 6 & 82.2 & 62.4 & 72.3 & 0.9 & 374.8 & 93.9 & 53.1 & 4 & 0 & 0 & 0 & 9.07 & 2.00 & 0.0 & 0.0 & 9 & 7 & 3 \\
\hline 7 & 82.6 & 59.5 & 71.1 & 0.0 & 346.5 & 91.9 & 51.1 & 1 & 0 & 0 & 0 & 4.23 & 1.66 & 0.0 & 0.0 & 8 & 3 & 1 \\
\hline 8 & 82.6 & 58.8 & 70.7 & 0.0 & 336.4 & 93.9 & 48.9 & 5 & 0 & 0 & 0 & 1.69 & 0.68 & 0.0 & 0.0 & 4 & 1 & 0 \\
\hline 9 & 78.1 & 51.8 & 64.9 & 53.5 & 203.8 & 93.0 & 37.0 & 2 & 0 & 0 & 0 & 3.73 & 1.92 & 0.0 & 0.0 & 4 & 3 & 1 \\
\hline 10 & 66.7 & 42.4 & 54.7 & 187.6 & 29.9 & 93.0 & 21.9 & 1 & 0 & 4 & 0 & 0.96 & 0.31 & 0.0 & 0.0 & 5 & 0 & 0 \\
\hline 11 & 50.4 & 30.2 & 40.3 & 568.8 & 0.0 & 71.1 & 21.0 & 0 & 0 & 18 & 0 & 2.42 & 1.18 & 1.0 & 1.0 & 3 & 2 & 1 \\
\hline 12 & 36.7 & 18.0 & 27.3 & 1007.6 & 0.0 & 57.0 & -8.0 & 0 & 12 & 31 & 2 & 0.64 & 0.42 & 8.6 & 5.0 & 2 & 0 & 0 \\
\hline Summary & 61.2 & 37.7 & 49.5 & 5195.7 & 1508.9 & 96.1 & -15.0 & 17 & 50 & 147 & 19 & 26.17 & 2.00 & 17.1 & 6.0 & 46 & 18 & 6 \\
\hline
\end{tabular}


MONTHLY CLIMATOLOGICAL SUMMARY

1995
National Climatic Data Center Federal Building Asheville, North Carolina 28801

Station:GHCND:USC00255362, MEAD 6 S

Elev. $1154.86 \mathrm{~m}$. above sea leve

Lat. $41.143^{\circ}$, Lon. $-96.481^{\circ}$

\begin{tabular}{|c|c|c|c|c|c|c|c|c|c|c|c|c|c|c|c|c|c|c|}
\hline Date & \multicolumn{11}{|c|}{ Temperature(으) } & \multicolumn{7}{|c|}{ Precipitation(in.) } \\
\hline Elem-> & MMXT & MMNT & MNTM & HTDD & CLDD & EMXT & EMNT & DT90 & DX32 & DT32 & DT00 & TPCP & EMXP & TSNW & MXSD & DP01 & DP05 & DP10 \\
\hline \multirow[b]{2}{*}{$\begin{array}{l}1995 \\
\text { Month }\end{array}$} & \multirow[b]{2}{*}{$\begin{array}{l}\text { Mean } \\
\text { Max. }\end{array}$} & \multirow[b]{2}{*}{ Mean Min. } & \multirow[b]{2}{*}{ Mean } & \multirow{2}{*}{$\begin{array}{c}\text { Heating } \\
\text { Degree } \\
\text { Days }\end{array}$} & \multirow{2}{*}{$\begin{array}{c}\text { Cooling } \\
\text { Degree } \\
\text { Days }\end{array}$} & \multirow[b]{2}{*}{ Highest } & \multirow[b]{2}{*}{ Lowest } & \multicolumn{4}{|c|}{ Number Of Days } & \multirow[b]{2}{*}{ Total } & \multirow[b]{2}{*}{$\begin{array}{c}\text { Greatest } \\
\text { Observed }\end{array}$} & \multicolumn{2}{|c|}{ Snow, Sleet } & \multicolumn{3}{|c|}{ Number Of Days } \\
\hline & & & & & & & & Max $>=90^{\circ}$ & Max $<=32^{\circ}$ & Min $<=32^{\circ}$ & $\operatorname{Min}<=0^{\circ}$ & & & Total Fall & $\begin{array}{c}\text { Max } \\
\text { Depth }\end{array}$ & $>=.10$ & $>=.50$ & $>=1.0$ \\
\hline & 30.4 & 11.5 & 21.0 & 1207.4 & 0.0 & 45.0 & -9.9 & 0 & 14 & 31 & 8 & 0.77 & 0.34 & 4.8 & 7.0 & 3 & 0 & 0 \\
\hline 2 & 43.0 & 19.6 & 31.3 & 800.8 & 0.0 & 77.0 & 1.9 & 0 & 10 & 27 & 0 & 0.41 & 0.28 & 1.6 & 1.0 & 1 & 0 & 0 \\
\hline 3 & 47.7 & 27.3 & 37.6 & 694.1 & 0.0 & 73.9 & -6.0 & 0 & 7 & 17 & 2 & 2.44 & 1.06 & 6.0 & 6.0 & 4 & 2 & 1 \\
\hline 4 & 57.7 & 34.7 & 46.2 & 385.6 & 1.1 & 80.1 & 21.9 & 0 & 0 & 14 & 0 & 4.30 & 0.87 & 0.0 & 0.0 & 9 & 3 & 0 \\
\hline 5 & 64.9 & 44.4 & 54.7 & 175.1 & 14.8 & 77.0 & 6.1 & 0 & 0 & 1 & 0 & 5.71 & 1.20 & 0.0 & 0.0 & 10 & 3 & 2 \\
\hline 6 & 80.6 & 59.4 & 70.0 & 11.9 & 315.5 & 93.0 & 48.0 & 6 & 0 & 0 & 0 & 1.31 & 0.29 & 0.0 & 0.0 & 7 & 0 & 0 \\
\hline 7 & 90.0 & 63.5 & 76.8 & 0.0 & 523.4 & 107.1 & 48.0 & 15 & 0 & 0 & 0 & 1.03 & 0.54 & 0.0 & 0.0 & 3 & 1 & 0 \\
\hline 8 & 89.6 & 66.4 & 77.9 & 0.0 & 560.3 & 99.0 & 55.9 & 16 & 0 & 0 & 0 & 1.34 & 0.57 & 0.0 & 0.0 & 3 & 1 & 0 \\
\hline 9 & 75.2 & 50.2 & 62.6 & 96.1 & 177.8 & 89.1 & 28.9 & 0 & 0 & 2 & 0 & 2.49 & 0.90 & 0.0 & 0.0 & 6 & 2 & 0 \\
\hline 10 & 65.5 & 39.9 & 52.7 & 248.9 & 26.5 & 89.1 & 26.1 & 0 & 0 & 3 & 0 & 1.36 & 0.50 & 0.0 & 0.0 & 3 & 1 & 0 \\
\hline 11 & 45.1 & 21.7 & 33.4 & 793.6 & 0.0 & 66.0 & 3.9 & 0 & 5 & 28 & 0 & 0.48 & 0.14 & 2.8 & 2.0 & 3 & 0 & 0 \\
\hline 12 & 36.5 & 19.9 & 28.2 & 984.6 & 0.0 & 69.1 & -2.0 & 0 & 15 & 28 & 2 & 0.35 & 0.14 & 3.9 & 2.0 & 1 & 0 & 0 \\
\hline Summary & 60.5 & 38.2 & 49.4 & 5398.1 & 1619.4 & 107.1 & -9.9 & 37 & 51 & 151 & 12 & 21.99 & 1.20 & 19.1 & 7.0 & 53 & 13 & 3 \\
\hline
\end{tabular}


MONTHLY CLIMATOLOGICAL SUMMARY

1996
National Climatic Data Center Federal Building Asheville, North Carolina 28801

Station:GHCND:USC00255362, MEAD 6 S

Elev. 1154.86m. above sea level

Lat. $41.143^{\circ}$, Lon. $-96.481^{\circ}$

\begin{tabular}{|c|c|c|c|c|c|c|c|c|c|c|c|c|c|c|c|c|c|c|}
\hline \multirow{2}{*}{$\begin{array}{l}\text { Date } \\
\text { Elem-> }\end{array}$} & \multicolumn{11}{|c|}{ Temperature $\left({ }^{\circ} \mathrm{F}\right)$} & \multicolumn{7}{|c|}{ Precipitation(in.) } \\
\hline & MMXT & MMNT & MNTM & HTDD & CLDD & EMXT & EMNT & DT90 & $\mathrm{DX} 32$ & DT32 & DT00 & TPCP & EMXP & TSNW & MXSD & DP01 & DP05 & DP10 \\
\hline \multirow{2}{*}{$\begin{array}{l}1996 \\
\text { Month }\end{array}$} & \multirow{2}{*}{$\begin{array}{l}\text { Mean } \\
\text { Max. }\end{array}$} & \multirow[b]{2}{*}{ Mean Min. } & \multirow[b]{2}{*}{ Mean } & \multirow{2}{*}{$\begin{array}{c}\text { Heating } \\
\text { Degree } \\
\text { Days }\end{array}$} & \multirow{2}{*}{$\begin{array}{c}\text { Cooling } \\
\text { Degree } \\
\text { Days }\end{array}$} & \multirow[b]{2}{*}{ Highest } & \multirow[b]{2}{*}{ Lowest } & \multicolumn{4}{|c|}{ Number Of Days } & \multirow[b]{2}{*}{ Total } & \multirow{2}{*}{$\begin{array}{l}\text { Greatest } \\
\text { Observed }\end{array}$} & \multicolumn{2}{|c|}{ Snow, Sleet } & \multicolumn{3}{|c|}{ Number Of Days } \\
\hline & & & & & & & & $\operatorname{Max}>=90^{\circ}$ & Max $<=32^{\circ}$ & $\operatorname{Min}<=32^{\circ}$ & $\operatorname{Min}<=0^{\circ}$ & & & Total Fall & $\begin{array}{c}\text { Max } \\
\text { Depth }\end{array}$ & $>=.10$ & $>=.50$ & $>=1.0$ \\
\hline 1 & 28.6 & 7.3 & 18.0 & 1300.7 & 0.0 & 68.0 & -18.9 & 0 & 19 & 31 & 11 & 0.50 & 0.19 & 9.1 & 5.0 & 2 & 0 & 0 \\
\hline 2 & 39.0 & 14.2 & 26.6 & 965.0 & 0.0 & 70.0 & -23.1 & 0 & 9 & 27 & 5 & 0.06 & 0.04 & 0.0 & 3.0 & 0 & 0 & 0 \\
\hline 3 & 44.6 & 17.4 & 30.9 & 897.5 & 0.0 & 72.0 & -5.1 & 0 & 6 & 28 & 3 & 0.90 & 0.65 & 3.2 & 3.0 & 2 & 1 & 0 \\
\hline 4 & 61.2 & 33.4 & 47.3 & 395.1 & 17.1 & 91.0 & 18.0 & 1 & 0 & 14 & 0 & 3.22 & 1.39 & 0.5 & 1.0 & 4 & 3 & 2 \\
\hline 5 & 66.0 & 49.3 & 57.7 & 150.5 & 81.0 & 91.9 & 33.1 & 1 & 0 & 0 & 0 & 7.30 & 1.68 & 0.0 & 0.0 & 16 & 6 & 2 \\
\hline 6 & 82.6 & 60.8 & 71.6 & 4.5 & 346.0 & 96.1 & 46.0 & 7 & 0 & 0 & 0 & 5.50 & 2.17 & 0.0 & 0.0 & 6 & 4 & 2 \\
\hline 7 & 82.9 & 61.0 & 72.0 & 0.0 & 375.1 & 97.0 & 50.0 & 3 & 0 & 0 & 0 & 1.46 & 0.42 & 0.0 & 0.0 & 4 & 0 & 0 \\
\hline 8 & 80.6 & 61.2 & 70.9 & 0.0 & 341.6 & 93.0 & 55.0 & 1 & 0 & 0 & 0 & 3.01 & 0.97 & 0.0 & 0.0 & 10 & 1 & 0 \\
\hline 9 & 72.9 & 50.4 & 61.5 & 69.7 & 118.4 & 87.1 & 37.9 & 0 & 0 & 0 & 0 & 1.99 & 0.95 & 0.0 & 0.0 & 3 & 2 & 0 \\
\hline 10 & 66.4 & 40.5 & 53.4 & 252.4 & 49.0 & 84.0 & 28.9 & 0 & 0 & 6 & 0 & 0.67 & 0.35 & 0.2 & 0.0 & 2 & 0 & 0 \\
\hline 11 & 39.6 & 23.2 & 31.3 & 857.5 & 0.0 & 64.0 & 7.0 & 0 & 10 & 27 & 0 & 2.32 & 1.24 & 1.5 & 1.0 & 4 & 2 & 1 \\
\hline 12 & 30.0 & 12.6 & 21.4 & 1196.3 & 0.0 & 46.9 & -4.0 & 0 & 13 & 31 & 6 & 0.38 & 0.12 & 3.1 & 1.0 & 2 & 0 & 0 \\
\hline Summary & 57.9 & 35.9 & 46.9 & 6089.2 & 1328.2 & 97.0 & -23.1 & 13 & 57 & 164 & 25 & 27.31 & 2.17 & 17.6 & 5.0 & 55 & 19 & 7 \\
\hline
\end{tabular}


MONTHLY CLIMATOLOGICAL SUMMARY

1997
National Climatic Data Center Federal Building Asheville, North Carolina 28801

Station:GHCND:USC00255362, MEAD 6 S

Elev. $1154.86 \mathrm{~m}$. above sea level

Lat. $41.143^{\circ}$, Lon. $-96.481^{\circ}$

\begin{tabular}{|c|c|c|c|c|c|c|c|c|c|c|c|c|c|c|c|c|c|c|}
\hline \multirow{2}{*}{\multicolumn{12}{|c|}{ Temperature(으) }} & & & & & & La. & 1. \\
\hline & & & & & & & & & & & & \multicolumn{7}{|c|}{ Precipitation(in.) } \\
\hline Elem-> & MMXT & MMNT & MNTM & HTDD & CLDD & EMXT & EMNT & DT90 & DX32 & DT32 & DT00 & TPCP & EMXP & TSNW & MXSD & DP01 & DP05 & DP10 \\
\hline \multirow[b]{2}{*}{$\begin{array}{l}1997 \\
\text { Month }\end{array}$} & \multirow[b]{2}{*}{$\begin{array}{l}\text { Mean } \\
\text { Max. }\end{array}$} & \multirow[b]{2}{*}{ Mean Min. } & \multirow[b]{2}{*}{ Mean } & \multirow{2}{*}{$\begin{array}{c}\text { Heating } \\
\text { Degree } \\
\text { Days }\end{array}$} & \multirow{2}{*}{$\begin{array}{c}\text { Cooling } \\
\text { Degree } \\
\text { Days }\end{array}$} & \multirow[b]{2}{*}{ Highest } & \multirow[b]{2}{*}{ Lowest } & \multicolumn{4}{|c|}{ Number Of Days } & \multirow[b]{2}{*}{ Total } & \multirow[b]{2}{*}{$\begin{array}{c}\text { Greatest } \\
\text { Observed }\end{array}$} & \multicolumn{2}{|c|}{ Snow, Sleet } & \multicolumn{3}{|c|}{ Number Of Days } \\
\hline & & & & & & & & Max $>=90^{\circ}$ & Max $<=32^{\circ}$ & Min $<=32^{\circ}$ & $\operatorname{Min}<=0^{\circ}$ & & & Total Fall & $\begin{array}{c}\text { Max } \\
\text { Depth }\end{array}$ & $>=.10$ & $>=.50$ & $>=1.0$ \\
\hline & 27.1 & 6.3 & 16.7 & 1336.9 & 0.0 & 55.0 & -14.1 & 0 & 20 & 31 & 13 & 0.24 & 0.10 & 4.1 & 3.0 & & 0 & 0 \\
\hline 2 & 36.9 & 19.2 & 28.0 & 891.2 & 0.0 & 63.0 & 1.9 & 0 & 12 & 27 & 0 & 0.94 & 0.62 & 7.0 & 4.0 & 2 & 1 & 0 \\
\hline 3 & 52.9 & 26.6 & 39.7 & 606.6 & 0.7 & 77.0 & 12.0 & 0 & 1 & 24 & 0 & 0.72 & 0.38 & 0.0 & 0.0 & 3 & 0 & 0 \\
\hline 4 & 55.8 & 33.6 & 44.6 & 459.5 & 1.8 & 82.0 & 19.9 & 0 & 4 & 13 & 0 & 2.45 & 0.56 & 4.8 & 4.0 & 9 & 1 & 0 \\
\hline 5 & 68.9 & 43.3 & 56.1 & 167.8 & 50.9 & 91.0 & 28.0 & 1 & 0 & 4 & 0 & 1.11 & 0.36 & 0.0 & 0.0 & 3 & 0 & 0 \\
\hline 6 & 85.1 & 59.7 & 72.5 & 0.0 & 376.2 & 98.1 & 48.9 & 7 & 0 & 0 & 0 & 2.53 & 0.82 & 0.0 & 0.0 & 5 & 2 & 0 \\
\hline 7 & 87.1 & 63.9 & 75.4 & 0.0 & 482.2 & 100.0 & 51.1 & 13 & 0 & 0 & 0 & 3.03 & 0.95 & 0.0 & 0.0 & 7 & 3 & 0 \\
\hline 8 & 82.6 & 60.4 & 71.6 & 2.0 & 362.2 & 95.0 & 53.1 & 6 & 0 & 0 & 0 & 2.03 & 0.85 & 0.0 & 0.0 & 5 & 2 & 0 \\
\hline 9 & 79.0 & 53.8 & 66.4 & 14.4 & 209.7 & 91.9 & 42.1 & 2 & 0 & 0 & 0 & 4.24 & 2.02 & 0.0 & 0.0 & 4 & 2 & 2 \\
\hline 10 & 65.5 & 39.7 & 52.7 & 322.9 & 97.9 & 91.0 & 9.0 & 3 & 2 & 7 & 0 & 3.46 & 1.73 & 8.0 & 8.0 & 5 & 3 & 1 \\
\hline 11 & 45.5 & 25.0 & 35.2 & 739.3 & 0.0 & 63.0 & 8.1 & 0 & 2 & 23 & 0 & 2.44 & 2.38 & 0.3 & 0.0 & 1 & 1 & 1 \\
\hline 12 & 35.8 & 22.6 & 29.1 & 951.5 & 0.0 & 50.0 & 12.9 & 0 & 14 & 31 & 0 & 0.42 & 0.22 & 2.8 & 2.0 & 1 & 0 & 0 \\
\hline Summary & 60.2 & 37.8 & 49.0 & 5492.1 & 1581.6 & 100.0 & -14.1 & 32 & 55 & 160 & 13 & 23.61 & 2.38 & 27.0 & 8.0 & 46 & 15 & 4 \\
\hline
\end{tabular}


MONTHLY CLIMATOLOGICAL SUMMARY

1998
National Climatic Data Center Federal Building Asheville, North Carolina 28801

Station:GHCND:USC00255362, MEAD 6 S

Elev. 1154.86m. above sea level

Lat. $41.143^{\circ}$, Lon. $-96.481^{\circ}$

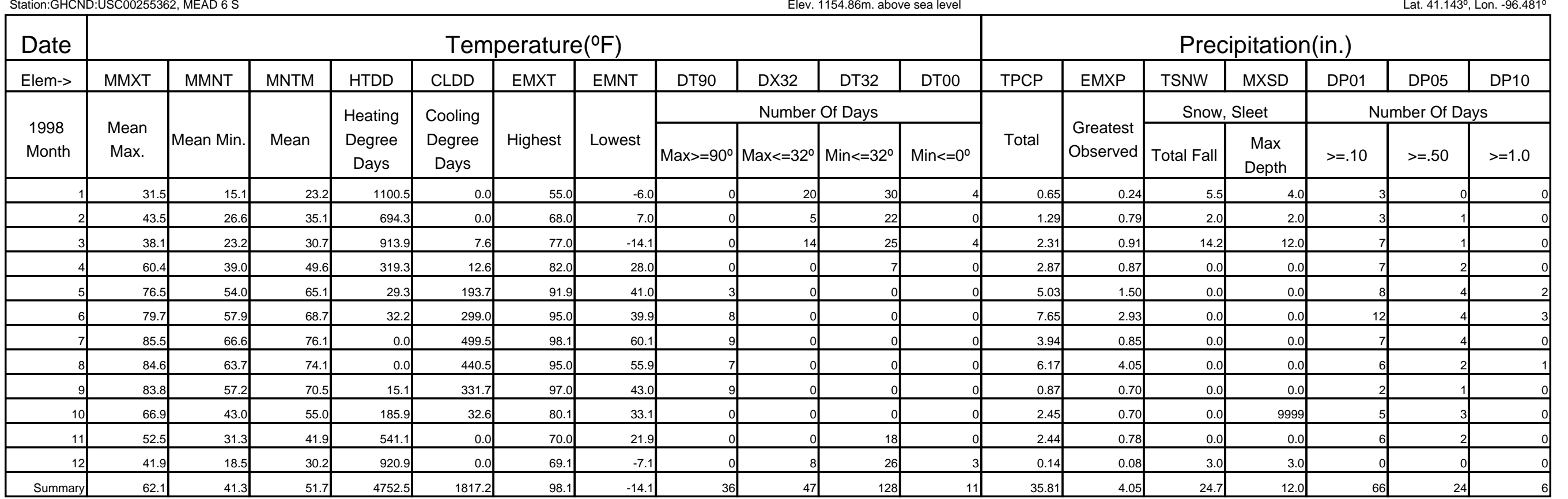


MONTHLY CLIMATOLOGICAL SUMMARY

1999
National Climatic Data Center Federal Building Asheville, North Carolina 28801

Station:GHCND:USC00255362, MEAD 6 S

Elev. 1154.86m. above sea level

Lat. $41.143^{\circ}$, Lon. $-96.481^{\circ}$

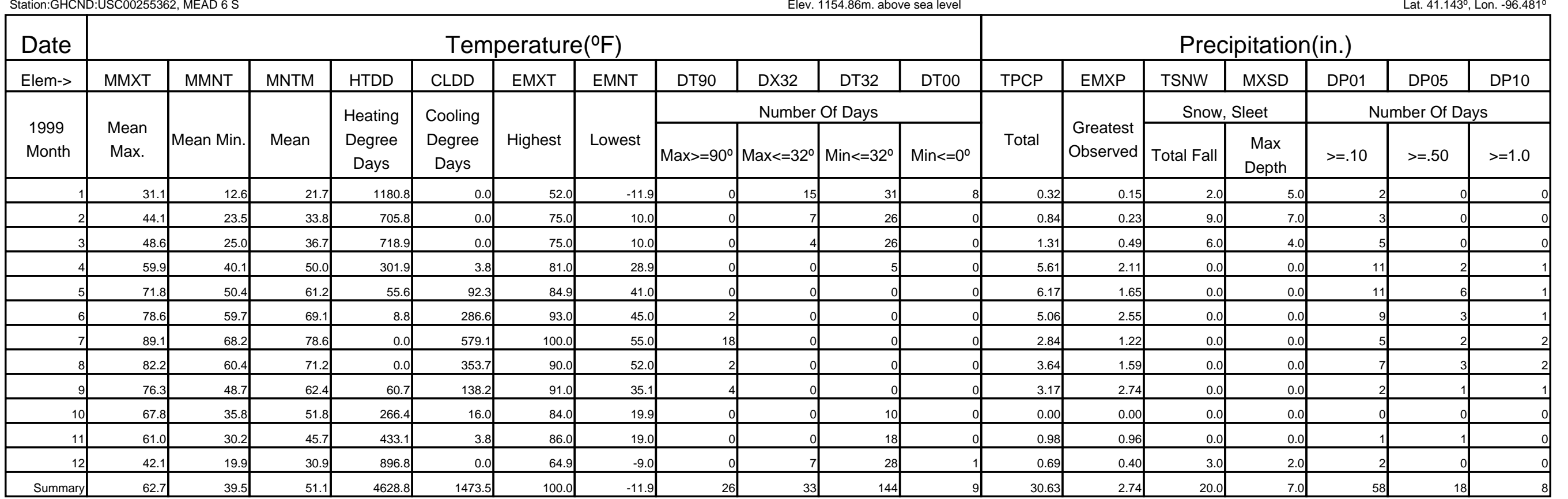


MONTHLY CLIMATOLOGICAL SUMMARY

2000
National Climatic Data Center Federal Building Asheville, North Carolina 28801

Station:GHCND:USC00255362, MEAD 6 S

Elev. 1154.86m. above sea level

Lat. $41.143^{\circ}$, Lon. $-96.481^{\circ}$

\begin{tabular}{|c|c|c|c|c|c|c|c|c|c|c|c|c|c|c|c|c|c|c|}
\hline \multirow{2}{*}{\multicolumn{12}{|c|}{ Temperature(으) }} & & & & & & La. & 1. \\
\hline & & & & & & & & & & & & \multicolumn{7}{|c|}{ Precipitation(in.) } \\
\hline Elem-> & MMXT & MMNT & MNTM & HTDD & CLDD & EMXT & EMNT & DT90 & DX32 & DT32 & DT00 & TPCP & EMXP & TSNW & MXSD & DP01 & DP05 & DP10 \\
\hline \multirow[b]{2}{*}{$\begin{array}{l}2000 \\
\text { Month }\end{array}$} & \multirow[b]{2}{*}{$\begin{array}{l}\text { Mean } \\
\text { Max. }\end{array}$} & \multirow[b]{2}{*}{ Mean Min. } & \multirow[b]{2}{*}{ Mean } & \multirow{2}{*}{$\begin{array}{c}\text { Heating } \\
\text { Degree } \\
\text { Days }\end{array}$} & \multirow{2}{*}{$\begin{array}{c}\text { Cooling } \\
\text { Degree } \\
\text { Days }\end{array}$} & \multirow[b]{2}{*}{ Highest } & \multirow[b]{2}{*}{ Lowest } & \multicolumn{4}{|c|}{ Number Of Days } & \multirow[b]{2}{*}{ Total } & \multirow[b]{2}{*}{$\begin{array}{c}\text { Greatest } \\
\text { Observed }\end{array}$} & \multicolumn{2}{|c|}{ Snow, Sleet } & \multicolumn{3}{|c|}{ Number Of Days } \\
\hline & & & & & & & & Max $>=90^{\circ}$ & Max $<=32^{\circ}$ & Min $<=32^{\circ}$ & $\operatorname{Min}<=0^{\circ}$ & & & Total Fall & $\begin{array}{c}\text { Max } \\
\text { Depth }\end{array}$ & $>=.10$ & $>=.50$ & $>=1.0$ \\
\hline & 38.3 & 15.8 & 27.1 & 1017.9 & 0.0 & 57.0 & 3.0 & 0 & 10 & 31 & 0 & 0.07 & 0.07 & 0.5 & 1.0 & 0 & 0 & 0 \\
\hline 2 & 46.9 & 20.8 & 34.0 & 754.2 & 0.0 & 70.0 & 8.1 & 0 & 5 & 23 & 0 & 0.80 & 0.29 & 5.3 & 5.0 & 3 & 0 & 0 \\
\hline 3 & 55.0 & 31.3 & 43.2 & 519.1 & 2.2 & 73.9 & 15.1 & 0 & 0 & 17 & 0 & 1.60 & 0.75 & 0.0 & 0.0 & 4 & 1 & 0 \\
\hline 4 & 63.7 & 36.1 & 50.0 & 305.8 & 6.1 & 87.1 & 21.9 & 0 & 0 & 7 & 0 & 2.28 & 0.76 & 0.0 & 0.0 & 5 & 3 & 0 \\
\hline 5 & 77.7 & 51.8 & 64.8 & 39.1 & 184.7 & 96.1 & 39.0 & 4 & 0 & 0 & 0 & 2.29 & 0.62 & 0.0 & 0.0 & 7 & 2 & 0 \\
\hline 6 & 83.1 & 57.7 & 70.5 & 2.3 & 320.2 & 97.0 & 45.0 & 6 & 0 & 0 & 0 & 5.63 & 2.08 & 0.0 & 0.0 & 6 & 5 & 2 \\
\hline 7 & 83.7 & 64.6 & 74.1 & 0.0 & 442.1 & 93.0 & 55.9 & 7 & 0 & 0 & 0 & 3.83 & 1.07 & 0.0 & 0.0 & 9 & 3 & 1 \\
\hline 8 & 87.6 & 65.8 & 76.6 & 0.0 & 520.9 & 100.9 & 57.0 & 11 & 0 & 0 & 0 & 1.17 & 0.70 & 0.0 & 0.0 & 3 & 1 & 0 \\
\hline 9 & 82.2 & 50.5 & 66.4 & 61.7 & 256.0 & 107.1 & 35.1 & 9 & 0 & 0 & 0 & 0.80 & 0.30 & 0.0 & 0.0 & 3 & 0 & 0 \\
\hline 10 & 69.3 & 42.3 & 55.8 & 181.6 & 52.9 & 91.9 & 19.0 & 1 & 0 & 6 & 0 & 2.13 & 1.16 & 0.0 & 0.0 & 6 & 1 & 1 \\
\hline 11 & 42.6 & 21.9 & 32.4 & 834.8 & 6.7 & 75.9 & 8.1 & 0 & 7 & 26 & 0 & 1.78 & 1.23 & 2.0 & 1.0 & 4 & 1 & 1 \\
\hline 12 & 23.0 & 4.3 & 13.6 & 1432.3 & 0.0 & 57.0 & -14.1 & 0 & 23 & 31 & 15 & 0.75 & 0.24 & 8.0 & 11.0 & 3 & 0 & 0 \\
\hline Summary & 62.8 & 38.6 & 50.7 & 5148.8 & 1791.8 & 107.1 & -14.1 & 38 & 45 & 141 & 15 & 23.13 & 2.08 & 15.8 & 11.0 & 53 & 17 & 5 \\
\hline
\end{tabular}


MONTHLY CLIMATOLOGICAL SUMMARY

2001
National Climatic Data Center Federal Building Asheville, North Carolina 28801

Station:GHCND:USC00255362, MEAD 6 S

Elev. 1154.86m. above sea leve

Lat. $41.143^{\circ}$, Lon. $-96.481^{\circ}$

\begin{tabular}{|c|c|c|c|c|c|c|c|c|c|c|c|c|c|c|c|c|c|c|}
\hline \multicolumn{19}{|c|}{ 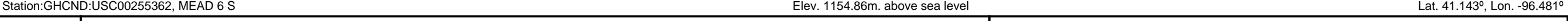 } \\
\hline Date & \multicolumn{11}{|c|}{ Temperature( $\left.{ }^{\circ} \mathrm{F}\right)$} & \multicolumn{7}{|c|}{ Precipitation(in.) } \\
\hline Elem-> & MMXT & MMNT & MNTM & HTDD & CLDD & EMXT & EMNT & DT90 & DX32 & DT32 & DT00 & TPCP & EMXP & TSNW & MXSD & DP01 & DP05 & DP10 \\
\hline \multirow{2}{*}{$\begin{array}{l}2001 \\
\text { Month }\end{array}$} & \multirow{2}{*}{$\begin{array}{l}\text { Mean } \\
\text { Max. }\end{array}$} & \multirow[b]{2}{*}{ Mean Min. } & \multirow[b]{2}{*}{ Mean } & \multirow{2}{*}{$\begin{array}{c}\text { Heating } \\
\text { Degree } \\
\text { Days }\end{array}$} & \multirow{2}{*}{$\begin{array}{c}\text { Cooling } \\
\text { Degree } \\
\text { Days }\end{array}$} & \multirow[b]{2}{*}{ Highest } & \multirow[b]{2}{*}{ Lowest } & \multicolumn{4}{|c|}{ Number Of Days } & \multirow[b]{2}{*}{ Total } & \multirow[b]{2}{*}{$\begin{array}{c}\text { Greatest } \\
\text { Observed }\end{array}$} & \multicolumn{2}{|c|}{ Snow, Sleet } & \multicolumn{3}{|c|}{ Number Of Days } \\
\hline & & & & & & & & Max $>=90^{\circ}$ & Max $<=32^{\circ}$ & Min $<=32^{\circ}$ & $\operatorname{Min}<=0^{\circ}$ & & & Total Fall & $\begin{array}{l}\text { Max } \\
\text { Depth }\end{array}$ & $>=.10$ & $>=.50$ & $>=1.0$ \\
\hline 1 & 34.2 & 14.7 & 24.4 & 1097.6 & 0.0 & 53.1 & -2.9 & 0 & 15 & 31 & 4 & 1.13 & 0.42 & 6.0 & 8.0 & 3 & 0 & 0 \\
\hline 2 & 29.5 & 11.8 & 20.5 & 1063.4 & 0.0 & 46.9 & -11.9 & $\underline{0}$ & 12 & 27 & 5 & 1.25 & 0.50 & 6.0 & 5.0 & 3 & 1 & 0 \\
\hline 3 & 43.5 & 23.9 & 33.6 & 813.2 & 0.0 & 62.1 & -4.0 & 0 & 2 & 27 & 1 & 1.04 & 0.53 & 0.5 & 2.0 & 3 & 1 & 0 \\
\hline 4 & 66.6 & 39.9 & 53.2 & 245.7 & 43.7 & 87.1 & 25.0 & 0 & 0 & 6 & 0 & 2.15 & 0.69 & 0.0 & 0.0 & 6 & 2 & 0 \\
\hline 5 & 72.7 & 52.2 & 62.4 & 58.5 & 133.7 & 91.9 & 45.0 & 3 & 0 & 0 & 0 & 8.85 & 2.02 & 0.0 & 0.0 & 8 & 5 & 4 \\
\hline 6 & 81.0 & 58.8 & 69.8 & 8.5 & 307.3 & 96.1 & 48.9 & 6 & 0 & 0 & 0 & 1.82 & 0.73 & 0.0 & 0.0 & 5 & 1 & 0 \\
\hline 7 & 88.5 & 67.3 & 77.9 & 0.0 & 558.2 & 99.0 & 55.0 & 15 & 0 & 0 & 0 & 0.87 & 0.60 & 0.0 & 0.0 & 2 & 1 & 0 \\
\hline 8 & 88.2 & 62.4 & 75.2 & 0.0 & 475.4 & 100.0 & 53.1 & 12 & 0 & 0 & 0 & 2.50 & 0.93 & 0.0 & 0.0 & 4 & 3 & 0 \\
\hline 9 & 77.2 & 51.4 & 64.4 & 37.3 & 170.6 & 93.0 & 35.1 & 3 & 0 & 0 & 0 & 2.90 & 1.50 & 0.0 & 0.0 & 5 & 2 & 1 \\
\hline 10 & 66.2 & 39.0 & 52.7 & 248.9 & 23.6 & 87.1 & 19.9 & 0 & 0 & 7 & 0 & 2.40 & 0.98 & 0.0 & 0.0 & 5 & 3 & 0 \\
\hline 11 & 61.7 & 36.3 & 48.9 & 333.4 & 5.4 & 77.0 & 21.0 & 0 & 3 & 12 & 0 & 2.21 & 1.58 & 0.0 & 0.0 & 3 & 1 & 1 \\
\hline 12 & 43.0 & 19.4 & 31.3 & 831.4 & 0.0 & 64.9 & 1.9 & 0 & 7 & 28 & 0 & 0.24 & 0.17 & 0.0 & 0.0 & 1 & 0 & 0 \\
\hline Summary & 62.7 & 39.8 & 51.2 & 4737.9 & 1717.9 & 100.0 & -11.9 & 39 & 39 & 138 & 10 & 27.36 & 2.02 & 12.5 & 8.0 & 48 & 20 & 6 \\
\hline
\end{tabular}


MONTHLY CLIMATOLOGICAL SUMMARY

2002
National Climatic Data Center Federal Building Asheville, North Carolina 28801

Station:GHCND:USC00255362, MEAD 6 S

Elev. 1154.86m. above sea leve

Lat. $41.143^{\circ}$, Lon. $-96.481^{\circ}$

\begin{tabular}{|c|c|c|c|c|c|c|c|c|c|c|c|c|c|c|c|c|c|c|}
\hline \multirow{2}{*}{\multicolumn{12}{|c|}{ Temperature(으) }} & & & & & & La. & 1. \\
\hline & & & & & & & & & & & & \multicolumn{7}{|c|}{ Precipitation(in.) } \\
\hline Elem-> & MMXT & MMNT & MNTM & HTDD & CLDD & EMXT & EMNT & DT90 & DX32 & DT32 & DT00 & TPCP & EMXP & TSNW & MXSD & DP01 & DP05 & DP10 \\
\hline \multirow[b]{2}{*}{$\begin{array}{l}2002 \\
\text { Month }\end{array}$} & \multirow[b]{2}{*}{$\begin{array}{l}\text { Mean } \\
\text { Max. }\end{array}$} & \multirow[b]{2}{*}{ Mean Min. } & \multirow[b]{2}{*}{ Mean } & \multirow{2}{*}{$\begin{array}{c}\text { Heating } \\
\text { Degree } \\
\text { Days }\end{array}$} & \multirow{2}{*}{$\begin{array}{c}\text { Cooling } \\
\text { Degree } \\
\text { Days }\end{array}$} & \multirow[b]{2}{*}{ Highest } & \multirow[b]{2}{*}{ Lowest } & \multicolumn{4}{|c|}{ Number Of Days } & \multirow[b]{2}{*}{ Total } & \multirow[b]{2}{*}{$\begin{array}{c}\text { Greatest } \\
\text { Observed }\end{array}$} & \multicolumn{2}{|c|}{ Snow, Sleet } & \multicolumn{3}{|c|}{ Number Of Days } \\
\hline & & & & & & & & Max $>=90^{\circ}$ & Max $<=32^{\circ}$ & Min $<=32^{\circ}$ & $\operatorname{Min}<=0^{\circ}$ & & & Total Fall & $\begin{array}{c}\text { Max } \\
\text { Depth }\end{array}$ & $>=.10$ & $>=.50$ & $>=1.0$ \\
\hline & 41.4 & 16.9 & 29.1 & 955.1 & 0.0 & 68.0 & 1.0 & 0 & 8 & 29 & 0 & 0.37 & 0.29 & 5.0 & 4.0 & & 0 & 0 \\
\hline 2 & 40.8 & 17.2 & 28.9 & 865.1 & 0.0 & 68.0 & -5.1 & 0 & 6 & 25 & 4 & 0.66 & 0.36 & 5.0 & 8.0 & 2 & 0 & 0 \\
\hline 3 & 45.1 & 20.5 & 33.3 & 772.6 & 0.0 & 64.9 & -4.0 & 0 & 4 & 27 & 2 & 0.88 & 0.36 & 7.0 & 3.0 & 3 & 0 & 0 \\
\hline 4 & 63.9 & 37.9 & 50.9 & 313.2 & 40.9 & 93.9 & 17.1 & 1 & 0 & 9 & 0 & 3.31 & 1.20 & 0.0 & 0.0 & 6 & 3 & 1 \\
\hline 5 & 71.4 & 45.3 & 58.5 & 134.5 & 88.6 & 91.0 & 35.1 & 1 & 0 & 0 & 0 & 3.29 & 1.18 & 0.0 & 0.0 & 7 & 2 & 1 \\
\hline 6 & 88.9 & 63.7 & 76.3 & 0.0 & 490.9 & 97.0 & 53.1 & 18 & 0 & 0 & 0 & 0.50 & 0.22 & 0.0 & 0.0 & 2 & 0 & 0 \\
\hline 7 & 92.1 & 66.7 & 79.3 & 0.0 & 604.1 & 102.0 & 57.9 & 23 & 0 & 0 & 0 & 2.52 & 1.53 & 0.0 & 0.0 & 6 & 1 & 1 \\
\hline 8 & 86.5 & 61.7 & 74.1 & 0.0 & 441.0 & 100.0 & 54.0 & 7 & 0 & 0 & 0 & 8.26 & 2.60 & 0.0 & 0.0 & 9 & 6 & 3 \\
\hline 9 & 78.8 & 52.5 & 65.7 & 32.4 & 198.5 & 93.0 & 42.1 & 6 & 0 & 0 & 0 & 1.33 & 0.69 & 0.0 & 0.0 & 3 & 1 & 0 \\
\hline 10 & 57.0 & 36.7 & 46.9 & 429.5 & 25.0 & 89.1 & 23.0 & 0 & 2 & 12 & 0 & 4.06 & 1.71 & 1.8 & 1.0 & 8 & 2 & 2 \\
\hline 11 & 48.4 & 23.9 & 36.1 & 713.2 & 0.0 & 72.0 & 1.9 & 0 & 4 & 24 & 0 & 0.26 & 0.16 & 2.9 & 3.0 & 2 & 0 & 0 \\
\hline 12 & 44.1 & 19.0 & 31.6 & 877.5 & 0.0 & 66.0 & 5.0 & 0 & 4 & 30 & 0 & 0.00 & 0.00 & 0.0 & 0.0 & 0 & 0 & 0 \\
\hline Summary & 63.2 & 38.5 & 50.9 & 5093.1 & 1889.0 & 102.0 & -5.1 & 56 & 28 & 156 & 6 & 25.44 & 2.60 & 21.7 & 8.0 & 49 & 15 & 8 \\
\hline
\end{tabular}


MONTHLY CLIMATOLOGICAL SUMMARY

2003
National Climatic Data Center Federal Building Asheville, North Carolina 28801

Station:GHCND:USC00255362, MEAD 6 S

Elev. 1154.86m. above sea level

Lat. $41.143^{\circ}$, Lon. $-96.481^{\circ}$

\begin{tabular}{|c|c|c|c|c|c|c|c|c|c|c|c|c|c|c|c|c|c|c|}
\hline \multirow{2}{*}{$\begin{array}{l}\text { Date } \\
\text { Elem-> }\end{array}$} & \multicolumn{11}{|c|}{ Temperature(으) } & \multicolumn{7}{|c|}{ Precipitation(in.) } \\
\hline & MMXT & MMNT & MNTM & HTDD & CLDD & EMXT & EMNT & DT90 & DX32 & DT32 & DT00 & TPCP & EMXP & TSNW & MXSD & DP01 & DP05 & DP10 \\
\hline \multirow{2}{*}{$\begin{array}{l}2003 \\
\text { Month }\end{array}$} & \multirow{2}{*}{$\begin{array}{l}\text { Mean } \\
\text { Max. }\end{array}$} & \multirow[b]{2}{*}{ Mean Min. } & \multirow[b]{2}{*}{ Mean } & \multirow{2}{*}{$\begin{array}{c}\text { Heating } \\
\text { Degree } \\
\text { Days }\end{array}$} & \multirow{2}{*}{$\begin{array}{c}\text { Cooling } \\
\text { Degree } \\
\text { Days }\end{array}$} & \multirow[b]{2}{*}{ Highest } & \multirow[b]{2}{*}{ Lowest } & \multicolumn{4}{|c|}{ Number Of Days } & \multirow[b]{2}{*}{ Total } & \multirow[b]{2}{*}{$\begin{array}{c}\text { Greatest } \\
\text { Observed }\end{array}$} & \multicolumn{2}{|c|}{ Snow, Sleet } & \multicolumn{3}{|c|}{ Number Of Days } \\
\hline & & & & & & & & Max $>=90^{\circ}$ & Max $<=32^{\circ}$ & Min $<=32^{\circ}$ & $\operatorname{Min}<=0^{\circ}$ & & & Total Fall & $\begin{array}{c}\text { Max } \\
\text { Depth }\end{array}$ & $>=.10$ & $>=.50$ & $>=1.0$ \\
\hline & 34.7 & 12.2 & 23.4 & 1130.6 & 0.0 & 69.1 & -13.0 & 0 & 16 & 31 & 4 & 0.42 & 0.30 & 7.5 & 6.0 & 1 & 0 & 0 \\
\hline 2 & 34.2 & 12.0 & 23.2 & 1030.1 & 0.0 & 55.0 & -6.0 & 0 & 13 & 28 & 5 & 1.00 & 0.76 & 5.5 & 3.0 & 2 & 1 & 0 \\
\hline 3 & 50.5 & 25.2 & 37.8 & 685.8 & 1.6 & 82.9 & 3.0 & 0 & 6 & 21 & 0 & 0.75 & 0.46 & 1.0 & 1.0 & 2 & 0 & 0 \\
\hline 4 & 64.6 & 39.9 & 52.3 & 281.2 & 52.9 & 90.0 & 21.9 & 1 & 2 & 7 & 0 & 2.87 & 1.08 & 4.0 & 4.0 & 6 & 2 & 1 \\
\hline 5 & 70.5 & 46.9 & 58.8 & 100.4 & 64.6 & 88.0 & 37.9 & 0 & 0 & 0 & 0 & 5.17 & 1.25 & 0.0 & 0.0 & 10 & 4 & 1 \\
\hline 6 & 78.6 & 57.6 & 68.2 & 16.2 & 262.4 & 91.0 & 48.0 & 2 & 0 & 0 & 0 & 4.05 & 1.15 & 0.0 & 0.0 & 9 & 2 & 1 \\
\hline 7 & 89.6 & 63.7 & 76.6 & 0.0 & 518.9 & 102.0 & 54.0 & 16 & 0 & 0 & 0 & 0.95 & 0.53 & 0.0 & 0.0 & 2 & 1 & 0 \\
\hline 8 & 90.0 & 63.3 & 76.6 & 0.0 & (519.5 & 102.9 & 57.0 & 13 & 0 & 0 & 0 & 1.70 & 0.81 & 0.0 & 0.0 & 4 & 1 & 0 \\
\hline 9 & 76.3 & 45.9 & 61.2 & 80.8 & 116.8 & 90.0 & 30.0 & 2 & 0 & 2 & 0 & 3.58 & 1.32 & 0.0 & 0.0 & 5 & 3 & 2 \\
\hline 10 & 69.1 & 39.9 & 54.5 & 231.8 & 66.2 & 87.1 & 30.0 & 0 & 0 & 7 & 0 & 1.72 & 0.98 & 0.0 & 0.0 & 3 & 2 & 0 \\
\hline 11 & 47.5 & 26.4 & 37.0 & \begin{tabular}{l|l}
641.7 \\
\end{tabular} & 0.0 & 73.0 & 9.0 & 0 & 1 & 20 & 0 & 2.83 & 1.42 & 0.3 & 0.0 & 5 & 2 & 1 \\
\hline 12 & 39.4 & 21.7 & 30.6 & 909.9 & $\begin{array}{l}0.0 \\
\end{array}$ & 64.0 & 1.9 & 0 & 7 & 29 & 0 & 0.59 & 0.33 & 4.0 & 4.0 & 2 & 0 & 0 \\
\hline Summary & 62.1 & 37.9 & 50.0 & 5108.5 & 1602.9 & 102.9 & -13.0 & 34 & 45 & 145 & 9 & 25.63 & 1.42 & 22.3 & 6.0 & 51 & 18 & 6 \\
\hline
\end{tabular}


MONTHLY CLIMATOLOGICAL SUMMARY

2004
National Climatic Data Center Federal Building Asheville, North Carolina 28801

Station:GHCND:USC00255362, MEAD 6 S

Elev. 1154.86m. above sea leve

Lat. $41.143^{\circ}$, Lon. $-96.481^{\circ}$

\begin{tabular}{|c|c|c|c|c|c|c|c|c|c|c|c|c|c|c|c|c|c|c|}
\hline \multirow{2}{*}{\multicolumn{12}{|c|}{ DIIOH. }} & & & & & & La. & 1. \\
\hline & & & & & & & & & & & & \multicolumn{7}{|c|}{ Precipitation(in.) } \\
\hline Elem-> & MMXT & MMNT & MNTM & HTDD & CLDD & EMXT & EMNT & DT90 & DX32 & DT32 & DT00 & TPCP & EMXP & TSNW & MXSD & DP01 & DP05 & DP10 \\
\hline \multirow[b]{2}{*}{$\begin{array}{l}2004 \\
\text { Month }\end{array}$} & \multirow[b]{2}{*}{$\begin{array}{l}\text { Mean } \\
\text { Max. }\end{array}$} & \multirow[b]{2}{*}{ Mean Min. } & \multirow[b]{2}{*}{ Mean } & \multirow{2}{*}{$\begin{array}{c}\text { Heating } \\
\text { Degree } \\
\text { Days }\end{array}$} & \multirow{2}{*}{$\begin{array}{c}\text { Cooling } \\
\text { Degree } \\
\text { Days }\end{array}$} & \multirow[b]{2}{*}{ Highest } & \multirow[b]{2}{*}{ Lowest } & \multicolumn{4}{|c|}{ Number Of Days } & \multirow[b]{2}{*}{ Total } & \multirow[b]{2}{*}{$\begin{array}{c}\text { Greatest } \\
\text { Observed }\end{array}$} & \multicolumn{2}{|c|}{ Snow, Sleet } & \multicolumn{3}{|c|}{ Number Of Days } \\
\hline & & & & & & & & Max $>=90^{\circ}$ & Max $<=32^{\circ}$ & Min $<=32^{\circ}$ & $\operatorname{Min}<=0^{\circ}$ & & & Total Fall & $\begin{array}{c}\text { Max } \\
\text { Depth }\end{array}$ & $>=.10$ & $>=.50$ & $>=1.0$ \\
\hline & 30.2 & 10.4 & 20.3 & 1226.2 & 0.0 & 63.0 & -11.0 & 0 & 17 & 31 & 8 & 0.98 & 0.49 & 16.0 & 11.0 & 3 & 0 & 0 \\
\hline 2 & 32.4 & 12.7 & 22.5 & 1084.1 & 0.0 & 55.9 & -9.9 & 0 & 14 & 26 & 6 & 0.64 & 0.35 & 8.0 & 19.0 & 3 & 0 & 0 \\
\hline 3 & 53.2 & 32.4 & 42.8 & 544.1 & 13.7 & 73.9 & 17.1 & 0 & 1 & 22 & 0 & 3.32 & 1.26 & 1.0 & 1.0 & 5 & 2 & 1 \\
\hline 4 & 66.6 & 37.9 & 52.2 & 253.6 & 30.4 & 89.1 & 23.0 & 0 & 0 & 8 & 0 & 0.99 & 0.85 & 0.0 & 0.0 & 1 & 1 & 0 \\
\hline 5 & 74.5 & 50.0 & 62.2 & 104.6 & 178.0 & 89.1 & 27.0 & 0 & 0 & 2 & 0 & 4.77 & 1.57 & 0.0 & 0.0 & 8 & 3 & 2 \\
\hline 6 & 77.9 & 56.5 & 67.3 & 8.8 & 228.2 & 89.1 & 44.1 & 0 & 0 & 0 & 0 & 3.09 & 2.00 & 0.0 & 0.0 & 8 & 1 & 1 \\
\hline 7 & 81.9 & 60.6 & 71.2 & 0.4 & 353.0 & 95.0 & 48.0 & 4 & 0 & 0 & 0 & 3.00 & 0.99 & 0.0 & 0.0 & 10 & 1 & 0 \\
\hline 8 & 82.6 & 56.3 & 69.4 & 2.9 & 298.6 & 97.0 & 46.0 & 5 & 0 & 0 & 0 & 1.93 & 0.92 & 0.0 & 0.0 & 5 & 2 & 0 \\
\hline 9 & 83.8 & 54.1 & 69.1 & 11.9 & 284.8 & 95.0 & 35.1 & 6 & 0 & 0 & 0 & 4.03 & 2.86 & 0.0 & 0.0 & 3 & 3 & 1 \\
\hline 10 & 67.6 & 41.4 & 54.5 & 193.1 & 24.8 & 82.0 & 28.0 & 0 & 0 & 5 & 0 & 0.86 & 0.26 & 0.0 & 0.0 & 4 & 0 & 0 \\
\hline 11 & 51.4 & 30.2 & 40.8 & 572.6 & 0.0 & 78.1 & 9.0 & 0 & 2 & 17 & 0 & 3.15 & 0.96 & 2.0 & 2.0 & 5 & 4 & 0 \\
\hline 12 & 40.5 & 17.1 & 28.8 & 963.4 & 0.0 & 66.0 & -4.0 & 0 & 6 & 31 & 4 & 0.31 & 0.31 & 0.0 & 0.0 & 1 & 0 & 0 \\
\hline Summary & 61.9 & 38.3 & 50.1 & 4965.7 & 1411.5 & 97.0 & -11.0 & 15 & 40 & 142 & 18 & 27.07 & 2.86 & 27.0 & 19.0 & 56 & 17 & 5 \\
\hline
\end{tabular}


MONTHLY CLIMATOLOGICAL SUMMARY

2005
National Climatic Data Center Federal Building Asheville, North Carolina 28801

Station:GHCND:USC00255362, MEAD 6 S

Elev. 1154.86m. above sea leve

Lat. $41.143^{\circ}$, Lon. $-96.481^{\circ}$

\begin{tabular}{|c|c|c|c|c|c|c|c|c|c|c|c|c|c|c|c|c|c|c|}
\hline \multirow{2}{*}{\multicolumn{12}{|c|}{ DIIOH. }} & & & & & & La. & 1. \\
\hline & & & & & & & & & & & & \multicolumn{7}{|c|}{ Precipitation(in.) } \\
\hline Elem-> & MMXT & MMNT & MNTM & HTDD & CLDD & EMXT & EMNT & DT90 & DX32 & DT32 & DT00 & TPCP & EMXP & TSNW & MXSD & DP01 & DP05 & DP10 \\
\hline \multirow[b]{2}{*}{$\begin{array}{l}2005 \\
\text { Month }\end{array}$} & \multirow[b]{2}{*}{$\begin{array}{l}\text { Mean } \\
\text { Max. }\end{array}$} & \multirow[b]{2}{*}{ Mean Min. } & \multirow[b]{2}{*}{ Mean } & \multirow{2}{*}{$\begin{array}{c}\text { Heating } \\
\text { Degree } \\
\text { Days }\end{array}$} & \multirow{2}{*}{$\begin{array}{c}\text { Cooling } \\
\text { Degree } \\
\text { Days }\end{array}$} & \multirow[b]{2}{*}{ Highest } & \multirow[b]{2}{*}{ Lowest } & \multicolumn{4}{|c|}{ Number Of Days } & \multirow[b]{2}{*}{ Total } & \multirow[b]{2}{*}{$\begin{array}{c}\text { Greatest } \\
\text { Observed }\end{array}$} & \multicolumn{2}{|c|}{ Snow, Sleet } & \multicolumn{3}{|c|}{ Number Of Days } \\
\hline & & & & & & & & Max $>=90^{\circ}$ & Max $<=32^{\circ}$ & Min $<=32^{\circ}$ & $\operatorname{Min}<=0^{\circ}$ & & & Total Fall & $\begin{array}{c}\text { Max } \\
\text { Depth }\end{array}$ & $>=.10$ & $>=.50$ & $>=1.0$ \\
\hline & 28.2 & 10.8 & 19.4 & 1253.2 & 0.0 & 57.0 & -15.0 & 0 & 18 & 31 & 8 & 0.95 & 0.40 & 8.0 & 7.0 & 3 & 0 & 0 \\
\hline 2 & 43.2 & 21.7 & 32.5 & 767.3 & 0.0 & 64.0 & 0.0 & 0 & 4 & 27 & 2 & 2.85 & 1.35 & 7.0 & 7.0 & 5 & 2 & 1 \\
\hline 3 & 52.5 & 25.7 & 39.2 & 626.2 & 4.1 & 78.1 & 10.0 & 0 & 1 & 24 & 0 & 0.66 & 0.19 & 0.0 & 0.0 & 3 & 0 & 0 \\
\hline 4 & 65.7 & 39.7 & 52.7 & 250.7 & 33.8 & 82.0 & 23.0 & 0 & 0 & 5 & 0 & 3.62 & 1.05 & 0.0 & 0.0 & 6 & 3 & 1 \\
\hline 5 & 73.8 & 47.3 & 60.4 & 114.3 & 133.6 & 89.1 & 30.0 & 0 & 0 & 4 & 0 & 2.74 & 1.98 & 0.0 & 0.0 & 4 & 1 & 1 \\
\hline 6 & 84.9 & 62.8 & 73.8 & 0.0 & 418.3 & 96.1 & 55.0 & 10 & 0 & 0 & 0 & 3.47 & 0.97 & 0.0 & 0.0 & 5 & 4 & 0 \\
\hline 7 & 90.7 & 64.2 & 77.4 & 0.0 & 543.6 & 102.9 & 50.0 & 19 & 0 & 0 & 0 & 3.97 & 2.80 & 0.0 & 0.0 & 3 & 2 & 1 \\
\hline 8 & 86.2 & 61.3 & 73.8 & 0.0 & 430.0 & 96.1 & 52.0 & 10 & 0 & 0 & 0 & 0.77 & 0.31 & 0.0 & 0.0 & 3 & 0 & 0 \\
\hline 9 & 85.5 & 53.8 & 69.6 & 3.4 & 295.6 & 99.0 & 30.9 & 11 & 0 & 2 & 0 & 0.99 & 0.62 & 0.0 & 0.0 & 3 & 1 & 0 \\
\hline 10 & 68.0 & 39.7 & 54.0 & 264.8 & 80.1 & 93.0 & 25.0 & 3 & 0 & 10 & 0 & 1.69 & 0.60 & 0.0 & 0.0 & 5 & 1 & 0 \\
\hline 11 & 54.5 & 29.1 & 41.7 & 543.6 & 0.7 & 80.1 & 8.1 & 0 & 3 & 18 & 0 & 1.15 & 0.59 & 0.6 & 1.0 & 3 & 1 & 0 \\
\hline 12 & 32.7 & 14.7 & 23.7 & 1123.0 & 0.0 & 57.9 & -8.0 & 0 & 14 & 30 & 7 & 1.02 & 0.35 & 5.5 & 5.0 & 4 & 0 & 0 \\
\hline Summary & 63.8 & 39.2 & 51.5 & 4946.5 & 1939.8 & 102.9 & -15.0 & 53 & 40 & 151 & 17 & 23.88 & 2.80 & 21.1 & 7.0 & 47 & 15 & 4 \\
\hline
\end{tabular}


MONTHLY CLIMATOLOGICAL SUMMARY

2006
National Climatic Data Center Federal Building Asheville, North Carolina 28801

Station:GHCND:USC00255362, MEAD 6 S

Elev. 1154.86m. above sea leve

Lat. $41.143^{\circ}$, Lon. $-96.481^{\circ}$

\begin{tabular}{|c|c|c|c|c|c|c|c|c|c|c|c|c|c|c|c|c|c|c|}
\hline \multirow{2}{*}{$\begin{array}{l}\text { Date } \\
\text { Elem-> }\end{array}$} & \multicolumn{11}{|c|}{ Temperature(으) } & \multicolumn{7}{|c|}{ Precipitation(in.) } \\
\hline & MMXT & MMNT & MNTM & HTDD & CLDD & EMXT & EMNT & DT90 & DX32 & DT32 & DT00 & TPCP & EMXP & TSNW & MXSD & DP01 & DP05 & DP10 \\
\hline \multirow[b]{2}{*}{$\begin{array}{l}2006 \\
\text { Month }\end{array}$} & \multirow[b]{2}{*}{$\begin{array}{l}\text { Mean } \\
\text { Max. }\end{array}$} & \multirow[b]{2}{*}{ Mean Min. } & \multirow[b]{2}{*}{ Mean } & \multirow{2}{*}{$\begin{array}{c}\text { Heating } \\
\text { Degree } \\
\text { Days }\end{array}$} & \multirow{2}{*}{$\begin{array}{c}\text { Cooling } \\
\text { Degree } \\
\text { Days }\end{array}$} & \multirow[b]{2}{*}{ Highest } & \multirow[b]{2}{*}{ Lowest } & \multicolumn{4}{|c|}{ Number Of Days } & \multirow[b]{2}{*}{ Total } & \multirow[b]{2}{*}{$\begin{array}{c}\text { Greatest } \\
\text { Observed }\end{array}$} & \multicolumn{2}{|c|}{ Snow, Sleet } & \multicolumn{3}{|c|}{ Number Of Days } \\
\hline & & & & & & & & Max $>=90^{\circ}$ & Max $<=32^{\circ}$ & Min $<=32^{\circ}$ & $\operatorname{Min}<=0^{\circ}$ & & & Total Fall & $\begin{array}{c}\text { Max } \\
\text { Depth }\end{array}$ & $>=.10$ & $>=.50$ & $>=1.0$ \\
\hline & 47.7 & 23.4 & 35.4 & 757.3 & 0.0 & 66.0 & 14.0 & 0 & 1 & 28 & 0 & 1.59 & 1.06 & 0.0 & 0.0 & 2 & 2 & \\
\hline 2 & 41.7 & 15.3 & 28.6 & 877.9 & 0.0 & 69.1 & -8.0 & 0 & 6 & 28 & 3 & 0.11 & 0.06 & 1.0 & 1.0 & 0 & 0 & ( \\
\hline 3 & 48.9 & 26.4 & 37.8 & 688.5 & 0.0 & 75.0 & 14.0 & 0 & 2 & 25 & 0 & 3.52 & 2.11 & 10.0 & 10.0 & 5 & 2 & - \\
\hline 4 & 68.5 & 41.2 & 54.9 & 201.1 & 49.3 & 87.1 & 30.0 & 0 & 0 & 6 & 0 & 4.21 & 1.27 & 0.0 & 0.0 & 9 & 2 & 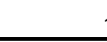 \\
\hline 5 & 75.0 & 50.4 & 62.8 & 74.0 & 161.8 & 91.9 & 39.9 & 4 & 0 & 0 & 0 & 1.38 & 0.68 & 0.0 & 0.0 & 4 & 1 & ( \\
\hline 6 & 86.4 & 59.9 & 73.2 & 0.0 & 384.1 & 98.1 & 50.0 & 8 & 0 & 0 & 0 & 0.97 & 0.33 & 0.0 & 0.0 & 3 & 0 & - \\
\hline 7 & 90.9 & 64.2 & 77.5 & 0.0 & 528.8 & 104.0 & 54.0 & 19 & 0 & 0 & 0 & 3.03 & 1.47 & 0.0 & 0.0 & 6 & 2 & 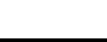 \\
\hline 8 & 84.9 & 63.0 & 73.9 & 0.0 & 4 & 102.0 & 53.1 & 7 & 0 & 0 & 0 & 6.14 & 2.37 & 0.0 & 0.0 & 10 & 4 & - \\
\hline 9 & 74.1 & 48.9 & 61.5 & 50.8 & 101.7 & 91.0 & 37.9 & 1 & 0 & 0 & 0 & 6.26 & 1.68 & 0.0 & 0.0 & 7 & 4 & 3 \\
\hline 10 & 63.0 & 37.8 & 50.4 & 358.9 & 63.0 & 91.9 & 21.9 & 3 & 0 & 14 & 0 & 0.77 & 0.15 & 0.0 & 0.0 & 5 & 0 & 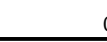 \\
\hline 11 & 54.5 & 25.5 & 39.9 & 601.0 & 3.6 & 84.0 & 9.0 & 0 & 1 & 25 & 0 & 0.20 & 0.14 & 0.0 & 0.0 & 1 & 0 & ( \\
\hline 12 & 43.9 & 20.3 & 32.2 & 860.8 & 0.0 & 60.1 & 1.9 & 0 & 4 & 29 & 0 & 2.17 & 1.09 & 1.0 & 1.0 & 3 & 2 & - \\
\hline Summary & 65.0 & 39.7 & 52.3 & 4470.3 & 1727.9 & 104.0 & -8.0 & 42 & 14 & 155 & 3 & 30.35 & 2.37 & 12.0 & 10.0 & 55 & 19 & 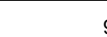 \\
\hline
\end{tabular}


MONTHLY CLIMATOLOGICAL SUMMARY

2007
National Climatic Data Center Federal Building Asheville, North Carolina 28801

Station:GHCND:USC00255362, MEAD 6 S

Elev. 1154.86m. above sea leve

Lat. $41.143^{\circ}$, Lon. $-96.481^{\circ}$

\begin{tabular}{|c|c|c|c|c|c|c|c|c|c|c|c|c|c|c|c|c|c|c|}
\hline Date & \multicolumn{11}{|c|}{ Temperature(ㅇF) } & \multicolumn{7}{|c|}{ Precipitation(in.) } \\
\hline Elem-> & MMXT & MMNT & MNTM & HTDD & CLDD & EMXT & EMNT & DT90 & $\mathrm{D} \times 32$ & DT32 & DT00 & TPCP & EMXP & TSNW & MXSD & DP01 & DP05 & DP10 \\
\hline \multirow{2}{*}{$\begin{array}{l}2007 \\
\text { Month }\end{array}$} & \multirow{2}{*}{$\begin{array}{l}\text { Mean } \\
\text { Max. }\end{array}$} & \multirow[b]{2}{*}{ Mean Min. } & \multirow[b]{2}{*}{ Mean } & \multirow{2}{*}{$\begin{array}{c}\text { Heating } \\
\text { Degree } \\
\text { Days }\end{array}$} & \multirow{2}{*}{$\begin{array}{c}\text { Cooling } \\
\text { Degree } \\
\text { Days }\end{array}$} & \multirow[b]{2}{*}{ Highest } & \multirow[b]{2}{*}{ Lowest } & \multicolumn{4}{|c|}{ Number Of Days } & \multirow[b]{2}{*}{ Total } & \multirow[b]{2}{*}{$\begin{array}{l}\text { Greatest } \\
\text { Observed }\end{array}$} & \multicolumn{2}{|c|}{ Snow, Sleet } & \multicolumn{3}{|c|}{ Number Of Days } \\
\hline & & & & & & & & $\operatorname{Max}>=90^{\circ}$ & Max $<=32^{\circ}$ & Min $<=32^{\circ}$ & $\operatorname{Min}<=0^{\circ}$ & & & Total Fall & $\begin{array}{l}\text { Max } \\
\text { Depth }\end{array}$ & $>=.10$ & $>=.50$ & $>=1.0$ \\
\hline 1 & 32.7 & 11.8 & 22.3 & 1129.0 & 0.0 & 52.0 & -14.1 & 0 & 12 & 29 & 6 & 0.53 & 0.35 & 8.0 & 6.0 & 2 & 0 & 0 \\
\hline 2 & 30.4 & 10.9 & 20.7 & 1097.3 & 0.0 & 57.9 & -8.0 & 0 & 13 & 27 & 8 & 1.83 & 0.94 & 7.3 & 3.0 & 6 & 1 & 0 \\
\hline 3 & 55.6 & 34.0 & 44.8 & 499.3 & 31.1 & 80.1 & 7.0 & 0 & 4 & 18 & 0 & 2.45 & 0.88 & 7.0 & 7.0 & 7 & 1 & 0 \\
\hline 4 & 61.0 & 36.9 & 48.9 & 356.9 & 28.4 & 88.0 & 15.1 & 0 & 0 & 11 & 0 & 4.65 & 2.10 & 0.0 & 0.0 & 6 & 3 & 2 \\
\hline 5 & 77.0 & 54.0 & 65.5 & 11.7 & 184.5 & 90.0 & 43.0 & 1 & 0 & 0 & 0 & 6.87 & 3.62 & 0.0 & 0.0 & 10 & 3 & 2 \\
\hline 6 & 83.7 & 59.5 & 71.6 & 0.0 & 351.2 & 91.9 & 50.0 & 4 & 0 & 0 & 0 & 2.46 & 1.21 & 0.0 & 0.0 & 5 & 2 & 1 \\
\hline 7 & 89.2 & 64.8 & 77.0 & 0.0 & 531.5 & 98.1 & 54.0 & 15 & 0 & 0 & 0 & 1.65 & 0.80 & 0.0 & 0.0 & 3 & 2 & 0 \\
\hline 8 & 87.6 & 66.6 & 77.0 & 0.0 & 532.6 & 96.1 & 55.0 & 14 & 0 & 0 & 0 & 10.15 & 2.21 & 0.0 & 0.0 & 12 & 7 & 5 \\
\hline 9 & 78.8 & 51.4 & 65.1 & 38.2 & 194.0 & 89.1 & 36.0 & 0 & 0 & 0 & 0 & 2.99 & 1.52 & 0.0 & 0.0 & 3 & 2 & 2 \\
\hline 10 & 69.1 & 43.5 & 56.3 & 169.4 & 59.2 & 87.1 & 28.0 & 0 & 0 & 6 & 0 & 4.75 & 1.43 & 0.0 & 0.0 & 9 & 3 & 1 \\
\hline 11 & 52.3 & 25.2 & 38.8 & 634.5 & 0.0 & 78.1 & 12.0 & 0 & 2 & 26 & 0 & 0.00 & 0.00 & 0.0 & 0.0 & 0 & 0 & 0 \\
\hline 12 & 30.9 & 11.3 & 21.0 & 1203.1 & 0.0 & 48.9 & -5.1 & 0 & 19 & 31 & 2 & 2.07 & 0.60 & 9.4 & 6.0 & 5 & 2 & 0 \\
\hline Summary & 62.4 & 39.2 & 50.8 & 5139.4 & 1912.5 & 98.1 & -14.1 & 34 & 50 & 148 & 16 & 40.40 & 3.62 & 31.7 & 7.0 & 68 & 26 & 13 \\
\hline
\end{tabular}


MONTHLY CLIMATOLOGICAL SUMMARY

2008
National Climatic Data Center Federal Building Asheville, North Carolina 28801

Station:GHCND:USC00255362, MEAD 6 S

Elev. 1154.86m. above sea leve

Lat. $41.143^{\circ}$, Lon. $-96.481^{\circ}$

\begin{tabular}{|c|c|c|c|c|c|c|c|c|c|c|c|c|c|c|c|c|c|c|}
\hline Date & \multicolumn{11}{|c|}{ Temperature(ㅇF) } & \multicolumn{7}{|c|}{ Precipitation(in.) } \\
\hline Elem-> & MMXT & MMNT & MNTM & HTDD & CLDD & EMXT & EMNT & DT90 & $\mathrm{D} \times 32$ & DT32 & DT00 & TPCP & EMXP & TSNW & MXSD & DP01 & DP05 & DP10 \\
\hline \multirow{2}{*}{$\begin{array}{l}2008 \\
\text { Month }\end{array}$} & \multirow{2}{*}{$\begin{array}{l}\text { Mean } \\
\text { Max. }\end{array}$} & \multirow[b]{2}{*}{ Mean Min. } & \multirow[b]{2}{*}{ Mean } & \multirow{2}{*}{$\begin{array}{c}\text { Heating } \\
\text { Degree } \\
\text { Days }\end{array}$} & \multirow{2}{*}{$\begin{array}{c}\text { Cooling } \\
\text { Degree } \\
\text { Days }\end{array}$} & \multirow[b]{2}{*}{ Highest } & \multirow[b]{2}{*}{ Lowest } & \multicolumn{4}{|c|}{ Number Of Days } & \multirow[b]{2}{*}{ Total } & \multirow[b]{2}{*}{$\begin{array}{c}\text { Greatest } \\
\text { Observed }\end{array}$} & \multicolumn{2}{|c|}{ Snow, Sleet } & \multicolumn{3}{|c|}{ Number Of Days } \\
\hline & & & & & & & & $\operatorname{Max}>=90^{\circ}$ & Max $<=32^{\circ}$ & Min $<=32^{\circ}$ & $\operatorname{Min}<=0^{\circ}$ & & & Total Fall & $\begin{array}{l}\text { Max } \\
\text { Depth }\end{array}$ & $>=.10$ & $>=.50$ & $>=1.0$ \\
\hline 1 & 28.6 & 8.8 & 18.3 & 1245.2 & 0.0 & 54.0 & -13.0 & 0 & 17 & 31 & 9 & 0.23 & 0.13 & 2.2 & 2.0 & 1 & 0 & 0 \\
\hline 2 & 31.3 & 11.1 & 21.2 & 1121.2 & 0.0 & 57.0 & -7.1 & 0 & 14 & 29 & 2 & 0.39 & 0.17 & 2.5 & 3.0 & 2 & 0 & 0 \\
\hline 3 & 49.3 & 23.0 & 36.1 & 737.1 & 0.0 & 70.0 & -0.9 & 0 & 3 & 26 & 1 & 0.65 & 0.37 & 0.0 & 0.0 & 3 & 0 & 0 \\
\hline 4 & 56.1 & 33.4 & 44.8 & 454.1 & 0.7 & 80.1 & 24.1 & 0 & 0 & 16 & 0 & 4.64 & 1.10 & 0.0 & 0.0 & 10 & 3 & 1 \\
\hline 5 & 70.7 & 46.2 & 58.5 & 118.8 & 75.2 & 88.0 & 35.1 & 0 & 0 & 0 & 0 & 5.96 & 1.60 & 0.0 & 0.0 & 11 & 4 & 2 \\
\hline 6 & 82.0 & 58.8 & 70.3 & 0.0 & 315.5 & 90.0 & 54.0 & 2 & 0 & 0 & 0 & 9.90 & 2.50 & 0.0 & 0.0 & 7 & 6 & 4 \\
\hline 7 & 85.8 & 62.8 & 74.3 & 0.0 & 447.7 & 93.9 & 50.0 & 4 & 0 & 0 & 0 & 3.74 & 1.93 & 0.0 & 0.0 & 4 & 2 & 2 \\
\hline 8 & 84.9 & 59.4 & 72.1 & 0.0 & 378.0 & 98.1 & 50.0 & 4 & 0 & 0 & 0 & 1.01 & 0.57 & 0.0 & 0.0 & 3 & 1 & 0 \\
\hline 9 & 76.3 & 50.9 & 63.5 & 47.3 & 156.4 & 91.9 & 39.0 & 2 & 0 & 0 & 0 & 4.33 & 1.12 & 0.0 & 0.0 & 10 & 3 & 1 \\
\hline 10 & 64.8 & 39.2 & 52.0 & 278.1 & 34.4 & 82.0 & 21.0 & 0 & 0 & 5 & 0 & 5.06 & 1.75 & 0.0 & 0.0 & 6 & 5 & 1 \\
\hline 11 & 50.5 & 28.0 & 39.2 & 631.4 & 11.9 & 78.1 & 10.0 & 0 & 0 & 21 & 0 & 1.78 & 0.54 & 0.0 & 0.0 & 4 & 3 & 0 \\
\hline 12 & 31.3 & 11.8 & 21.6 & 1149.5 & 0.0 & 57.9 & -11.0 & 0 & 15 & 29 & 5 & $\begin{array}{l}1.19 \\
\end{array}$ & 0.62 & 9.1 & 4.0 & 4 & 1 & 0 \\
\hline Summary & 59.3 & 36.1 & 47.7 & 5782.7 & 1419.8 & 98.1 & -13.0 & 12 & 49 & 157 & 17 & 38.88 & 2.50 & 13.8 & 4.0 & 65 & 28 & 11 \\
\hline
\end{tabular}


MONTHLY CLIMATOLOGICAL SUMMARY

2009
National Climatic Data Center Federal Building Asheville, North Carolina 28801

Station:GHCND:USC00255362, MEAD 6 S

Elev. 1154.86m. above sea leve

Lat. $41.143^{\circ}$, Lon. $-96.481^{\circ}$

\begin{tabular}{|c|c|c|c|c|c|c|c|c|c|c|c|c|c|c|c|c|c|c|}
\hline \multirow{2}{*}{\multicolumn{12}{|c|}{ DIIOH. }} & & & & & & La. & 1. \\
\hline & & & & & & & & & & & & \multicolumn{7}{|c|}{ Precipitation(in.) } \\
\hline Elem-> & MMXT & MMNT & MNTM & HTDD & CLDD & EMXT & EMNT & DT90 & DX32 & DT32 & DT00 & TPCP & EMXP & TSNW & MXSD & DP01 & DP05 & DP10 \\
\hline \multirow[b]{2}{*}{$\begin{array}{l}2009 \\
\text { Month }\end{array}$} & \multirow[b]{2}{*}{$\begin{array}{l}\text { Mean } \\
\text { Max. }\end{array}$} & \multirow[b]{2}{*}{ Mean Min. } & \multirow[b]{2}{*}{ Mean } & \multirow{2}{*}{$\begin{array}{c}\text { Heating } \\
\text { Degree } \\
\text { Days }\end{array}$} & \multirow{2}{*}{$\begin{array}{c}\text { Cooling } \\
\text { Degree } \\
\text { Days }\end{array}$} & \multirow[b]{2}{*}{ Highest } & \multirow[b]{2}{*}{ Lowest } & \multicolumn{4}{|c|}{ Number Of Days } & \multirow[b]{2}{*}{ Total } & \multirow[b]{2}{*}{$\begin{array}{c}\text { Greatest } \\
\text { Observed }\end{array}$} & \multicolumn{2}{|c|}{ Snow, Sleet } & \multicolumn{3}{|c|}{ Number Of Days } \\
\hline & & & & & & & & Max $>=90^{\circ}$ & Max $<=32^{\circ}$ & Min $<=32^{\circ}$ & $\operatorname{Min}<=0^{\circ}$ & & & Total Fall & $\begin{array}{c}\text { Max } \\
\text { Depth }\end{array}$ & $>=.10$ & $>=.50$ & $>=1.0$ \\
\hline & 32.9 & 9.7 & 21.2 & 1197.5 & 0.0 & 55.0 & -13.0 & 0 & 11 & 31 & 8 & 0.27 & 0.08 & 5.3 & 2.0 & 0 & 0 & 0 \\
\hline 2 & 43.7 & 16.7 & 30.2 & 831.4 & 0.0 & 64.0 & 3.0 & 0 & 7 & 26 & 0 & 0.47 & 0.22 & 9.0 & 5.0 & 2 & 0 & 0 \\
\hline 3 & 50.4 & 24.1 & 37.2 & 705.8 & 1.1 & 78.1 & -2.0 & 0 & 5 & 25 & 3 & 0.32 & 0.13 & 0.0 & 4.0 & 2 & 0 & 0 \\
\hline 4 & 61.0 & 34.2 & 47.7 & 388.3 & 18.5 & 89.1 & 19.0 & 0 & 0 & 14 & 0 & 1.63 & 0.55 & 0.0 & 0.0 & 6 & 1 & 0 \\
\hline 5 & 74.3 & 48.0 & 61.2 & 72.7 & 110.3 & 90.0 & 37.9 & 1 & 0 & 0 & 0 & 1.10 & 0.92 & 0.0 & 0.0 & 1 & 1 & 0 \\
\hline 6 & 81.1 & 59.0 & 70.0 & 4.9 & 308.7 & 98.1 & 46.9 & 4 & 0 & 0 & 0 & 6.49 & 2.03 & 0.0 & 0.0 & 11 & 3 & 3 \\
\hline 7 & 80.6 & 58.6 & 69.4 & 0.0 & 288.9 & 89.1 & 50.0 & 0 & 0 & 0 & 0 & 2.62 & 1.39 & 0.0 & 0.0 & 5 & 1 & 1 \\
\hline 8 & 81.5 & 57.7 & 69.6 & 4.3 & 307.1 & 97.0 & 43.0 & 5 & 0 & 0 & 0 & 7.28 & 2.80 & 0.0 & 0.0 & 8 & 6 & 2 \\
\hline 9 & 75.4 & 50.5 & 63.0 & 34.2 & 126.2 & 82.0 & 36.0 & 0 & 0 & 0 & 0 & 1.55 & 0.86 & 0.0 & 0.0 & 2 & 2 & 0 \\
\hline 10 & 54.3 & 35.2 & 44.8 & 470.3 & 0.0 & 72.0 & 25.0 & 0 & 0 & 15 & 0 & 4.35 & 1.25 & 2.0 & 2.0 & 8 & 4 & 1 \\
\hline 11 & 55.9 & 30.4 & 43.2 & 502.7 & 0.0 & 73.0 & 18.0 & 0 & 0 & 18 & 0 & 0.00 & 0.00 & 0.0 & 0.0 & 0 & 0 & 0 \\
\hline 12 & 28.4 & 9.5 & 19.0 & 1267.7 & 0.0 & 60.1 & -7.1 & 0 & 23 & 31 & 6 & 2.65 & 0.83 & 23.0 & 15.0 & 5 & 2 & 0 \\
\hline Summary & 60.0 & 36.1 & 48.0 & 5479.8 & 1160.8 & 98.1 & -13.0 & 10 & 46 & 160 & 17 & 28.73 & 2.80 & 39.3 & 15.0 & 50 & 20 & 7 \\
\hline
\end{tabular}


MONTHLY CLIMATOLOGICAL SUMMARY

2010
National Climatic Data Center Federal Building Asheville, North Carolina 28801

Station:GHCND:USC00255362, MEAD 6 S

Elev. 1154.86m. above sea level

Lat. $41.143^{\circ}$, Lon. $-96.481^{\circ}$

\begin{tabular}{|c|c|c|c|c|c|c|c|c|c|c|c|c|c|c|c|c|c|c|}
\hline \multirow{2}{*}{\multicolumn{12}{|c|}{ DIIOH. }} & & & & & & La. & 1. \\
\hline & & & & & & & & & & & & \multicolumn{7}{|c|}{ Precipitation(in.) } \\
\hline Elem-> & MMXT & MMNT & MNTM & HTDD & CLDD & EMXT & EMNT & DT90 & DX32 & DT32 & DT00 & TPCP & EMXP & TSNW & MXSD & DP01 & DP05 & DP10 \\
\hline \multirow[b]{2}{*}{$\begin{array}{l}2010 \\
\text { Month }\end{array}$} & \multirow[b]{2}{*}{$\begin{array}{l}\text { Mean } \\
\text { Max. }\end{array}$} & \multirow[b]{2}{*}{ Mean Min. } & \multirow[b]{2}{*}{ Mean } & \multirow{2}{*}{$\begin{array}{c}\text { Heating } \\
\text { Degree } \\
\text { Days }\end{array}$} & \multirow{2}{*}{$\begin{array}{c}\text { Cooling } \\
\text { Degree } \\
\text { Days }\end{array}$} & \multirow[b]{2}{*}{ Highest } & \multirow[b]{2}{*}{ Lowest } & \multicolumn{4}{|c|}{ Number Of Days } & \multirow[b]{2}{*}{ Total } & \multirow[b]{2}{*}{$\begin{array}{c}\text { Greatest } \\
\text { Observed }\end{array}$} & \multicolumn{2}{|c|}{ Snow, Sleet } & \multicolumn{3}{|c|}{ Number Of Days } \\
\hline & & & & & & & & Max $>=90^{\circ}$ & Max $<=32^{\circ}$ & Min $<=32^{\circ}$ & $\operatorname{Min}<=0^{\circ}$ & & & Total Fall & $\begin{array}{c}\text { Max } \\
\text { Depth }\end{array}$ & $>=.10$ & $>=.50$ & $>=1.0$ \\
\hline & 21.9 & 7.9 & 14.9 & 1394.6 & 0.0 & 42.1 & -16.1 & 0 & 24 & 31 & 9 & 0.91 & 0.38 & 6.3 & 19.0 & 3 & 0 & 0 \\
\hline 2 & 27.1 & 11.5 & 19.2 & 1137.6 & 0.0 & 35.1 & -4.0 & 0 & 21 & 28 & 6 & 0.68 & 0.41 & 6.1 & 6.0 & & 0 & 0 \\
\hline 3 & 47.8 & 28.4 & 38.1 & 677.7 & 2.2 & 75.9 & 12.0 & 0 & 2 & 20 & 0 & 1.63 & 0.52 & 1.0 & 2.0 & 5 & 1 & 0 \\
\hline 4 & 68.5 & 41.4 & 55.0 & 187.2 & 38.7 & 84.9 & 28.0 & 0 & 0 & 6 & 0 & 4.03 & 1.17 & 0.0 & 0.0 & 8 & 3 & 1 \\
\hline 5 & 70.5 & 48.0 & 59.2 & 134.1 & 113.4 & 88.0 & 36.0 & 0 & 0 & 0 & 0 & 2.66 & 0.72 & 0.0 & 0.0 & 8 & 2 & 0 \\
\hline 6 & 83.1 & 60.4 & 71.8 & 0.0 & 345.4 & 93.0 & 48.9 & 4 & 0 & 0 & 0 & 9.83 & 2.04 & 0.0 & 0.0 & 14 & 7 & 3 \\
\hline 7 & 85.3 & 65.3 & 75.2 & 0.0 & 475.2 & 95.0 & 57.0 & 7 & 0 & 0 & 0 & 7.22 & 3.10 & 0.0 & 0.0 & 8 & 5 & 2 \\
\hline 8 & 88.0 & 63.3 & 75.6 & 0.0 & 487.1 & 98.1 & 52.0 & 12 & 0 & 0 & 0 & 2.51 & 0.86 & 0.0 & 0.0 & 4 & 3 & 0 \\
\hline 9 & 77.9 & 53.2 & 65.5 & 26.6 & 195.5 & 93.0 & 43.0 & 2 & 0 & 0 & 0 & 5.84 & 2.60 & 0.0 & 0.0 & 7 & 5 & 1 \\
\hline 10 & 71.1 & 38.8 & 55.0 & 173.7 & 22.0 & 91.0 & 27.0 & 1 & 0 & 5 & 0 & 0.23 & 0.23 & 0.0 & 0.0 & 1 & 0 & 0 \\
\hline 11 & 50.5 & 26.2 & 38.5 & 643.0 & 0.0 & 73.9 & 10.9 & 0 & 2 & 24 & 0 & 1.93 & 0.98 & 0.0 & 0.0 & 2 & 2 & 0 \\
\hline 12 & 33.4 & 14.2 & 23.7 & 1120.7 & 0.0 & 60.1 & 0.0 & 0 & 19 & 31 & 1 & 0.33 & 0.23 & 2.6 & 2.0 & 1 & 0 & 0 \\
\hline Summary & 60.4 & 38.2 & 49.3 & 5495.2 & 1679.5 & 98.1 & -16.1 & 26 & 68 & 145 & 16 & 37.80 & 3.10 & 16.0 & 19.0 & 62 & 28 & 7 \\
\hline
\end{tabular}


MONTHLY CLIMATOLOGICAL SUMMARY

2011
National Climatic Data Center Federal Building Asheville, North Carolina 28801

Station:GHCND:USC00255362, MEAD 6 S

Elev. 1154.86m. above sea leve

Lat. $41.143^{\circ}$, Lon. $-96.481^{\circ}$

\begin{tabular}{|c|c|c|c|c|c|c|c|c|c|c|c|c|c|c|c|c|c|c|}
\hline \multirow{2}{*}{$\begin{array}{l}\text { Date } \\
\text { Elem-> }\end{array}$} & \multicolumn{11}{|c|}{ Temperature(요 $\mathrm{F})$} & \multicolumn{7}{|c|}{ Precipitation(in.) } \\
\hline & MMXT & MMNT & MNTM & HTDD & CLDD & EMXT & EMNT & DT90 & DX32 & DT32 & DT00 & TPCP & EMXP & TSNW & MXSD & DP01 & DP05 & DP10 \\
\hline \multirow[b]{2}{*}{$\begin{array}{l}2011 \\
\text { Month }\end{array}$} & \multirow[b]{2}{*}{$\begin{array}{l}\text { Mean } \\
\text { Max. }\end{array}$} & \multirow[b]{2}{*}{ Mean Min. } & \multirow[b]{2}{*}{ Mean } & \multirow{2}{*}{$\begin{array}{c}\text { Heating } \\
\text { Degree } \\
\text { Days }\end{array}$} & \multirow{2}{*}{$\begin{array}{c}\text { Cooling } \\
\text { Degree } \\
\text { Days }\end{array}$} & \multirow[b]{2}{*}{ Highest } & \multirow[b]{2}{*}{ Lowest } & \multicolumn{4}{|c|}{ Number Of Days } & \multirow[b]{2}{*}{ Total } & \multirow[b]{2}{*}{$\begin{array}{c}\text { Greatest } \\
\text { Observed }\end{array}$} & \multicolumn{2}{|c|}{ Snow, Sleet } & \multicolumn{3}{|c|}{ Number Of Days } \\
\hline & & & & & & & & Max $>=90^{\circ}$ & Max $<=32^{\circ}$ & Min $<=32^{\circ}$ & $\operatorname{Min}<=0^{\circ}$ & & & Total Fall & $\begin{array}{c}\text { Max } \\
\text { Depth }\end{array}$ & $>=.10$ & $>=.50$ & $>=1.0$ \\
\hline 1 & 26.6 & 7.3 & 17.1 & 1330.7 & 0.0 & 48.9 & -9.9 & 0 & 19 & 31 & 7 & 0.91 & 0.35 & 15.6 & 13.0 & 3 & 0 & 0 \\
\hline 2 & 35.6 & 14.2 & 25.0 & 979.9 & 0.0 & 69.1 & -7.1 & 0 & 12 & 27 & 5 & 0.30 & 0.10 & 3.0 & 5.0 & 1 & 0 & 0 \\
\hline 3 & 48.9 & 25.2 & 37.0 & 709.6 & 0.0 & 77.0 & 10.9 & 0 & 1 & 27 & 0 & 0.59 & 0.27 & 4.0 & 3.0 & 3 & 0 & 0 \\
\hline 4 & 61.7 & 36.9 & 49.3 & 326.3 & 7.4 & 87.1 & 28.9 & 0 & 0 & 10 & 0 & 3.22 & 1.13 & 0.0 & 0.0 & 5 & 3 & 1 \\
\hline 5 & 72.9 & 47.8 & 60.4 & 112.1 & 126.5 & 96.1 & 32.0 & 2 & 0 & 1 & 0 & 7.61 & 2.72 & 0.0 & 0.0 & 8 & 6 & 3 \\
\hline 6 & 81.5 & 59.7 & 70.7 & 0.9 & 311.8 & 98.1 & 52.0 & 3 & 0 & 0 & 0 & 5.57 & 1.65 & 0.0 & 0.0 & 7 & 4 & 3 \\
\hline 7 & 89.1 & 68.9 & 79.0 & 0.0 & 592.0 & 98.1 & 63.0 & 14 & 0 & 0 & 0 & $\begin{array}{r}3.32 \\
\end{array}$ & 0.60 & 0.0 & 9999 & 11 & 2 & 0 \\
\hline 8 & 83.7 & 62.6 & 73.2 & 0.0 & 410.9 & 99.0 & 55.0 & 6 & 0 & 0 & 0 & 5.47 & 1.20 & 9999 & 9999 & 10 & 5 & 2 \\
\hline 9 & 74.3 & 46.8 & 60.4 & 88.0 & 106.2 & 93.9 & 34.0 & 2 & 0 & 0 & 0 & 0.89 & 0.48 & 9999 & 9999 & 3 & 0 & 0 \\
\hline 10 & 69.8 & 39.2 & 54.5 & 229.7 & 61.4 & 91.0 & 25.0 & 1 & 0 & 9 & 0 & 0.84 & 0.30 & 9999 & 9999 & 3 & 0 & 0 \\
\hline 11 & 52.5 & 25.2 & 38.8 & 632.9 & 0.0 & 72.0 & 10.9 & 0 & 0 & 26 & 0 & 1.43 & 0.80 & 0.0 & 0.0 & 2 & 2 & 0 \\
\hline Summary & 63.3 & 39.4 & 51.4 & 4410.1 & 1616.2 & 99.0 & -9.9 & 28 & 32 & 131 & 12 & 30.15 & 2.72 & 22.6 & 13.0 & 56 & 22 & 9 \\
\hline
\end{tabular}

